\title{
Annual Site Environmental Report
} January-D ecember 2001

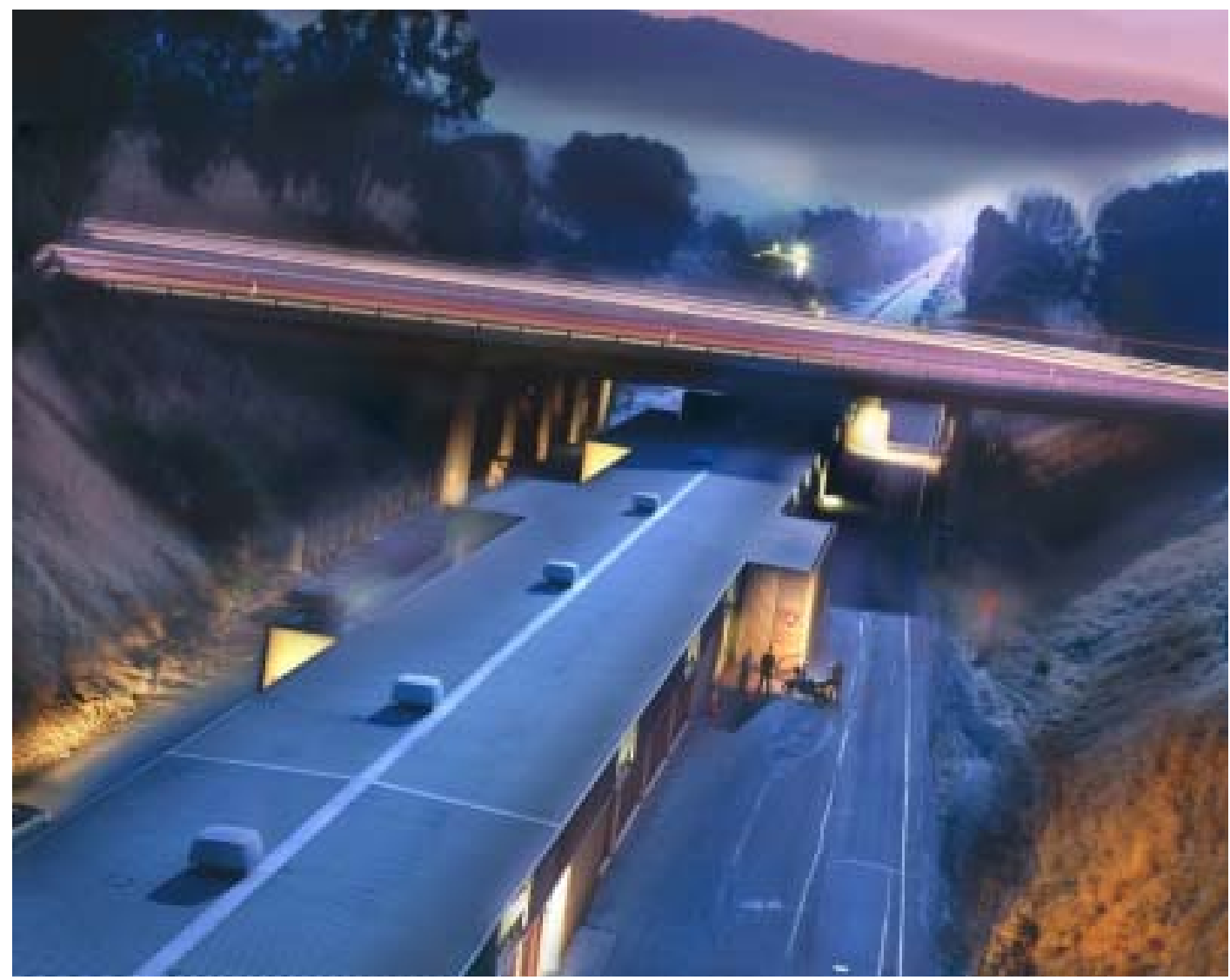

Prepared for the D epartment of Energy, under contract number DE-AC03-76SF00515

Environment, Safety, and Health D ivision

May 2003

\section{STAN FO RD LIN EAR ACCELERATO R CENTER}


This document and the material and data contained therein, was developed under sponsorship of the U nited States G overnment. N either the U nited States nor the Department of Energy, nor the Leland Stanford Junior University, nor their employees, makes any warranty, express or implied, or assumes any liability or responsibility for accuracy, completeness or usefulness of any information, apparatus, product or process disclosed, or represents that its use will not infringe privately-owned rights. Mention of any product, its manufacturer, or suppliers shall not, nor is it intended to, imply approval, disapproval, or fitness for any particular use. A royalty-free, non-exclusive right to use and disseminate same for any purpose whatsoever, is expressly reserved to the U nited States and the U niversity. 
SLAC-R-601

Site Environmental Report

(January-December 2001)

Environment, Safety, and Health Division

SLAC Report 601

May 2003

Prepared for the Department of Energy, under contract number DE-AC03-76SF00515

STANFORD LINEAR ACCELERATOR CENTER Stanford University Stanford, California 

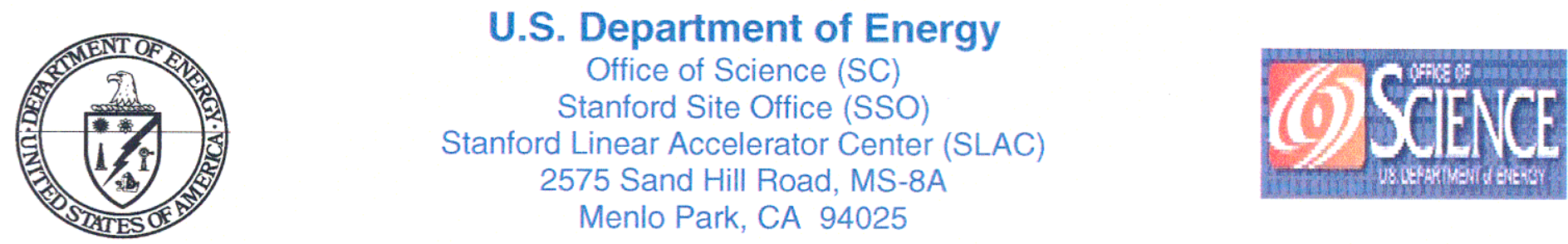

Irene Boczek

ES\&H Division

Stanford Linear Accelerator Center

2575 Sand Hill Road

Menlo Park, CA 94025

Subject: 2001 Annual Site Environmental Report (ASER) for the Stanford Linear Accelerator Center

This report, prepared by the Stanford Linear Accelerator Center (SLAC) for the U.S. Department of Energy (DOE), Stanford Site Office (SSO), provides a comprehensive summary of the environmental program activities at SLAC for calendar year 2001. Annual Site Environmental Reports (ASERs) are prepared for all DOE sites with significant environmental activities and distributed to relevant external regulatory agencies and other interested organizations or individuals.

To the best of my knowledge, this report accurately summarizes the results of the 2001 environmental monitoring, compliance, and restoration program at SLAC. This assurance can be made based on DOE and SLAC review of the ASER, and quality assurance protocols applied to monitoring and data analyses at SLAC. You are requested to make ASER distribution as identified in the subject report.

A reader survey form is provided with the ASER to provide comments or suggestions for future versions of the report. Your response is appreciated. Questions or comments regarding this report may also be made directly to DOE, by contacting Mr. Charles Lee of the SSO at (650) 926-8573, or by mail to the address above.

Attachment

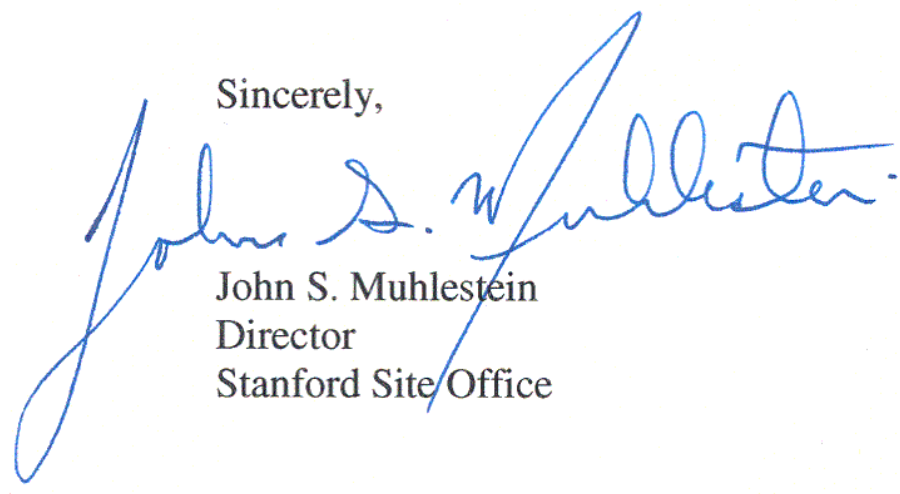




\section{Certification of Accuracy}

Annual Site Environmental Report

January - December 2001

SLAC-R-601

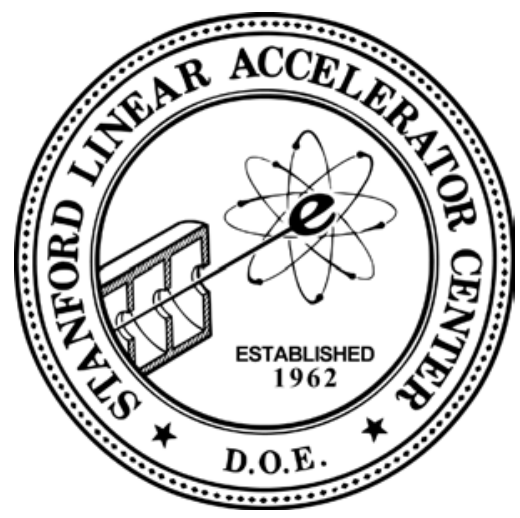

Stanford Linear Accelerator Center

I certify that the information submitted herein is current for the reporting period, accurate, and complete, based on my familiarity with the information and my inquiry of those individuals immediately responsible for obtaining the information.

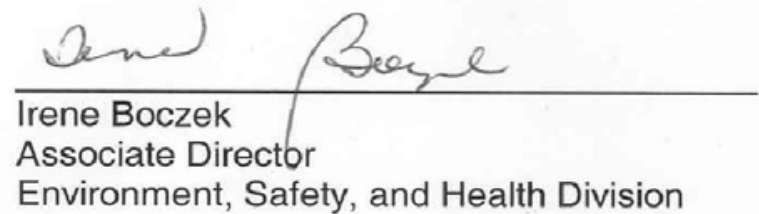

Date $01130 / 03$

Environment, Safety, and Health Division 


\section{Authors}

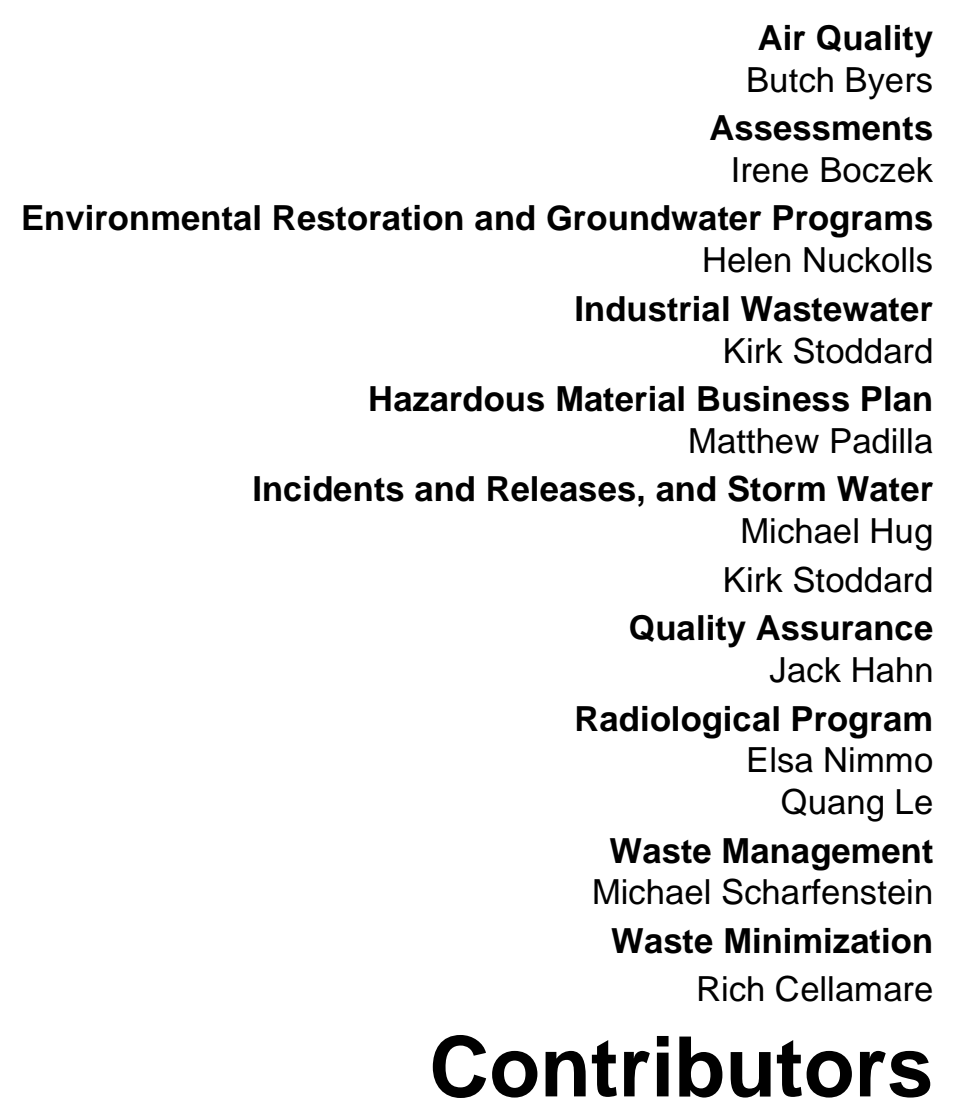

Graphics, Illustrations, Maps, and Publication

Terry Anderson

Michelle Decamara

Dellilah Sabba

Crystal Tilghman

Sharon West

Susan Witebsky

Larissa Williams

Coordinator

Hillary Russak

Editors

Hillary Russak

Larissa Williams 


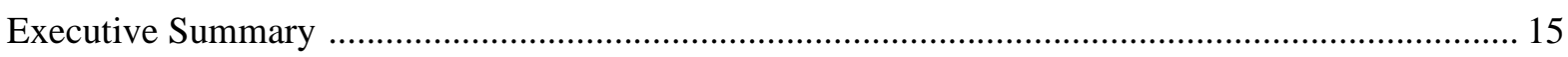

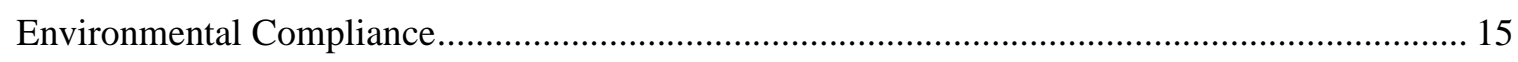

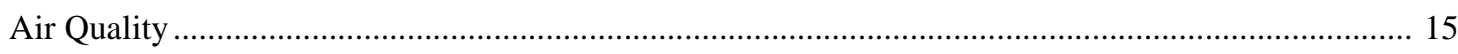

Industrial Wastewater …………………………………………………………………… 15

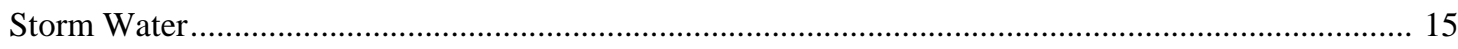

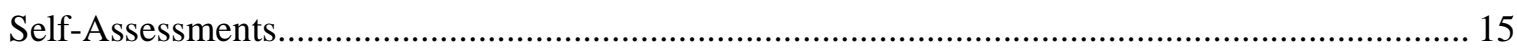

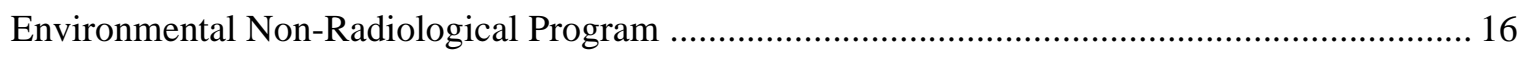

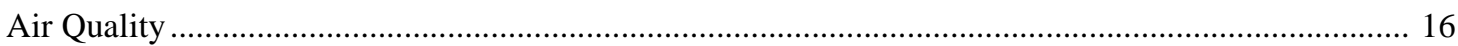

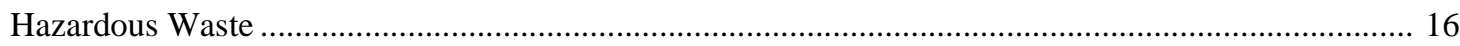

Storm Water and Industrial Wastewater...................................................................................... 16

Environmental Radiological Program ................................................................................ 16

Radiological Monitoring and Results .............................................................................................. 16

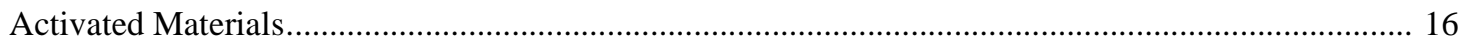

Groundwater Protection and Environmental Restoration …………………………………... 16

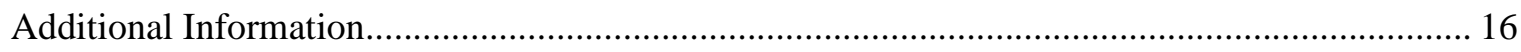

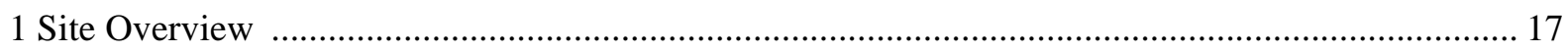

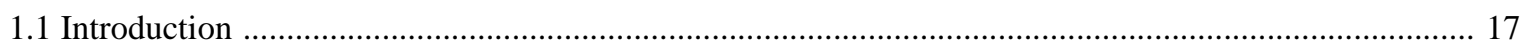

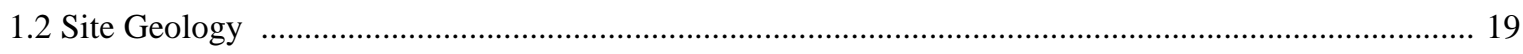

1.3 Local Climate ……………………………………………………………………………..... 19

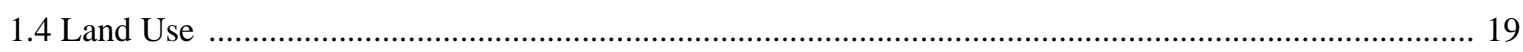

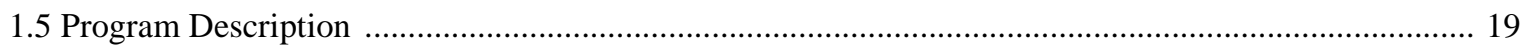

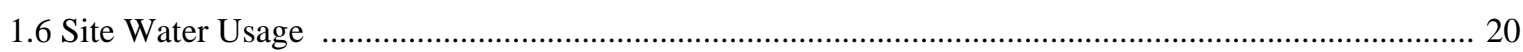

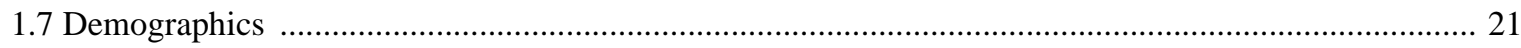

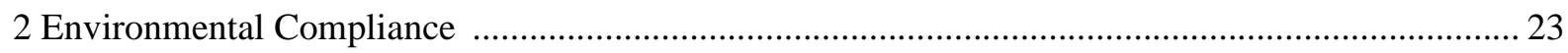

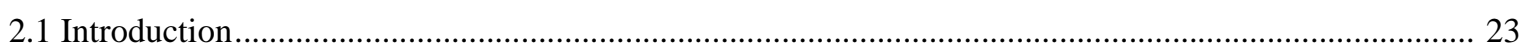

2.2 Environmental Management System .................................................................................................... 23

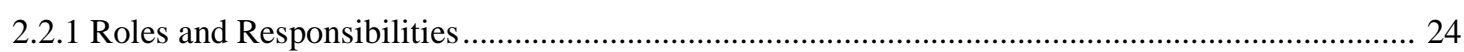

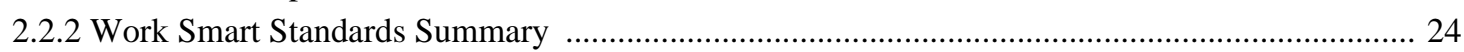

2.2.3 Safety Management System Summary ........................................................................................ 24

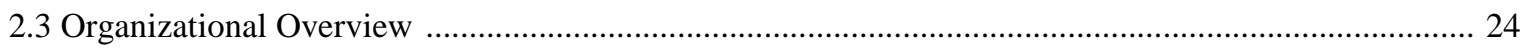

2.3.1 Environmental Protection and Restoration (EPR) …………………………………………….... 24

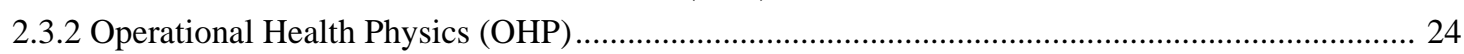

2.3.3 Radiation Physics (RP) ....................................................................................................... 24

2.3.4 Safety, Health, and Assurance (SHA) ……………………………………………………... 25

2.3.5 Waste Management (WM) ………………………………………………………………... 25 


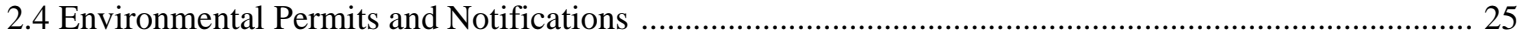

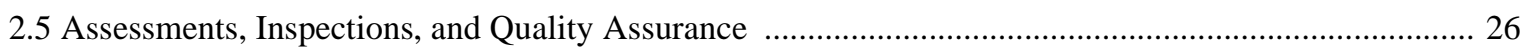

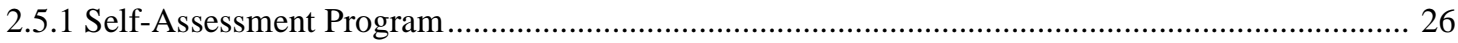

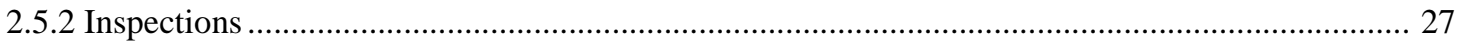

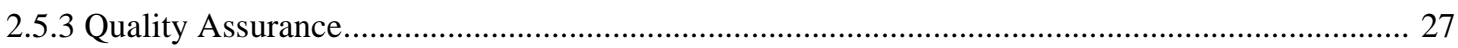

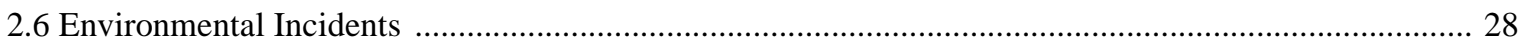

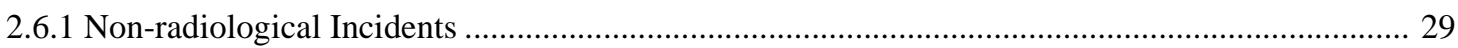

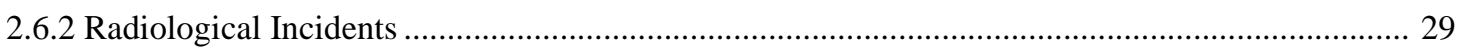

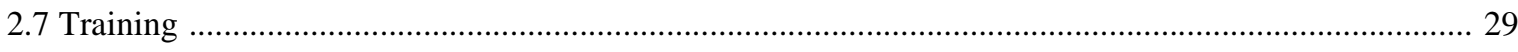

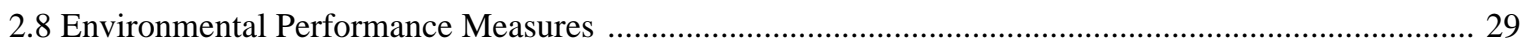

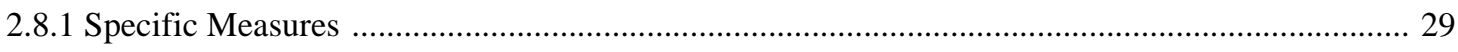

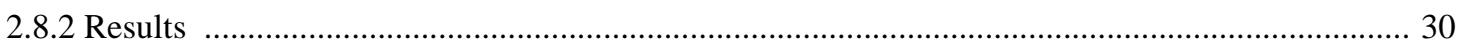

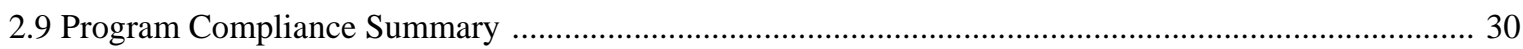

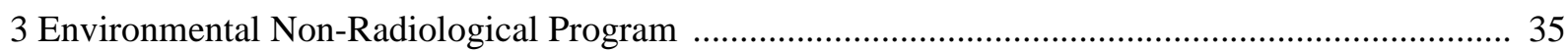

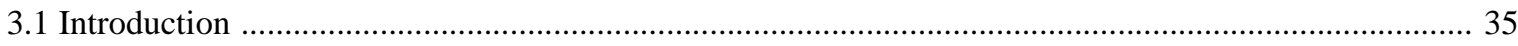

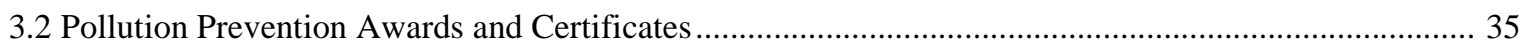

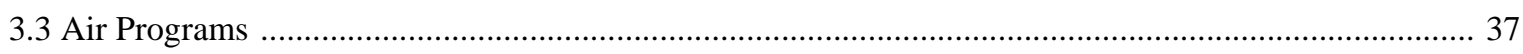

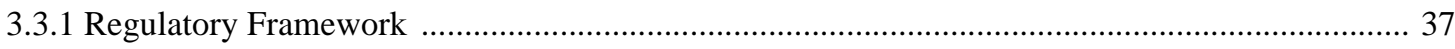

3.3.2 Bay Area Air Quality Management District-Implemented Programs ........................................ 38

3.3.3 United States Environmental Protection Agency-Implemented Programs .................................. 41

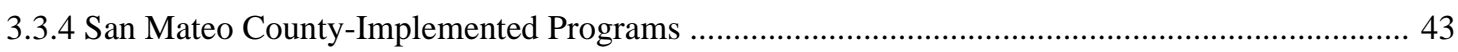

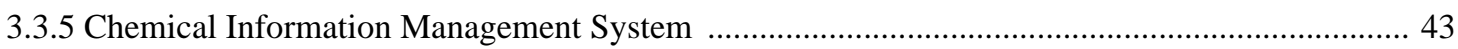

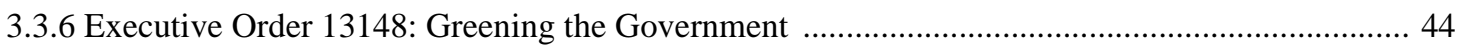

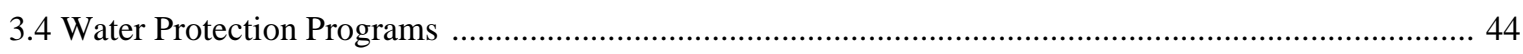

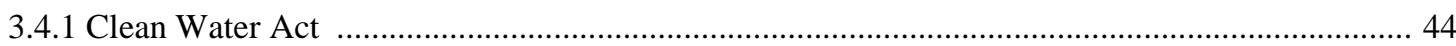

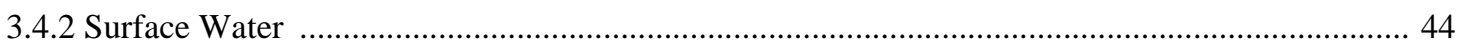

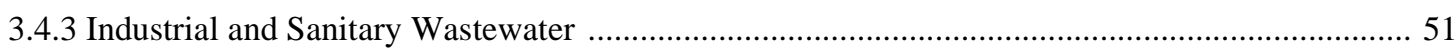

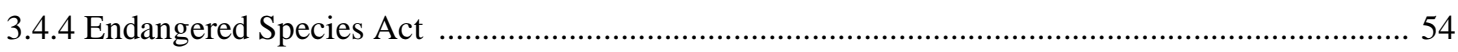

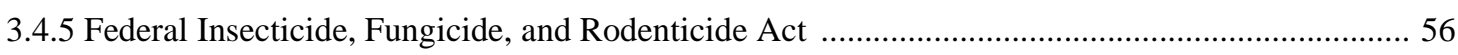

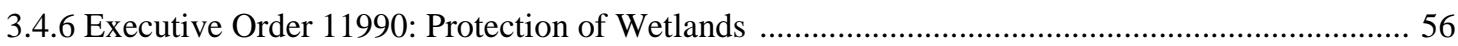

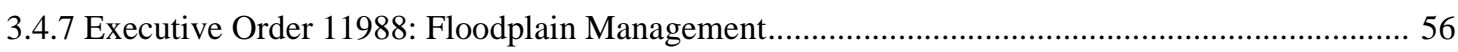

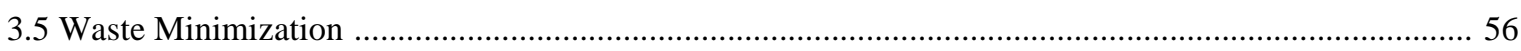

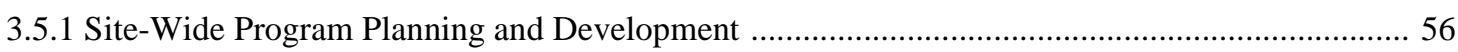

3.5.2 Waste Minimization and Pollution Prevention Activities and Implementation .............................. 57

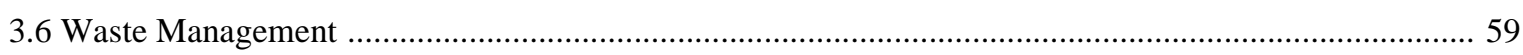

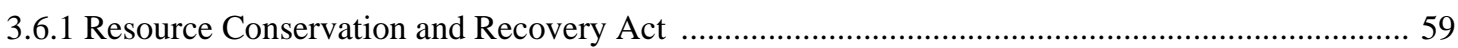

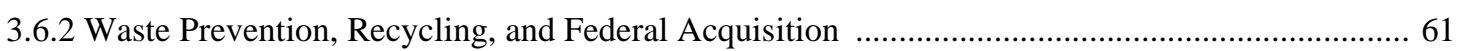

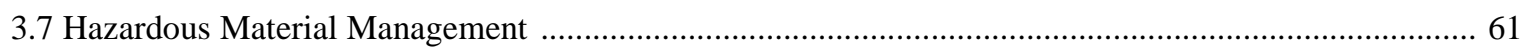

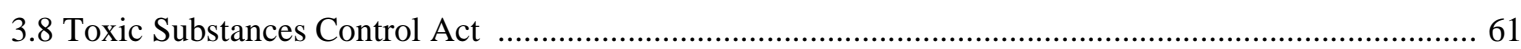

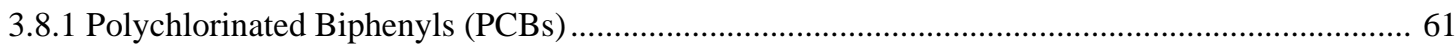

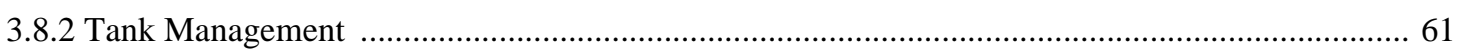

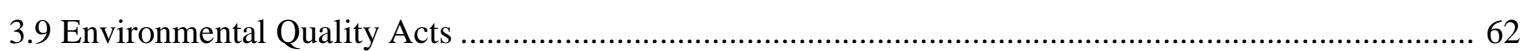

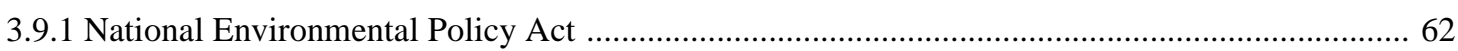

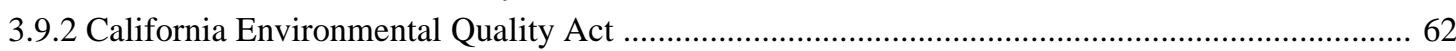




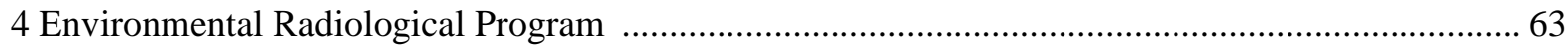

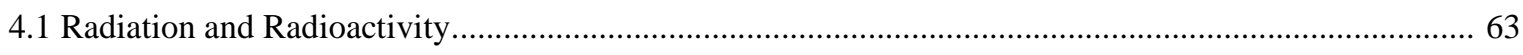

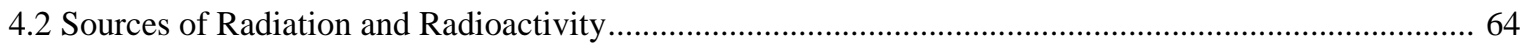

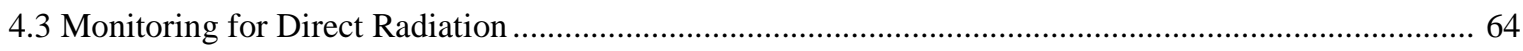

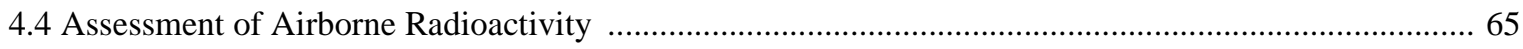

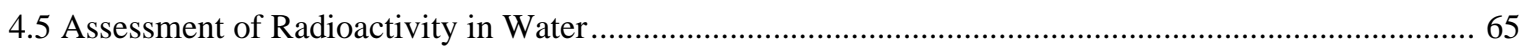

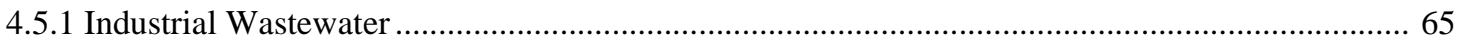

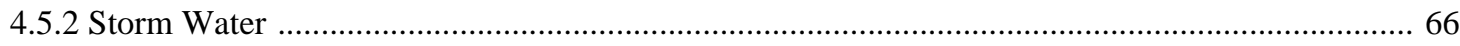

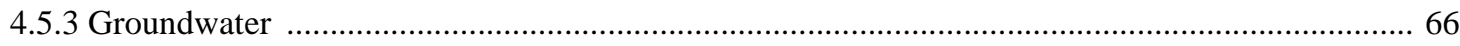

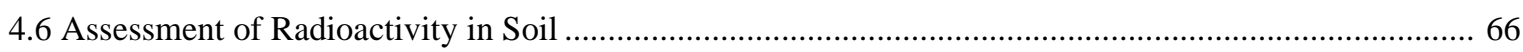

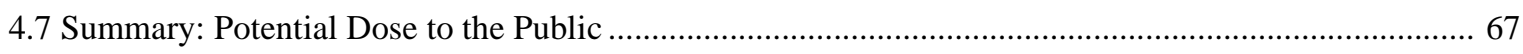

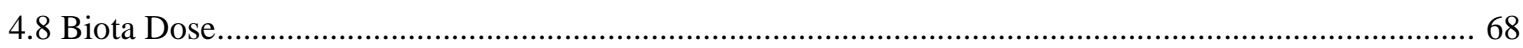

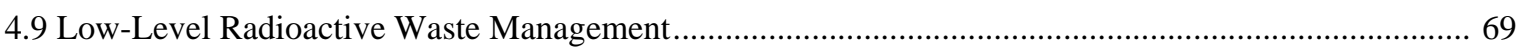

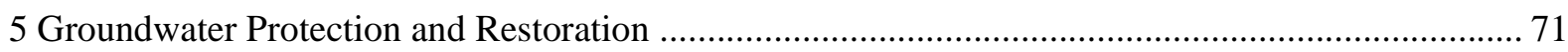

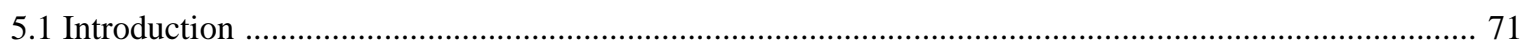

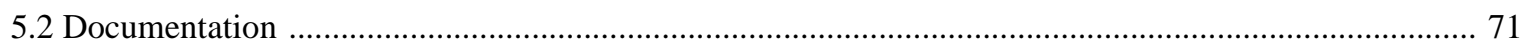

5.3 Identification and Summary of Areas with Potential Chemical Impact ................................................. 72

5.4 Strategies for Controlling Potential Sources of Chemicals ................................................................ 72

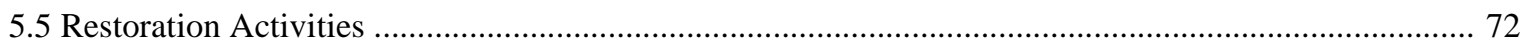

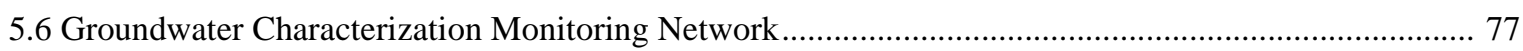

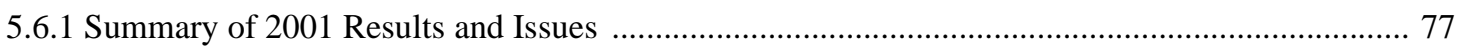

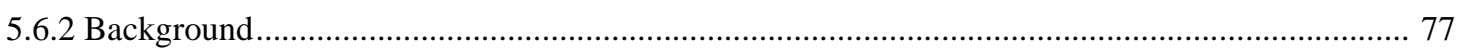

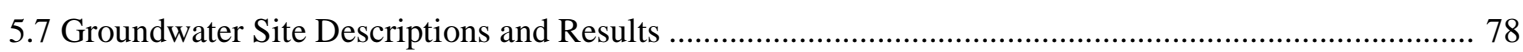

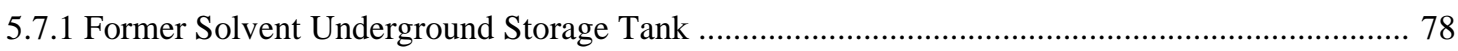

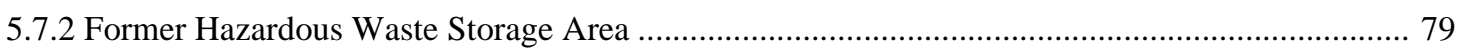

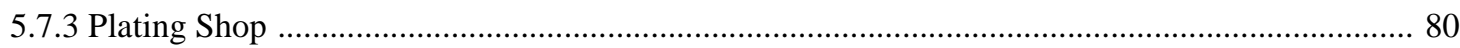

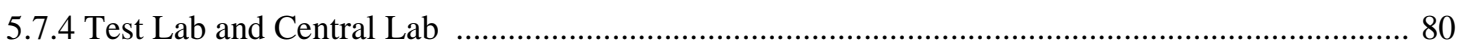

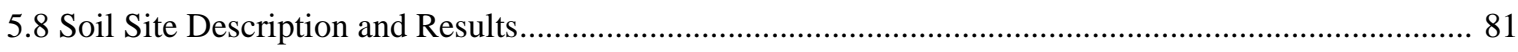

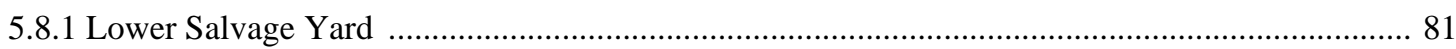

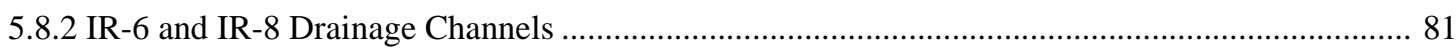

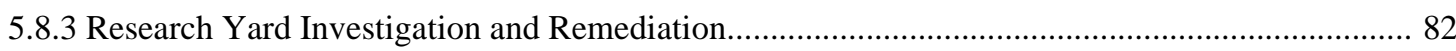

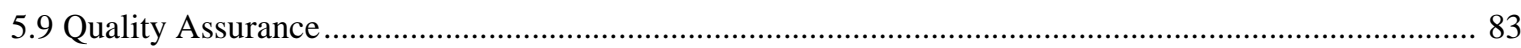

Appendices

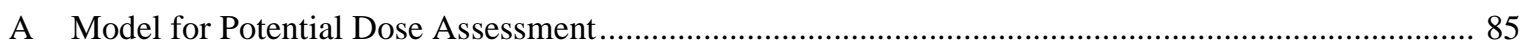

B Radionuclide Air Emissions Annual Report (NESHAPs Report) ………............................................ 89

C Environmental Dosimeter Measurements for 2001 .......................................................................... 107

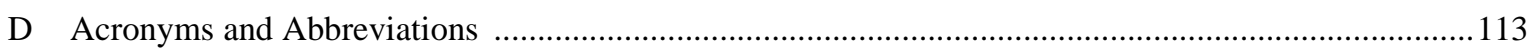

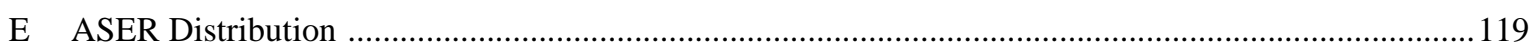

ASER Reader Survey 
Figures

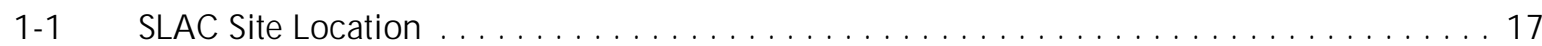

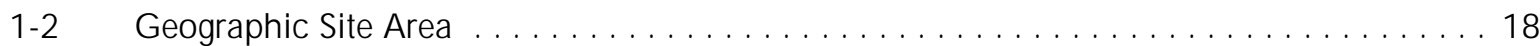

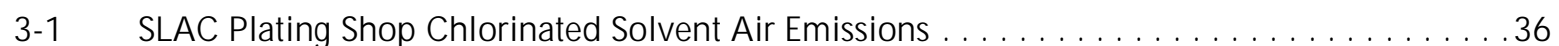

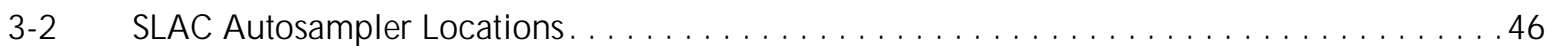

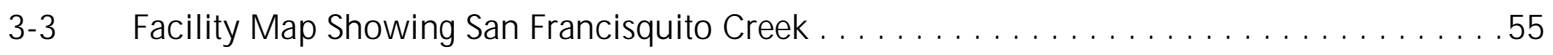

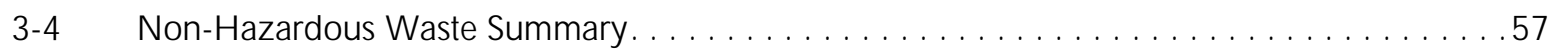

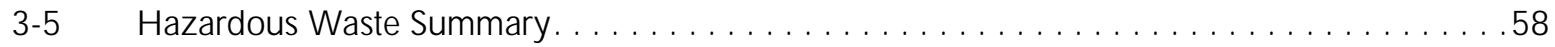

4-1 Annual Total Dose from SLAC and from $N$ atural Background $\ldots \ldots \ldots \ldots \ldots \ldots$

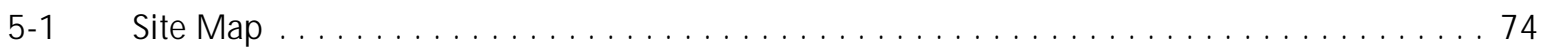

5-2 Location of W estern Groundwater Monitoring W ell N etwork and Areas with $\mathrm{G}$ roundwater Contamination . . . . . . . . . . . . . . . . . . . . . . . 75

5-3 Location of Eastern Groundwater M onitoring W ell N etwork and

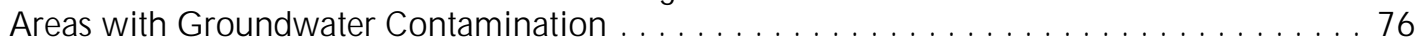

A-1 Neutron Measurements Made Along a Line Between End Station A and the

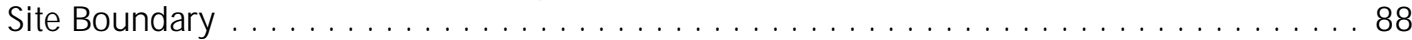

C-1 Environmental O SLD Monitoring Stations, Sector 27 through SLC $\ldots \ldots \ldots \ldots \ldots$

C-2 Environmental O SLD Monitoring Stations, Sectors 12 through $27 \ldots \ldots \ldots \ldots \ldots \ldots 110$

C-3 Environmental O SLD Monitoring Stations, S Sectors 0 through $12 \ldots \ldots \ldots \ldots \ldots \ldots 11$ 


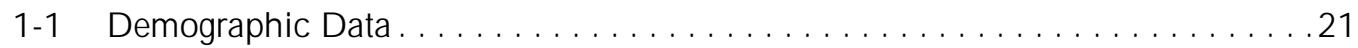

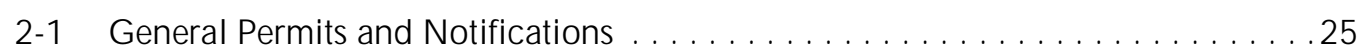

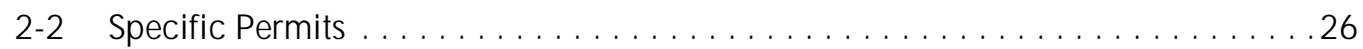

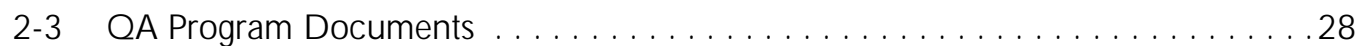

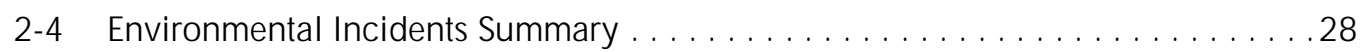

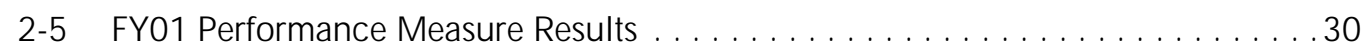

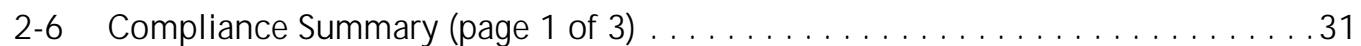

2-6 Compliance Summary (page 2 of 3 ) $\ldots \ldots \ldots \ldots \ldots \ldots \ldots \ldots \ldots \ldots \ldots \ldots \ldots \ldots$

2-6 Compliance Summary $(($ page 3 of 3$) \ldots \ldots \ldots \ldots \ldots \ldots \ldots \ldots \ldots \ldots \ldots \ldots \ldots$

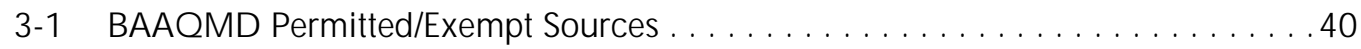

3-2 Storm W ater Data for 2001-2002 Sampling and Analysis (part 1 of 4) . . . . . . . 47

3-3 Storm W ater Data for 2001-2002 Sampling and Analysis (part 2 of 4). . . . . . . . 48

3-4 Storm W ater Data for 2001-2002 Sampling and Analysis (part 3 of 4). . . . . . . 49

3-5 Storm W ater Data for 2001-2002 Sampling and Analysis (part 3 of 4). . . . . . . 50

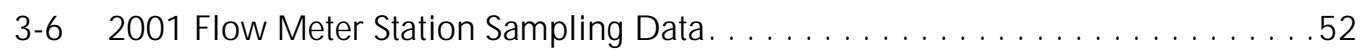

3-7 2001 Rinse W ater Treatment Plant Sampling D ata . . . . . . . . . . . . . . 53

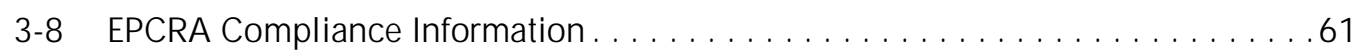

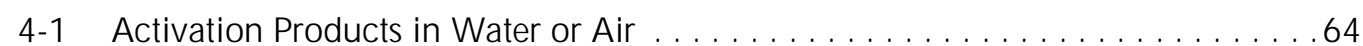

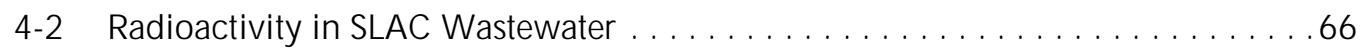

4-3 Summary of Annual D oses due to SLAC O perations in $2001 \ldots \ldots \ldots \ldots$

4-4 1995 - 2001 Summary of Calculated D ose to MEl from O perations at SLAC . . . . 67

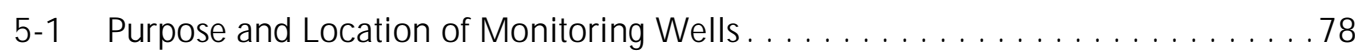




\section{Appendix B (NESHAPs)}

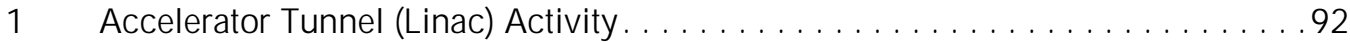

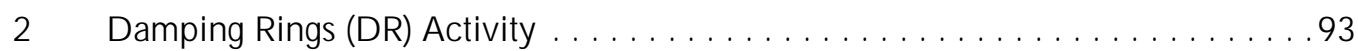

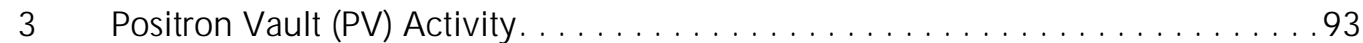

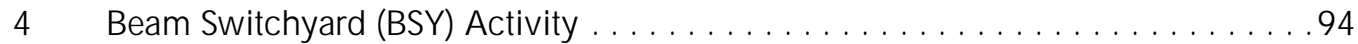

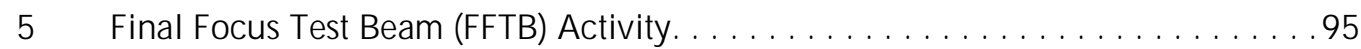

6 End Station A / Beam D ump East (ESA / BD E) Activity. . . . . . . . . . . . . . . . . . . 95

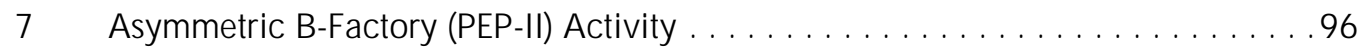

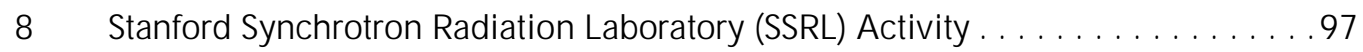

$9 \quad$ Next Linear Collider Test Accelerator (NLCTA) Activity . . . . . . . . . . . . . . . . . 97

10 Summary of CY01 EDE and CEDE due to Estimated Releases of Airborne Radioactivity . . . . . . . . . . . . . . 99

11 Summary of Estimated Activity Released for CY01 . . . . . . . . . . . . . 102

12 Determination of M aximally Exposed Individual. . . . . . . . . . . . 103 - 105

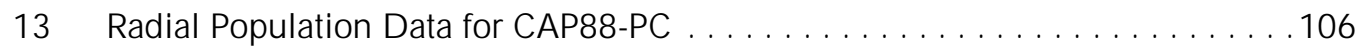

\section{Appendix C}

C-1 Summary of $\mathrm{N}$ et Photon and N eutron D oses for $2001 \ldots \ldots \ldots$

C-2 Environmental Dosimeters - N et Annual Doses for 2001 . . . . . . . . . . . . . . 107 


\section{Executive Summary}

This report provides information about environmental programs during 2001 at the Stanford Linear Accelerator Center (SLAC). Also included are seasonal activities that cross calendar-year divisions.

Production of the annual site environmental report (ASER) is a requirement established by the US Department of Energy (DOE) for all management and operating (M\&O) contractors throughout the DOE complex. SLAC is federally-funded, research development center with Stanford University as the M\&O contractor.

The most noteworthy information in this report is summarized in this section. This summary demonstrates the effective application of SLAC environmental management in meeting the site's Integrated Safety Management System (ISMS) goals. For normal daily activities, all SLAC managers and supervisors are responsible for ensuring that proper procedures are followed to meet the ISMS goals:

- Worker safety and health are protected.

- The environment is protected.

- Compliance is assured.

Throughout 2001, SLAC focused on these activities through the SLAC management systems. These systems were also the ways SLAC approached implementing the "Greening of the Government" initiatives (such as Executive Order 13148). The management systems at SLAC are effective, supporting compliance with all relevant statutory and regulatory requirements. SLAC did not receive any notices of violation during 2001. In addition, many improvements were continued during 2001, including improvements in the storm drain system, improved ground water monitoring capabilities, and enhancements to the system to manage the generation of mixed wastes. Environmental program-specific summary details are shown below.

\section{Environmental Compliance}

Chapter 2 contains detailed Environmental Compliance and Assessments information. The following are highlights:

\section{Air Quality}

No notices of violation (NOVs) or notices to comply (NTCs) were received from the Bay Area Air Quality Management District (BAAQMD) during 2001.

\section{Industrial Wastewater}

No wastewater discharge permit violations occurred during 2001.

\section{Storm Water}

Three water releases that entered the storm-drain system resulted in notification to the Regional Water Quality Control Board (RWQCB) and the San Mateo County Health Department (SMCHD). No actions were taken by these regulatory agencies.

\section{Self-Assessments}

SLAC held its sixth annual safety and environmental standdown in April of 2001. The discussions provided employees with the opportunity to raise safety and environmental concerns. The standdown program included three choices: 
$\mathrm{T} \quad$ (Talk) = Traditional safety and environmental discussions.

$\mathrm{W}$ (Walk) = A walk-through inspection.

C $($ Clean $)=$ A site-wide clean-up program.

An overview of the SLAC assessment process and the results are provided in the 2001 Self-Assessment Report (see Sections III and IV). Self-assessments are intermittently supported by independent quality assurance audits.

\section{Environmental Non-Radiological Program}

Chapter 3 contains the bulk of the environmental non-radiological information.

\section{Air Quality}

A total of 25 air emission sources were included in the SLAC Permit to Operate from the Bay Area Air Quality Management District (BAAQMD) at year-end. No instances of non-compliance were noted. Our information indicated that all permitted emission sources were operated in compliance with their respective emissions limitations in 2001.

\section{Hazardous Waste}

SLAC implemented programs and systems designed to ensure compliance with all waste management requirements for non-radioactive hazardous waste in 2001. No notices of violation (NOVs) were issued for this program.

\section{Storm Water and Industrial Wastewater}

SLAC implemented programs and systems; and it expanded its Storm Water Monitoring Program to ensure continued compliance with the Storm Water General Permit. Based on an annual inspection and monitoring performed by SLAC and by the South Bayside System Authority (SBSA), SLAC continued to meet the requirements of all three wastewater discharge permits.

\section{Environmental Radiological Program}

Chapter 4 provides detailed information on the SLAC environmental radiological program.

\section{Radiological Monitoring and Results}

In 2001, no radiological incidents occurred that increased radiation levels or released radioactivity to the environment. In addition to managing its radioactive wastes safely and responsibly, SLAC worked to reduce the amount of generated waste. As detailed in Chapter 4, SLAC implemented programs and systems designed to show that, throughout 2001, SLAC was in compliance with all radiological requirements related to the environment.

\section{Groundwater Protection and Environmental Restoration}

Chapter 5 contains the bulk of the information about the groundwater protection and environmental restoration program. In general, environmental concerns at SLAC are limited in number, small in scale and are actively being managed or eliminated. The Environmental Restoration Program continued work on site characterization and evaluation of remedial alternatives at four sites with volatile organic compounds (VOCs) in groundwater and several areas with polychlorinated biphenyls and lead in soil.

\section{Additional Information}

A reader's survey has been provided at the end of this document.

Additional information about SLAC is available at:

http://www.slac.stanford.edu/ 


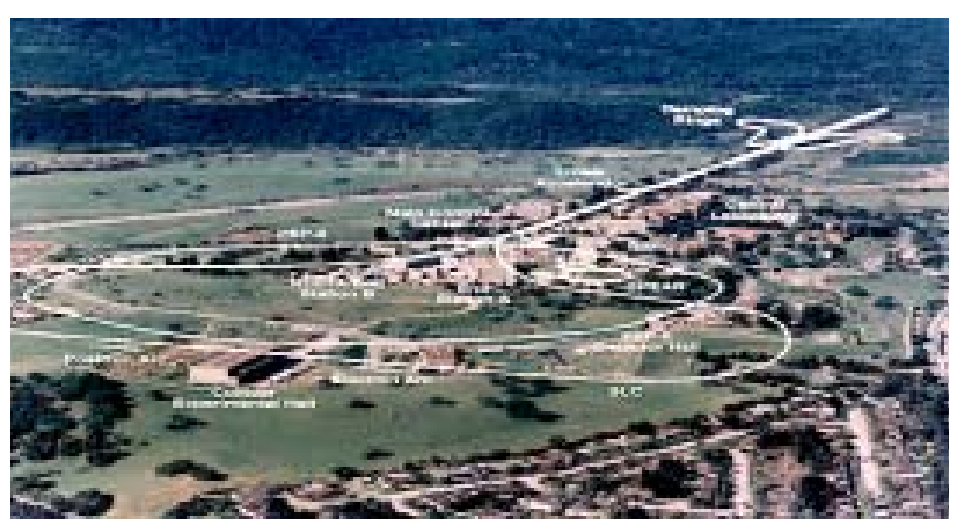

Site 0 verview

\subsection{Introduction}

The Stanford Linear Accelerator Center (SLAC) is a national facility operated by Stanford University under contract with the Department of Energy (DOE). SLAC is located on the San Francisco Peninsula, about halfway between San Francisco and San Jose, California (see Figure 1-1).

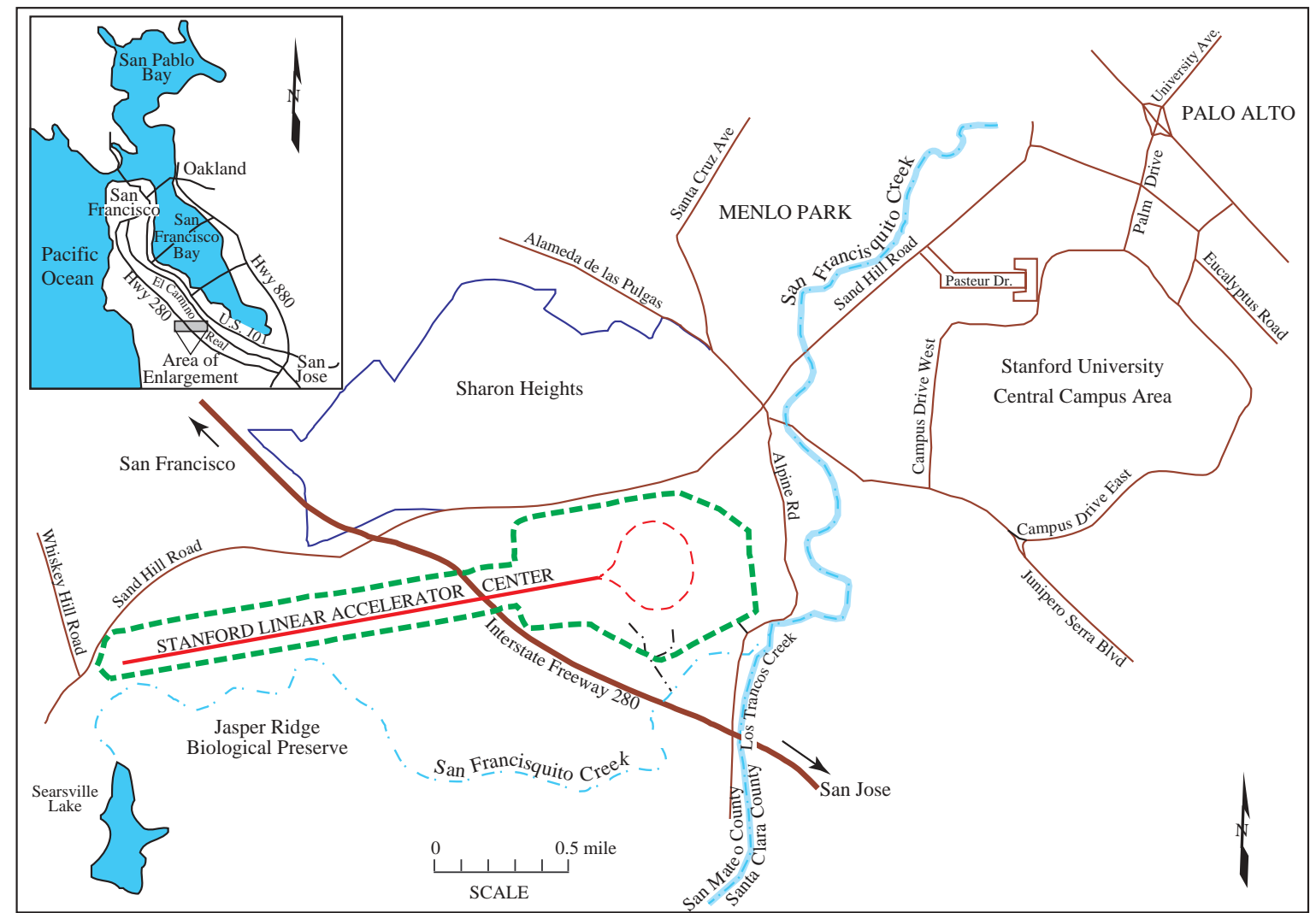

Figure 1-1 SLAC Site Location 
The site area is in a belt of low, rolling foothills lying between the alluvial plain bordering San Francisco Bay on the east and the Santa Cruz Mountains on the west. The accelerator site varies in elevation from 53 to 114 meters (m) above sea level. The alluvial plain to the east around the Bay lies less than $46 \mathrm{~m}$ above sea level; the mountains to the west rise abruptly to over $610 \mathrm{~m}$ (see Figure 1-2).

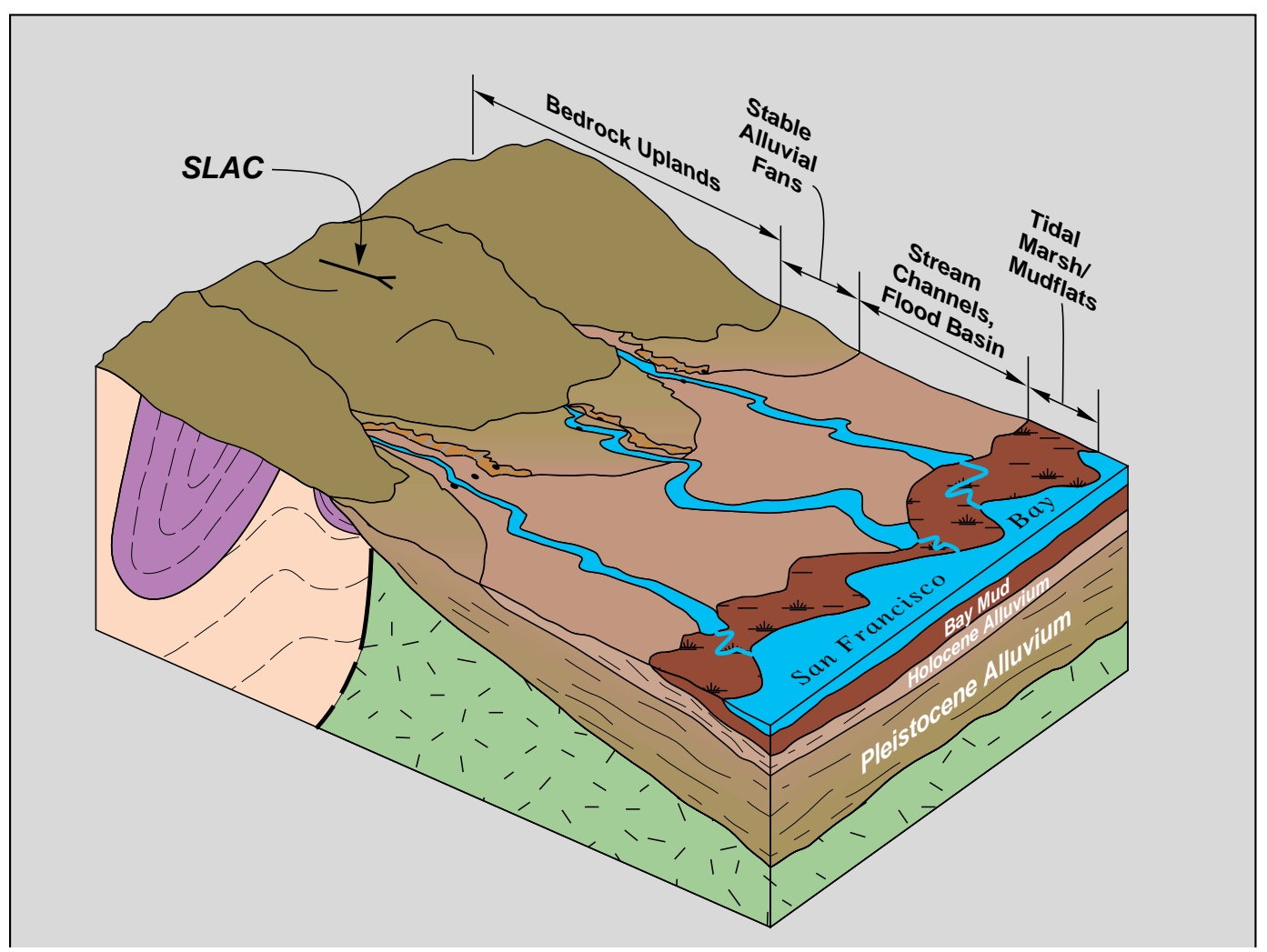

Figure 1-2 G eographic Site Area

The SLAC site occupies 170 hectares of land owned by Stanford University. The property was leased in 1962 for purposes of research in the basic properties of matter. The original lease to the Atomic Energy Commission (AEC), now DOE, was for fifty years. The land is part of Stanford's "academic reserve," and is located west of the University and the City of Palo Alto in an unincorporated portion of San Mateo County.

The site is bordered on the north by Sand Hill Road and on the south by San Francisquito Creek. The laboratory is located on an elongated parcel roughly 3.2 kilometers $(\mathrm{km})$ long, running in an east-west direction. The parcel widens to about $910 \mathrm{~m}$ at the target (east) end to allow space for buildings and experimental facilities.

The SLAC population currently numbers about 1,350 people, of which about 150 are Ph.D. physicists. Approximately 800 staff members are professional, composed of physicists, engineers, programmers, and other scientific-related personnel. The balance of the staff is composed of support personnel, including technicians, crafts personnel, laboratory assistants, and administrative associates. In addition to the regular population, at any given time SLAC hosts between 900 and 1,000 visiting scientists. 


\subsection{Site G eology}

The SLAC site is underlain by sandstone, with some basalt at the far eastern end of the site boundary. In general, the bedrock on which the western half of the SLAC linac rests is the Whiskey Hill Formation (Eocene age), and the bedrock under the eastern half is the Ladera Formation (Miocene age). On top of this bedrock at various places along the accelerator alignment is the Santa Clara Formation (Pleistocene age), where alluvial deposits of sand and gravel are found. At the surface is a soil overburden of non-consolidated earth material averaging from 0.1 to $1.5 \mathrm{~m}$ in depth.

\subsection{Local Climate}

The climate in the SLAC area is Mediterranean. Winters are cool and moist, and summers are mostly warm and dry. Long-term weather data describing conditions in the area have been assembled from official and unofficial weather records at Palo Alto Fire Station Number 3, which is $4.8 \mathrm{~km}$ east of SLAC. The SLAC site is 60 to $120 \mathrm{~m}$ higher than the Palo Alto Station and is free of the moderating influence of the city; temperatures therefore average about two degrees lower than those in Palo Alto. Daily mean temperatures are seldom below zero degrees Centigrade or above 30 degrees Centigrade.

Rainfall averages about 560 millimeters $(\mathrm{mm})$ per year. The distribution of precipitation is highly seasonal. About $75 \%$ of the precipitation, including most of the major storms, occurs during the four-month period from December through March. Most winter storm periods are from two days to a week in duration. The storm centers are usually characterized by relatively heavy rainfall and high winds. The combination of topography and air movement produces substantial fluctuations in intensity, which can best be characterized as a series of storm cells following one another so as to produce heavy precipitation for periods of five to fifteen minutes with lulls in between.

\section{$1.4 \quad$ Land U se}

San Mateo County has the ultimate planning responsibility for University lands that are within the county, but not within an incorporated city. The San Mateo County General Plan applies to such lands.

The Board of Trustees of Stanford University is responsible for protecting Stanford's land endowment for present and future generations of students and faculty. Board policies are designed to encourage land uses consistent with the institutional purposes of Stanford, and to discourage those uses that do not further the goals of the University. However, the University also recognizes the importance of cooperation with adjoining communities and the concerns of neighboring jurisdictions are considered in the planning process.

\subsection{Program Description}

The SLAC program centers around experimental and theoretical research in elementary particle physics using accelerated electron beams and a broad program of research in atomic and solid-state physics, chemistry, and biology using synchrotron radiation from accelerated electron beams. There is also an active program in the development of accelerators, detectors, and new sources and instrumentation for synchrotron radiation research. Scientists from all parts of the United States and from throughout the world participate in the experimental programs at SLAC.

The main instrument of research is the 3.2-km linear accelerator (linac), which generates highintensity beams of electrons and positrons up to $50 \mathrm{GeV}$. The linac is also used for injecting electrons and positrons into colliding-beam storage rings for particle physics research.

The Positron-Electron Project (PEP) storage ring is about 800 meters in diameter. While the original PEP program was completed in 1990, the storage ring has since been upgraded to serve as an 
Asymmetric $B$ Factory (known as PEP-II) to study the $B$ meson. PEP-II continued its program with the BaBar detector throughout 2001.

A smaller storage ring, the Stanford Positron-Electron Asymmetric Ring (SPEAR), contains a separate, shorter linac and a booster ring for injecting accelerated beams of electrons. SPEAR is fully dedicated to synchrotron radiation research. The synchrotron light generated by the SPEAR storage ring is used by the Stanford Synchrotron Radiation Laboratory (SSRL) to perform experiments. SLAC is also host of the Next Linear Collider (NLC) test facilities, including the Final Focus Test Beam (FFTB) and the Next Linear Collider Test Accelerator (NLCTA).

\subsection{Site Water U sage}

SLAC domestic water is furnished via the Menlo Park Municipal Water Department (MPMWD), whose source is the City of San Francisco-operated Hetch Hetchy aqueduct system from reservoirs in the Sierra Nevada. SLAC and the neighboring Sharon Heights development, including the shopping center, receive water service from an independent system (called Zone 3) within the MPMWD. This separate system taps the Hetch Hetchy aqueduct and pumps water up to a 7,600cubic meter reservoir west of Menlo Park/Sharon Heights and north of Sand Hill Road.

The Zone 3 system was constructed in 1962 under special agreements between the City of Menlo Park, the developer of Sharon Heights, Stanford University, and the DOE. Since the cost of construction, including reservoir, pump station, and transmission lines, was shared among the various parties, each party has a vested interest and is entitled to certain capacity rights in accordance with these agreements.

Drinking water and process water are transported throughout the facility by a distribution system protected by backflow prevention devices. The backflow prevention devices are maintained by the Site Engineering and Maintenance (SEM) Department. SLAC has no drinking-water wells. The drinking-water well nearest to SLAC is 1,500 feet from the SLAC boundary.

Use of water at SLAC is about equally divided between water used to cool equipment (such as the linac) and domestic uses (such as landscape irrigation and drinking water). The average water consumption by SLAC was 265,313 gallons per day or 96,839,245 gallons total for 2001 .

Since cooling the linac accounts for more than half of the total water consumption, the daily consumption of this component of water usage varies directly with the accelerator running schedule, and hence also varies directly with electric power demand. In contrast, the domestic water usage is relatively constant and is independent of the accelerator schedule.

The relationship between power and water consumption can be appreciated if one considers that $85 \%$ of the power used in linac operation is finally dissipated by water evaporation, in the ratio of about 630 kilowatt-hours $(\mathrm{kWh})$ per cubic meter of water. SLAC now employs six cooling-water towers with a total cooling capacity of 79 megawatts (MW) to dissipate the heat generated by the linac and other experimental apparati.

Power-consuming devices are cooled by a recycling closed-loop system of low-conductivity water (LCW). The LCW is piped from the accelerator (or other devices to be cooled) to the cooling towers, where heat is transferred from the closed system to the domestic water in the towers. Prior to discharge, the LCW from the closed system is periodically sampled and analyzed.

A sizeable portion of the domestic water in each cooling tower reservoir is ultimately evaporated into the atmosphere. Because of this continual evaporation during operation, the remaining water gradually increases in mineral content, and eventually some must be discharged as "blowdown" water and replaced with domestic water. SLAC discharged a total of 15,981,411 gallons of wastewater to the sanitary sewer system in 2001, an average of 43,785 gallons per day. 


\subsection{Demographics}

The populated area around SLAC is a mix of offices, schools, single-family housing, apartments, condominiums, Stanford University, and grazing lands. SLAC is surrounded mainly by five communities: Atherton town, West Menlo Park, Portola Valley town, Woodside town, and Stanford. Table 1-1 shows data on the population, housing, and area of these five communities (data from 1990 census).

Table 1-1 Demographic Data

\begin{tabular}{|l|c|c|c|c|}
\hline G eographic Area & $\begin{array}{c}\text { Population } \\
\text { (persons) }\end{array}$ & $\begin{array}{c}\text { Pop. Density } \\
\text { (per sq mile) }\end{array}$ & $\begin{array}{c}\text { Housing } \\
\text { (units) }\end{array}$ & $\begin{array}{c}\text { Land Area } \\
\text { (sq mile) }\end{array}$ \\
\hline \hline Atherton town & 7,163 & $1,463.32$ & 2,518 & 4.895 \\
\hline West Menlo Park & 3,959 & $7,086.19$ & 1,701 & 0.559 \\
\hline Portola Valley town & 4,194 & 458.02 & 1,675 & 9.157 \\
\hline Woodside town & 5,035 & 428.88 & 1,892 & 11.740 \\
\hline Stanford & 18,097 & $6,569.14$ & 4,770 & 2.755 \\
\hline Total & 38,448 & NA & 12,556 & 29.105 \\
\hline
\end{tabular}

Assessments made for compliance with the Clean Air Act require SLAC to estimate population located within $80 \mathrm{~km}$ of the site. Based on 1990 census data, 4,917,443 people live within $80 \mathrm{~km}$ of SLAC. The approximate distribution of this population is shown in Table 12 in Appendix B. (In Table 12 of Appendix B, the land area within $80 \mathrm{~km}$ of SLAC is divided into 13 concentric rings, with SLAC at the center. Each ring is further divided into 16 wedges of 22.5 degrees each, oriented to compass directions.) 


\section{Environmental Compliance}

\subsection{Introduction}

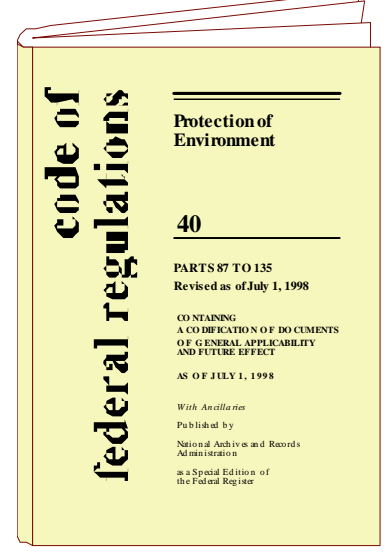

This chapter provides an overview of the Environment, Safety, and Health (ES\&H) Division's Environmental Management System, responsibilities, organization, and quality programs. This chapter also includes summary tables of the permits that are in place, events that occurred, and compliance status during 2001.

The ES\&H program is designed to ensure that Stanford Linear Accelerator Center (SLAC) operates in a safe, environmentally responsible manner and complies with applicable environment, safety, and health laws, regulations, and standards.

\subsection{Environmental Management System}

Stanford University provides the land for the SLAC site to the DOE at no cost, charging no rent and exacting no fee. The University manages the land with an eye to the future and to the future generations, thus ensuring proper stewardship and the eventual return of the land to unrestricted use. The SLAC Safety Management System (SLAC ISMS Plan) includes Environmental Management Systems accordingly.

Environmental management meets the goals of ISMS originally designed by the DOE. The SLAC commitment to integrating environment, safety, and health considerations into its mission preceded the establishment of the DOE ISMS requirements. This was evident in the strong ES\&H Program developed by SLAC long before the ISMS clause was incorporated into the operating contract. The traditional approach to "plan, do, check, and improve" that is seen in environmental management systems is reflected in the following five core functions (CF) of ISMS:

-Core Function 1(Define the Scope of Work)

-Core Function 2 (Analyze the Hazards)

-Core Function 3 (Develop and Implement Hazard Controls)

- Core Function 4 (Perform Work Within Controls)

-Core Function 5 (Provide Feedback and Continuous Improvement)

The core functions are supported by the following seven guiding principles (GP) of ISMS:

-Guiding Principal 1 (Line Management Responsibility for Safety)

-Guiding Principal 2 (Roles and Responsibilities)

-Guiding Principal 3 (Competence Commensurate with Responsibilities)

-Guiding Principal 4 (Balanced Priorities)

- Guiding Principal 5 (Identification of Safety Standards)

- Guiding Principal 6 (Hazard Controls Tailored to Work Being Performed)

-Guiding Principal 7 (Operations Authorization)

Specific examples of SLAC programs related to these functions and principals are shown in the following subsections. 


\subsubsection{Roles and Responsibilities}

The EMS at SLAC has the same roles and responsibilities as those identified in the ISMS (GP1 Line Management Responsibility for Safety, and GP2 Roles and Responsibilities).

- The Director has ultimate responsibility for the laboratory's ES\&H Program and for delegating the responsibility and authority necessary to implement ES\&H policies.

- The Associate Directors manage divisions of the laboratory and are responsible for ensuring that ES\&H policy is implemented within their own divisions.

- Managers and supervisors direct operations and functions of a division, a scientific or a support department, or a research group or program. They are responsible for implementing ES\&H policies with the personnel under their supervision.

\subsubsection{Work Smart Standards Summary}

The laws and regulations that specify the environmental, safety, and health requirements for the laboratory have been identified and are contained in the SLAC Work Smart Standards (WSS) Set. This set of standards was incorporated into the SLAC Management and Operating contract and is reviewed annually to ensure the goals of GP5 (Identification of Safety Standards) are met.

The WSS Set requirements are based on and respond to potential hazards that have been identified by the people who work at SLAC.

\subsubsection{Safety Management System Summary}

The SLAC Safety Management System (SLAC-I-720-0A008-001) document describes the SLAC safety management system program and how SLAC integrates safety and environmental protection into management and work practices at all levels so that the SLAC mission is accomplished while protecting the worker, the public, and the environment. The components of the SLAC safety management system program, including the description document, may be viewed at:

http://www.slac.stanford.edu/esh/isms/slacisms.html

\subsection{Organizational Overview}

The 2001 ES\&H Division consists of five departments, a division office, and a Program Planning

Office. Their shared goal is to help ensure that SLAC operates in compliance with federal, state, and local regulations, as well as Department of Energy (DOE) Orders related to environment, safety, and health. The five departments are:

\subsubsection{Environmental Protection and Restoration (EPR)}

The EPR Department oversees the majority of the SLAC environmental programs, including environmental restoration, air quality, storm water and industrial wastewater toxic substance control, and groundwater protection.

\subsubsection{Operational Health Physics (OHP)}

The OHP Department oversees radiological monitoring, dosimetry, and radioactive waste management at SLAC.

\subsubsection{Radiation Physics (RP)}

The RP Department provides expertise in shielding design for new experiments and facilities and provides oversight for the safe operation of beamlines so that workers and members of the general public are protected. 


\subsubsection{Safety, Health, and Assurance (SHA)}

The SHA Department manages the overall safety, health, and QA programs and oversees audits for quality assurance (QA) for ES\&H activities.

\subsubsection{Waste Management (WM)}

The WM Department develops and implements waste minimization and pollution prevention plans and coordinates the disposal of regulated waste.

\subsection{Environmental Permits and Notifications}

The general types of permits held by SLAC in 2001 are shown in Table 2-1. The specific permits held by SLAC in 2001 are shown in Table 2-2.

Table 2-1 General Permits and Notifications

\begin{tabular}{|c|c|}
\hline Quantity & Name \\
\hline 25 & $\begin{array}{l}\text { Sources listed on the Bay Area Air Quality Management District (BAAQMD) Permit-to-Operate } \\
\text { (18 Permitted Sources, } 7 \text { Exempt Sources). For more information, see Table 3-1. }\end{array}$ \\
\hline 4 & $\begin{array}{l}\text { Notifications to US EPA for halogenated solvent cleaning units are under the National Emission } \\
\text { Standards for Hazardous Air Pollutants (NESHAP Program). }\end{array}$ \\
\hline 3 & $\begin{array}{l}\text { Mandatory Wastewater Discharge Permits issued jointly by the South Bayside System Authority } \\
\text { (SBSA) and the West Bay Sanitary District (WBSD). }\end{array}$ \\
\hline 2 & Tiered Permits for Fixed Treatment Units (Permit-By-Rule [PBR] Permit) \\
\hline 2 & Tiered Permit for Fixed Treatment Units (Conditional Authorization Permit) \\
\hline 1 & Industrial Activities Storm Water General Permit \\
\hline 1 & Hazardous Waste Generator Environmental Protection Agency (EPA) ID No. CA8890016126 \\
\hline 1 & $\begin{array}{l}\text { Synthetic Minor Operating Permit (pending), issued by BAAQMD per the local implementation } \\
\text { of Tittle V of the Clean Air Act }\end{array}$ \\
\hline
\end{tabular}


Table 2-2 Specific Permits

\begin{tabular}{|c|c|c|c|}
\hline Permit From & Permit Type & Permit Number & $\begin{array}{l}\text { Expiration } \\
\text { Date }\end{array}$ \\
\hline BAAQMD & Permit-to-Operate & Plant No. 556, 25 listed sources & July 1,2001 \\
\hline \multirow[t]{4}{*}{$\begin{array}{l}\text { Department of Toxic } \\
\text { Substances Control (DTSC) }\end{array}$} & \multirow[t]{4}{*}{$\begin{array}{l}\text { Tiered Permit for fixed } \\
\text { treatment units }\end{array}$} & $\begin{array}{l}\text { Unit 1-Building 038, PBR } \\
\text { Permit for Rinse Water Treat- } \\
\text { ment Plant (RWTP) }\end{array}$ & March 30, 2002 \\
\hline & & $\begin{array}{l}\text { Unit 2-Building 038, Sludge } \\
\text { Dryer (PBR) }\end{array}$ & March 30, 2002 \\
\hline & & $\begin{array}{l}\text { Unit } 3 \text {-Building } 460 \text {, } \\
\text { Conditional Authorization Per- } \\
\text { mit for Batch Treatment Plant } \\
(\mathrm{BTP})^{\mathrm{a}}\end{array}$ & March 30, 2002 \\
\hline & & $\begin{array}{l}\text { Unit 4-FSUST, Conditional } \\
\text { Authorization Permit for } \\
\text { Groundwater Treatment System }\end{array}$ & March 30, 2002 \\
\hline \multirow[t]{3}{*}{ WBSD and SBSA } & \multirow[t]{3}{*}{ Wastewater Discharge } & $\begin{array}{l}\text { Permit No. WB970401-F } \\
\text { (Flow Meter Station at Sand } \\
\text { Hill Road) }\end{array}$ & March 31, 2002 \\
\hline & & $\begin{array}{l}\text { Permit No. WB970401-P } \\
\text { RWTP }\end{array}$ & March 31, 2002 \\
\hline & & $\begin{array}{l}\text { Permit No. WB970401-HX } \\
\text { BTP }\end{array}$ & March 31, 2002 \\
\hline $\begin{array}{l}\text { San Francisco Bay Regional } \\
\text { Water Quality Control Board } \\
\text { (RWQCB) }\end{array}$ & $\begin{array}{l}\text { Industrial Activities } \\
\text { Storm Water General } \\
\text { Permit }\end{array}$ & Permit No. CAS000001 & July 1,2002 \\
\hline
\end{tabular}

a In the Tiered Permits, this plant is referred to as a facility.

\subsection{Assessments, Inspections, and Quality Assurance}

The following two types of regular radiological environmental protection (REP) program evaluations were conducted between SLAC and off-site regulators during 2001:

- Quarterly operational awareness reviews of the SLAC REP by DOE subject matter experts from the Oakland, CA office.

- Quarterly monitoring of SLAC perimeter radiation by the California Department of Health Services.

In the above evaluations, no radiological or regulatory problems were found.

\subsubsection{Self-Assessment Program}

An annual Talk, Walk, Clean (TWC) program is used at SLAC to identify opportunities for ES\&H improvement. This program includes the opportunity for all laboratory employees, in small discussion groups, to reflect on the most important ES\&H issues and suggest solutions. Divisions may take action on this information directly, or they may develop sitewide corrective action plans. A structured walk-through inspection and a clean-up opportunity were also provided. As of October 7, 2002, 18 of 37 (49\%) of the 2001 "Talk" program findings have been completed. 


\subsubsection{Inspections}

South Bayside System Authority conducted its routine annual inspection of SLAC facilities per the three current wastewater discharge permits. No corrective actions were noted.

\subsubsection{Quality Assurance}

The SLAC site-wide Quality Assurance (QA) Program has been influenced by the requirements of DOE Order 414.1. The QA Program is described in the SLAC Institutional Quality Assurance Program Plan (SLAC-I-770-0A17M-001). This document was revised in September of 2000. The plan defines the roles, responsibilities, and authorities for implementation of the ten criteria from DOE Order 414.1.

The SHA Department is responsible for:

- Auditing quality assurance for line work as well as environment, safety, and health (ES\&H) programs.

- Maintaining the SLAC Institutional Quality Assurance Program Plan.

- Providing direction for implementation of the ten criteria from DOE Order 414.1.

\subsubsection{Independent Assessment Program}

A major multi-year program of assessments related to environment, safety, and health topics is in place at SLAC. This assessment is conducted each year by a consulting firm (for 2001, URS Corporation) during two visits per year. The assessment personnel are highly qualified ES\&H professionals.

In 2001, the first independent assessment by URS was held April 9 - 13. This assessment addressed:

- Radioactive/Hazardous Waste Programs/Waste Accumulation Areas

- Radioactive Material (Packaging and Transportation)

- Radiation Protection per DOE requirements

- Radiation Dosimetry Sweep (DOE/LAP)

- Hazardous Materials (Storage, packaging, and transportation)

- Medical Waste Program

- Air Program Review

As of October 7, 2002, 71 of 72 findings have been corrected.

The second independent assessment of 2001 was held November 12 - 16, 2001. This assessment addressed:

- General Health and Safety

- Electrical Safety

- Emergency Response

- Groundwater/Soils programs

During this assessment, eighty-one findings were reported, all at hazard level three (note that URS Corporation uses a range of four levels with level one as the most serious and level four as the least serious). As of October 7 , 2002,56 of $81(69 \%)$ of these findings had been corrected.

\subsubsection{Radioanalysis Laboratory}

SLAC participates in the DOE Quality Assessment Program. Under this program, the DOE Environmental Measurements Laboratory (EML) provides the SLAC radioanalysis lab with samples that contain unknown gamma- and beta-emitting radionuclides. SLAC uses these samples to test and improve 
its gamma counting and liquid scintillation counting capabilities. In 2001, the SLAC radioanalysis lab correctly identified all radionuclides present in the EML samples.

\subsubsection{Environmental Monitoring}

Table 2-3 lists the procedures and policies used to support the QA Program for environmental monitoring activities.

Table 2-3 QA Program Documents

\begin{tabular}{|l|l|}
\hline Document \# & Title \\
\hline \hline QC-030-004-00-R0 & Radioactive Water Sampling/Analysis Audit Procedure \\
\hline SLAC-I-770-0A19C-001 & Oversight Procedure \\
\hline SLAC-I-770-2A19C-004 & Non-Radiological Sampling Audit Procedure \\
\hline SLAC-I-770-0A16Z-001 & Establishing Data Quality Objectives \\
\hline
\end{tabular}

\subsubsection{Environmental Restoration Program}

The Environmental Restoration Program uses the Quality Assurance Project Plan for the Remedial Investigation and Feasibility Study (SLAC-I-7502A17M-003) for soil and groundwater contamination investigations. This document has most components required of Quality Assurance Project Plans according to the EPA; the Comprehensive Environmental Response, Compensation, and Liability Act (CERCLA, or Superfund); and DOE guidance documents. The components include defining required laboratory and field $\mathrm{QA} / \mathrm{QC}$ procedures and corrective actions, and data validation and reporting.

\subsection{Environmental Incidents}

Table 2-4 summarizes incidents which exceeded regulatory permit limits or local, state, or federal reporting requirements.

Note: The releases shown in Table 2-4 were unauthorized non-storm water discharges under the General Industrial Stormwater Permit.

Table 2-4 Environmental Incidents Summary

\begin{tabular}{|l|l|l|l|l|l|}
\hline Date & Material $^{\mathbf{a}}$ & Amount & Location & Description & $\begin{array}{l}\text { Corrective Action } \\
\text { Taken }\end{array}$ \\
\hline \hline $3-5-01$ & $\begin{array}{l}\text { Domestic } \\
\text { and cool- } \\
\text { ing tower } \\
\text { water }\end{array}$ & 80,000 gallons & $\begin{array}{l}\text { End } \\
\text { Station A }\end{array}$ & $\begin{array}{l}\text { The cooling system water } \\
\text { line ruptured }\end{array}$ & The pipe was repaired \\
\hline $4-10-01$ & $\begin{array}{l}\text { Cooling } \\
\text { tower } \\
\text { water }\end{array}$ & 13,400 gallons & $\begin{array}{l}\text { End } \\
\text { Station A }\end{array}$ & $\begin{array}{l}\text { The cooling system water } \\
\text { line ruptured }\end{array}$ & The pipe was repaired \\
\hline $12-28-01$ & $\begin{array}{l}\text { Cooling } \\
\text { tower } \\
\text { water }\end{array}$ & 50,000 gallons & $\begin{array}{l}\text { Cooling } \\
\text { Tower } \\
1202\end{array}$ & $\begin{array}{l}\text { A cooling system circu- } \\
\text { lating line ruptured }\end{array}$ & The pipe was repaired \\
\hline
\end{tabular}

a Domestic water is the source of cooling tower water. 


\subsubsection{Non-Radiological Incidents}

As summarized above in Table 2-4, three releases resulted in notification to the Regional Water Quality Control Board and the San Mateo County Health Department.

On March 5, 2001, a cooling system water pipe broke at End Station A, releasing water to the storm drain system. The back-up cooling system, using domestic water, overloaded the sanitary sewer lift station, eventually releasing water into the storm drain. Approximately 10,000 gallons of cooling tower water and 70,000 gallons of domestic water entered the storm drain system. An estimated $10 \%$ of the domestic water release was sewage. The pipe break was located and repaired. Note that domestic (drinking) water is the source of cooling tower water. The pipe was repaired promptly.

On April 10, 2001, a cooling system water pipe broke near End Station A, releasing water into the storm drain system. The back-up cooling system, using domestic water, overloaded the sanitary sewer lift station, again releasing water into the storm drain. Approximately 5,000 gallons of cooling tower water and 8,400 gallons of domestic water entered the storm drain system. An estimated $10 \%$ of the domestic water release was sewage. The cooling tower was immediately shut down and the pipe repaired.

On December 28, 2001, a circulating pipe ruptured at Cooling Tower 1202, releasing water into the storm drain. About 50,000 gallons of cooling tower water entered the storm drain system. The cooling tower was immediately shut down and the pipe repaired.

SLAC submitted a line-item request to DOE, under the Science Laboratory Infrastructure (SLI) program, the Safety and Operational Reliability Improvements Project in FY04 to upgrade the underground utility systems and perform seismic retrofit of mission-critical facilities. This $\$ 15.6$ million project will provide approximately $\$ 7$ million in funding to upgrade the piping systems.

\subsubsection{Radiological Incidents}

In 2001, no radiological incidents occurred that increased radiation levels or released radioactivity to the environment. As detailed in Chapter 4, our information shows that SLAC was in compliance with all radiological requirements related to the environment throughout 2001.

\subsection{Training}

In 2001, for personnel who handled hazardous chemicals and waste, instruction was offered in chemical and waste management, waste minimization, pollution prevention, storm water protection, on-site transportation of hazardous chemicals and waste, and spill and emergency response. The classroom instruction provided was intended to increase awareness in the aforementioned areas and to ensure environmental compliance.

\subsection{Environmental Performance Measures}

SLAC evaluates its performance against performance measures. The measures included:

- Environmental Violations and Releases

- Environmental Restoration Goals

- Waste Minimization/Pollution Prevention Goals

- Hazardous and Radioactive Waste

\subsubsection{Specific Measures}

The specific performance measures for FY01 can be found at:

http://www.slac.stanford.edu/esh/isms/perfmeas.html 


\subsubsection{Results}

Performance measure results are reported in a fiscal year structure; the SLAC fiscal year 2001 (FY01) covered October 1, 2001 through September 30, 2001. The performance measure results for FY01, as found in the Stanford Linear Accelerator Center Environment, Safety, and Health Fourth Quarter Report (October 1-December 31, 2001) indicated an "Outstanding" on violations and releases, as shown in Table 2-5.

Table 2-5 FY01 Performance Measure Results

\begin{tabular}{|l|c|}
\hline \multicolumn{1}{|c|}{ Performance Measure } & Results $^{\mathbf{a}}$ \\
\hline \hline Environmental Violations and Releases & Excellent \\
\hline Environmental Restoration Goals & Outstanding \\
\hline Radiation Dose/Emissions & Excellent \\
\hline Hazardous Waste & Outstanding \\
\hline Radioactive Waste & Outstanding \\
\hline Waste Minimization/Pollution Prevention Goals & Outstanding \\
\hline
\end{tabular}

a Effective in 2001, DOE changed the language used to summarize performance measure results. The range of possible performance measure results (from best to worst) is now Outstanding, Excellent, Good, Marginal, Unsatisfactory.

\subsection{Program Compliance Summary}

Table 2-6 lists the major statutes, executive orders, and other documents that govern activities at SLAC. It also indicates the location of the data in this document, along with any pertinent comments. 
Table 2-6 Compliance Summary (page 1 of 3)

\begin{tabular}{|c|c|c|c|c|}
\hline $\begin{array}{l}\text { Major Statute/Executive } \\
\text { Order }\end{array}$ & Governing Document & Status* & ASER Location & $\begin{array}{l}\text { Pertinent Documents, } \\
\text { Programs, Activities, and } \\
\text { Accomplishments in } 2001\end{array}$ \\
\hline $\begin{array}{l}\text { Superfund Amendments and Reautho- } \\
\text { rization Act } \\
\text { (SARA)/ EPCRA } \\
42 \text { USC, Section } 11022 \text { (Tier II) }\end{array}$ & $\begin{array}{l}\text { San Mateo County } \\
\text { Ordinance } \\
\text { California Health and Safety } \\
\text { (CHS), Chapter 6.95; Article } \\
\text { 80, Uniform Fire Code }\end{array}$ & $\begin{array}{l}\text { Meets } \\
\text { Requirements }\end{array}$ & Section 3.7 & $\begin{array}{l}\text { The Hazardous Materials Business } \\
\text { Plan and Hazardous Material } \\
\text { Annual Inventory }\end{array}$ \\
\hline $\begin{array}{l}\text { Resource Conservation and Recovery } \\
\text { Act (RCRA) 40CFR261 }\end{array}$ & $\begin{array}{l}\text { Title } 22 \text { California Code of } \\
\text { Regulations }\end{array}$ & $\begin{array}{l}\text { Meets } \\
\text { Requirements }\end{array}$ & Section 3.6.1 & $\begin{array}{l}\text { Hazardous Waste Generator } \\
\text { requirements }\end{array}$ \\
\hline $\begin{array}{l}\text { National Environmental Policy Act } \\
\text { (NEPA) }\end{array}$ & $\begin{array}{l}\text { NEPA- } 42 \text { USC } 4321-4347,(40 \\
\text { CFR parts } 1500-1508)\end{array}$ & $\begin{array}{l}\text { Meets } \\
\text { Requirements }\end{array}$ & Section 3.9.1 & $\begin{array}{l}\text { Initial scope activities for LCLS } \\
\text { (EA) }\end{array}$ \\
\hline Clean Air Act & $\begin{array}{l}\text { 40CFR63 and 40CFR82 } \\
\text { BAAQMD } \\
\text { Rules and Regulations }\end{array}$ & $\begin{array}{l}\text { Meets } \\
\text { Requirements }\end{array}$ & Section 3.3 and 4.1 & $\begin{array}{l}\text { SLAC has both a radiological and } \\
\text { non-radiological air quality protec- } \\
\text { tion programs }\end{array}$ \\
\hline Clean Water Act- Groundwater & $\begin{array}{l}\text { Federal Water Pollution Con- } \\
\text { trol Act (Clean Water Act) - } 33 \\
\text { USC } 1344 \\
\text { (40 CFR Section } 400 \text { et seq.) }\end{array}$ & $\begin{array}{l}\text { Meets } \\
\text { Requirements }\end{array}$ & $\begin{array}{l}\text { Section } 3.4 .1 \text { and } \\
\text { Chapter } 5\end{array}$ & $\begin{array}{l}\text { New wells were installed in } 2000 \text { to } \\
\text { evaluate specific locations for cer- } \\
\text { tain potential constituents near } \\
\text { SLAC facilities }\end{array}$ \\
\hline Clean Water Act- Surface Water & $\begin{array}{l}\text { Stormwater Pollution } \\
\text { Prevention Plan (SWPPP) }\end{array}$ & $\begin{array}{l}\text { Meets } \\
\text { Requirements }\end{array}$ & Section 3.4 .2 & $\begin{array}{l}\text { SLAC expanded its Stormwater } \\
\text { Monitoring Program to ensure con- } \\
\text { tinued compliance with the require- } \\
\text { ments of the General Permit }\end{array}$ \\
\hline $\begin{array}{l}\text { Clean Water Act- } \\
\text { Industrial Wastewater }\end{array}$ & $\begin{array}{l}\text { Regulations of South Bayside } \\
\text { System Authority; Code of } \\
\text { General Regulations of the } \\
\text { West Bay Sanitary District } \\
\text { Three Mandatory Wastewater } \\
\text { Discharge Permits }\end{array}$ & $\begin{array}{l}\text { Meets } \\
\text { Requirements }\end{array}$ & Section 3.4 .3 & $\begin{array}{l}\text { SLAC remained in compliance } \\
\text { with requirements of its } 3 \text { wastewa- } \\
\text { ter discharge permits; annual } \\
\text { inspection by SBSA was routine } \\
\text { and generated no enforcement } \\
\text { actions or violations }\end{array}$ \\
\hline
\end{tabular}

* "Meets Requirements" means that SLAC has implemented systems and programs designed to ensure compliance with applicable requirements. 
Table 2-6 Compliance Summary (page 2 of 3)

\begin{tabular}{|c|c|c|c|c|}
\hline $\begin{array}{l}\text { Major Statute/Executive } \\
\text { Order }\end{array}$ & Governing Document & Status* & ASER Location & $\begin{array}{l}\text { Pertinent Documents, } \\
\text { Programs, Activities, and } \\
\text { Accomplishments in } 2001\end{array}$ \\
\hline $\begin{array}{l}\text { Executive Order (EO) } 13148 \text {, Green- } \\
\text { ing the Government through Leader- } \\
\text { ship in Environmental Management }\end{array}$ & Executive Order 13148 & $\begin{array}{l}\text { Meets } \\
\text { Requirements }\end{array}$ & Section 3.3.6 & $\begin{array}{l}\text { SLAC was in compliance with } \\
\text { those portions of the EO for which } \\
\text { DOE has issued Guidance }\end{array}$ \\
\hline Toxics Release Inventory & 40 CFR 372 & $\begin{array}{l}\text { Meets } \\
\text { Requirements }\end{array}$ & Section 3.3.3.3 & $\begin{array}{l}\text { SLAC Filed its Required Form R } \\
\text { reports }\end{array}$ \\
\hline Toxic Substances Control Act (TSCA) & 40CFR761 & $\begin{array}{l}\text { Meets } \\
\text { Requirements }\end{array}$ & Section 3.8 & $\begin{array}{l}\text { Revision was completed of SLAC } \\
\text { Spill Prevention, Control, and } \\
\text { Countermeasures Plan }\end{array}$ \\
\hline $\begin{array}{l}\text { Federal Insecticide, Fungicide, and } \\
\text { Rodenticide Act (FIFRA) }\end{array}$ & $\begin{array}{l}7 \text { USC Section 136, and } \\
\text { following sections }\end{array}$ & $\begin{array}{l}\text { Meets } \\
\text { Requirements }\end{array}$ & Section 3.4 .5 & $\begin{array}{l}\text { SEM personnel have been trained } \\
\text { and are performing the on-site pes- } \\
\text { ticide application. The contract } \\
\text { with licensed sub-contractors will } \\
\text { be maintained for occasional use }\end{array}$ \\
\hline $\begin{array}{l}\text { Endangered Species Act (ESA) } \\
16 \text { USC, } 1531 \text { and following sections }\end{array}$ & $\begin{array}{l}\text { Pre-Construction Notice, US } \\
\text { Army Corps of Engineers }\end{array}$ & $\begin{array}{l}\text { Meets } \\
\text { Requirements }\end{array}$ & Section 3.4 .4 & $\begin{array}{l}\text { Based on its recent wildlife sur- } \\
\text { veys, the Stanford University Cen- } \\
\text { ter for Conservation Biology } \\
\text { provided copies of survey reports } \\
\text { and an updated list of threatened } \\
\text { and endangered species on Stanford } \\
\text { lands }\end{array}$ \\
\hline $\begin{array}{l}\text { National Historic Preservation Act } \\
\text { (NHPA) }\end{array}$ & NHPA 16 USC $470 f$ & $\begin{array}{l}\text { No eligible } \\
\text { NHPA sites at } \\
\text { SLAC }\end{array}$ & Not Applicable & Not Applicable \\
\hline $\begin{array}{l}\text { Executive Order } 11988, \\
\text { Floodplain Management }\end{array}$ & $\begin{array}{l}\text { Executive Order 11988- Flood- } \\
\text { plain Management ( } 10 \text { CFR } \\
\text { Part } 1022\end{array}$ & $\begin{array}{l}\text { Meets } \\
\text { Requirements }\end{array}$ & Section 3.4 .7 & $\begin{array}{l}\text { SLAC tracked discussion of man- } \\
\text { agement options for Searsville } \\
\text { Dam, which may be lowered or } \\
\text { removed. According to FEMA, a } \\
\text { one-hundred-year flood would not } \\
\text { reach the facility. }\end{array}$ \\
\hline
\end{tabular}

* "Meets Requirements" means that SLAC has implemented systems and programs designed to ensure compliance with applicable requirements. 
Table 2-6 Compliance Summary (page 3 of 3)

\begin{tabular}{|l|l|l|l|l|}
\hline $\begin{array}{l}\text { Major Statute/Executive } \\
\text { Order }\end{array}$ & Governing Document & Status & ASER Location & $\begin{array}{l}\text { Pertinent Documents, } \\
\text { Programs, Activities, and } \\
\text { Accomplishments in 2001 }\end{array}$ \\
\hline $\begin{array}{l}\text { Executive Order 11990, Protection of } \\
\text { Wetlands }\end{array}$ & $\begin{array}{l}\text { Executive Order 11990- } \\
\text { Protection of Wetlands }\end{array}$ & $\begin{array}{l}\text { Meets } \\
\text { Requirements }\end{array}$ & Section 3.4.6 & $\begin{array}{l}\text { Jurisdictional wetlands represent } \\
\text { less than one acre of the 426-acre } \\
\text { SLAC leaseholding; still, permit } \\
\text { applications are prepared assuming } \\
\text { wetlands are present at SLAC. }\end{array}$ \\
\hline $\begin{array}{l}\text { Tank Management } \\
\text { Above-ground Petroleum Storage Act }\end{array}$ & $\begin{array}{l}\text { California Health and Safety } \\
\text { (CHS) Code, Section 25270 }\end{array}$ & $\begin{array}{l}\text { Meets } \\
\text { Requirements }\end{array}$ & Section 3.8.2 & $\begin{array}{l}\text { Gasoline Dispensing Facility } \\
\text { (GDF) designed and built on-site to } \\
\text { eliminate refueling SLAC vehicles } \\
\text { and equipment directly from tanker } \\
\text { trucks; next biennial report and fees } \\
\text { to State are due on 7/1/2002 }\end{array}$ \\
\hline
\end{tabular}

* "Meets Requirements" means that SLAC has implemented systems and programs designed to ensure compliance with applicable requirements. 


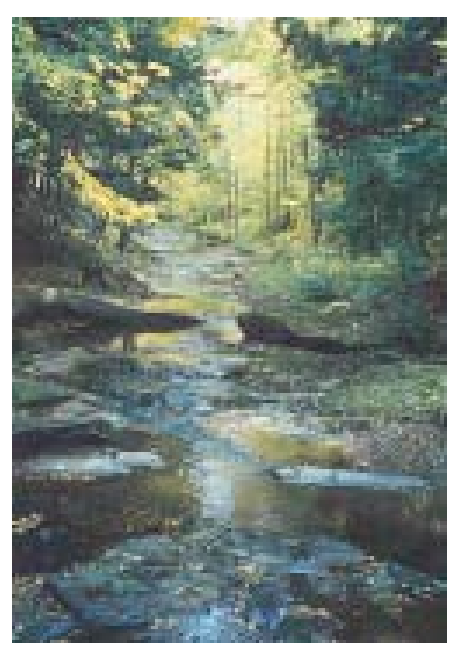

\section{Environmental Non-Radiological Program}

\subsection{Introduction}

This chapter provides an overview of non-radiological activities performed at SLAC in 2001. These activities were designed to comply with laws and regulations, and enhance environmental quality.

Key features of the non-radiological environmental program are presented: pollution prevention awards and certificates, air programs, water protection programs, waste minimization, waste management, hazardous material management, and environmental quality programs.

\subsection{Pollution Prevention Awards and Certificates}

During 2001, SLAC was recognized for efforts in Pollution Prevention by receiving awards and certificates of appreciation.

The SLAC Purchasing Department was given a Certificate of Appreciation in Pollution Prevention, by the DOE Oakland Office, for recycling accomplishments in "Return-on-Investment in Recycling of Cardboard, Paper, and Beverage Cans/Bottles." SLAC received this award for making the SLAC recycling program more cost effective.

Through competitive bidding and meetings with the existing recycling subcontractors, the Purchasing Department negotiated a program that provided SLAC with a rebate on recycled material.

At the January 23, 2001 meeting of the Menlo Park City Council, SLAC was presented with a 2000 Environmental Quality Award for our air emissions reduction project that focused on reducing emissions of chlorinated solvents to the atmosphere from the SLAC Plating Shop. When compared against the 10-year average emissions from 1988-1998, SLAC achieved emissions reductions of more than 5500 pounds per year (a reduction of more than 99\%), as shown in Figure 3-1. 


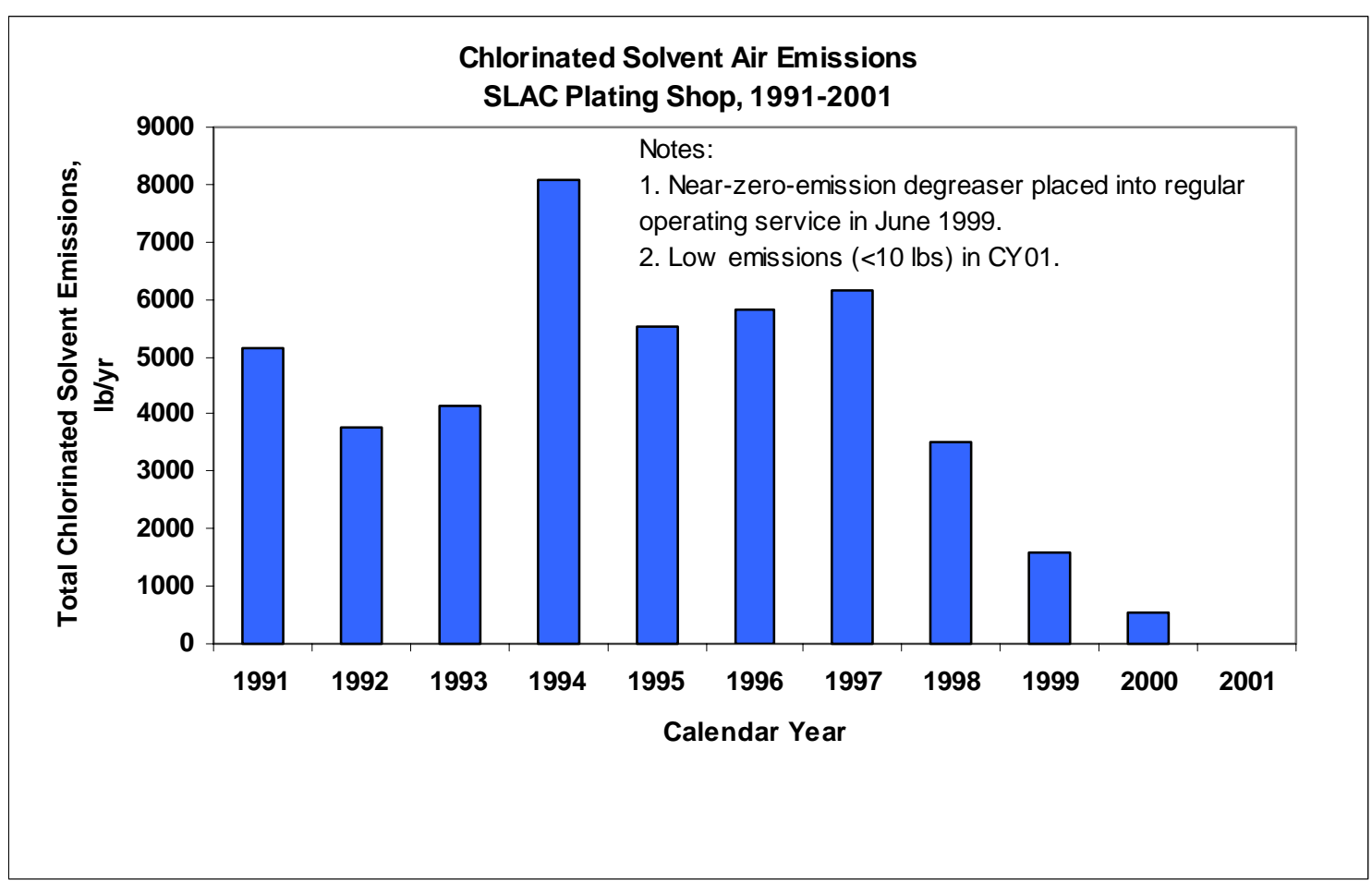

Figure 3-1 SLAC Plating Shop: Chlorinated Solvent Air Emissions

In June of 2001, the Waste Management (WM) Department received a Certificate of Achievement from the 2001 White House "Closing the Circle" award program, in the recycling category, for Implementation of Reuse Options for Potential Hazardous Wastes at SLAC.

In addition, the WM Department efforts achieved an award in the DOE Headquarters Pollution Prevention Awards Program for "...dedication and leadership in contributing to the DOE mission to prevent pollution in operations, processes and programs." Specifically, the award was for efforts in the category of Recycling-Implementing Reuse Options for Potential Hazardous Wastes.

WM worked with various organizations including other DOE facilities, electric utilities, and chemical suppliers, to send potential hazardous waste to parties that could either reuse or reclaim our waste as useful material. In turn, SLAC saved the costs associated with managing this material as hazardous waste. Over the past three years, WM reused or recycled more than sixty metric tons of potential hazardous waste and saved the lab thousands of dollars in avoided costs. Some examples of the implemented reuse activities included:

- Sending used electrical equipment that contained hazardous constituents to electrical companies that were able to service and reuse the equipment

- Developing a program to safely recycle empty chemical containers as scrap metal

- Working with SLAC departments, DOE facilities, and outside organizations to reuse laboratory chemicals that were no longer needed by the original users

In September 2001, SLAC was commended by the Santa Clara County Pollution Prevention Program "for its leadership, through participation in the Silicon Valley Chemical Management Services Pilot Project, to challenge established systems and innovate solutions that enhance both the 
economic and environmental resources of our community." (Please see Section 3.3.5 for more information about the Silicon Valley Chemical Management Services Pilot Project.)

Also in September 2001, SLAC received two awards and a certificate of appreciation from the DOE Oakland Office, for effort in pollution prevention. The certificate of appreciation recognized SLAC for "Return-on-Investment in Recycling of Cardboard, Paper, and Beverage Cans/Bottles." One award recognized work performed by a SLAC multi-department team in replacing ozonedepleting solvents with alternative solvents and cleaning methods. The other award recognized the Site Engineering and Maintenance (SEM) Department for accomplishments in Reduction/Elimination of Hazardous Waste Generation. SEM implemented waste minimization and pollution prevention at SLAC through cost savings, waste/emission reductions, innovative technologies, and innovative approaches. SEM had many accomplishments over several years, demonstrating their teamwork with ES\&H and their determination to prevent pollution.

Highlights of SEM accomplishments included the following:

- Developed an innovative approach to recycle storm water runoff from utility vaults and containment areas that cannot be roofed. In 2001, sixty-five thousand gallons of water were reused in a cooling tower, avoiding discharge to the sanitary sewer.

- Reduced polychlorinated biphenyl containing oils through equipment retrofills, replaced oilfilled electrical equipment with environmentally friendly alternative designs, and sent used equipment off-site to be reused (avoiding the disposal of thirty-five tons of reusable material).

- Recycled more than 5000 pounds of refrigerant from chillers and air conditioning equipment.

- Replaced a parts degreaser with more environmentally friendly solvent and implemented automotive battery recycling and oil filter crushing.

- Retrofitted cooling towers with covered bulk chemical storage, secondary containment, and automated feed equipment to replace chemical feed from 55-gallon drums (saving $\$ 11,000$ in waste disposal costs by eliminating the use of 55-gallon drums).

- Performed cleaning of heat exchange equipment so that cleaning solutions can be reused up to three times (reducing this operation's hazardous waste generation by $67 \%$ ).

\subsection{Air Programs}

The San Francisco Bay Area has some of the most stringent air-related regulatory requirements in the country. The scope of air quality regulations, to which SLAC is subject, has been regularly increasing since 1995. This has created a dramatic increase in the scope of the SLAC non-radiological air quality programs. SLAC has successfully addressed all of its new requirements to the satisfaction of the regulatory agencies during this time period.

\subsubsection{Regulatory Framework}

In the San Francisco Bay Area, most federal and state air regulatory programs are implemented through the rules and regulations of the Bay Area Air Quality Management District (BAAQMD). Included in the BAAQMD roles and responsibilities are implementation of Title V of the Clean Air Act (CAA). The primary mechanisms by which BAAQMD regulates SLAC air emissions include:

- New source permit evaluations.

- Annual information updates for existing permitted sources.

- Annual information updates for emissions of air toxics as identified by the California Air Resources Board in its Toxic Substances Check List.

- Asbestos and demolition project notification requirements.

- Annual information updates for adhesives usage as specified in BAAQMD 8-511502.2C. 
- Annual enforcement inspections.

SLAC is also subject to air quality regulatory programs that are administered by agencies other than the BAAQMD. These programs include the following:

- The National Emission Standards for Halogenated Solvent Cleaning, under Title 40 Code of Federal Regulations, Part 63.460 (40CFR63.460), administered through the Air Division of Region 9 of the US Environmental Protection Agency (EPA).

- The Protection of Stratospheric Ozone requirements (40CFR82) is also administered through the Air Division of EPA Region 9.

- The Toxic Chemical Release Reporting: Community Right-to-Know requirements (40CFR312). SLAC provides the appropriate information to meet these program requirements to the Department of Energy Stanford Site Office (SSO), which provides the information to DOE headquarters, which rolls-up the information from all DOE facilities and reports that information to the EPA.

- The California Accidental Release Program (CalARP), which combines the requirements of Section 112(r) of the CAA with California-specific requirements and is administered through the San Mateo County Department of Health Services (SMC/ DHS).

SLAC is waiting to hear from the San Mateo County Department of Health Services (the County) whether California Accidental Release Prevention Program (CalARP) requirements for Risk Management Plans (RMPs) will be applied to SLAC.

\subsubsection{Bay Area Air Quality Management District-Implemented Programs}

During 1999, BAAQMD revised its regulations implementing Title V of the Clean Air Act. As a result, SLAC became subject to the Title $\mathrm{V}$ permitting program and was required to take one of the following actions by October 20, 2000:

- Apply for a Major Facility Review Permit

- Demonstrate that the SLAC "potential to emit" is below the major facility thresholds defined in BAAQMD Regulation 2-6-312

- Apply for and receive a Synthetic Minor Operating Permit (SMOP).

SLAC chose to apply for a SMOP as its Title V compliance strategy. The SLAC application was submitted on June 1, 2000 and was found to be complete by BAAQMD on July 11, 2000. At the end of 2001 the SLAC SMOP application was still pending.

The major change that will be necessitated by the forthcoming SMOP will be the upgrading of the chemical information management systems at SLAC. A short-term solution of modifying the existing Peoplesoft ${ }^{\circledR}$ purchasing software was essentially complete by year-end. A new chemical management system is in the planning stages.

The forthcoming Title V SMOP permit will fundamentally change the SLAC air quality program. While permit conditions associated with the existing 18 permitted sources will be preserved under the SMOP, new facility-wide "caps" on air emissions are expected.

The focus of the SLAC permitting programs will thus be shifting from individual source recordkeeping to facility-wide recordkeeping. More information on this shift can be found in Section 3.3.5.

\subsubsection{Source Permitting}

During 2001, SLAC received permits to operate the following sources of air emissions:

- Source G-811, Gasoline Dispensing Facility (GDF) 
The GDF is a "new" source located to the west of Building 35 and the east of Building 81, in the SLAC Transportation Yard.

The GDF consists of one 2000-gallon, above-ground, double walled storage tank with a steel primary tank divided into two sections, one for 500 gallons of diesel storage and for 1500 gallons of unleaded gasoline storage.

A source test for the GDF was performed on September 26, 2001 and demonstrated the GDF was in compliance with the BAAQMD lead testing requirements. SLAC received the permit to operate the GDF in September and placed it into regular operating service in October.

Following completion of the permit process for the GDF, SLAC had a total of 25 "current" sources listed in its facility-wide Permit to Operate, including 18 permitted and 7 exempt sources. Information regarding these sources is presented in Table 3-1. 
Table 3-1 BAAQMD Permitted/Exempt Sources

\begin{tabular}{|c|c|c|c|}
\hline $\begin{array}{l}\text { Source } \\
\text { Number }\end{array}$ & Source Description & $\begin{array}{l}\text { Permitted/ } \\
\text { Exempt }\end{array}$ & $\begin{array}{l}\text { Emitted Chemicals/ } \\
\text { Materials }{ }^{1}\end{array}$ \\
\hline$\overline{S-4}$ & Batch Vapor Degreaser & Permitted & Trichloroethane (TCA) \\
\hline S-5 & Paint Spray Booth & Permitted & Paints, Solvents \\
\hline S-11 & Metal Cutting Operations & Exempt & - \\
\hline S-17 & Metal Grinding Operations & Exempt & - \\
\hline S-21 & $\begin{array}{l}\text { Anodizing, Pickling, \& Bright } \\
\text { Dip Operations }\end{array}$ & Permitted & Sulfuric Acid \\
\hline S-26 & Batch Solvent Cold Cleaner & Permitted & De-Greeze 500 \\
\hline S-34 & Batch Solvent Cold Cleaner & Permitted & De-Greeze 500 \\
\hline S-36 & Solvent Cleaning Operations & Permitted & $\begin{array}{l}\text { Ethyl Alcohol, Isopropyl Alco- } \\
\text { hol, Acetone, HCFC- } 141 \mathrm{~b} \text {, } \\
\text { Trichloroethene (TCE), TCA, oth- } \\
\text { er solvents }\end{array}$ \\
\hline S-37 & Batch Solvent Cold Cleaner & Permitted & Isopropyl Alcohol (IPA) \\
\hline S-42 & Diesel Fuel Storage Tank & Exempt & - \\
\hline S-43 & Diesel Fuel Storage Tank & Exempt & - \\
\hline S-44 & Diesel Fuel Storage Tank & Exempt & - \\
\hline S-45 & Diesel Fuel Storage Tank & Exempt & - \\
\hline S-49 & Cyanide Room Scrubber & Exempt & - \\
\hline S-52 & Horizontal Firetube Boiler & Permitted & $\mathrm{NO}_{\mathrm{x}}, \mathrm{CO}, \mathrm{SO}_{2}, \mathrm{PM}_{10}, \mathrm{VOCs}$ \\
\hline S-53 & Horizontal Firetube Boiler & Permitted & $\mathrm{NO}_{\mathrm{x}}, \mathrm{CO}, \mathrm{SO}_{2}, \mathrm{PM}_{10}, \mathrm{VOCs}$ \\
\hline S-54 & $\begin{array}{l}\text { Near-Zero Emissions (NZE) } \\
\text { Closed-Loop Vapor } \\
\text { Degreaser }\end{array}$ & Permitted & Perchloroethylene \\
\hline S-55 & $\begin{array}{l}\text { BaBar Detector/Drift Cham- } \\
\text { ber }\end{array}$ & Permitted & Isobutane \\
\hline S-56 & $\begin{array}{l}\text { BaBar Detector/Resistive } \\
\text { Plate Chambers }\end{array}$ & Permitted & "H-134a, Isobutane \\
\hline S-57 & Sludge Dryer & Permitted & $\mathrm{Cr}^{+6}, \mathrm{Cu}, \mathrm{Ni}$, other metals \\
\hline S-58 & Solvent Cleaning Tank & Permitted & TCE \\
\hline S-59 & Solvent Cleaning Operations & Permitted & TCA, Ethanol, Acetone \\
\hline S-60 & Ultrasonic Cleaning Tank & Permitted & IPA \\
\hline S-61 & Dynasolve Tank & Permitted & Methylene Chloride \\
\hline G-811 & Gasoline Dispensing Facility & Permitted & Gasoline, Diesel Fuel \\
\hline
\end{tabular}




\subsubsection{Annual Update/Air Toxics/Adhesives Reports}

SLAC submitted its Annual Update to BAAQMD on May 2, 2002. The Annual Update is prepared in response to the BAAQMD "Information Update" request for permitted sources, and covers the previous calendar year. Thus, the Annual Update SLAC submitted in 2002 covered the reporting year 2001.

As part of the BAAQMD annual information request, facilities are also required to review the "Toxic Substances Check List" promulgated by BAAQMD to support the California Air Resources Board's "Air Toxics" program. If facilities emit listed chemicals in quantities greater than the "applicable degree of accuracy" threshold, regardless of whether the emissions originate from a permitted source, facilities have an obligation to report air toxics usage at the same time of their Annual Update. SLAC provided the following air toxics emissions information to BAAQMD as part of its 2001 Annual Update:

- H-134a, used in one of the components of the BaBar Detector, 9710 pounds.

- 3M FC-77 Fluorinert Brand Electronic Liquid (contains perfluorinated compounds) used in heat exchangers for one of the components of the BaBar Detector, 80 gallons (about 1200 pounds).

- R-11, R-12, and R-502, used in the SLAC heating, ventilation, and air (HVAC) equipment, 17, 124, and 11 pounds, respectively.

- Kester AP-20 flux remover (contains tetrachloroethylene and amyl acetate), 1 gallon.

During 2001, BAAQMD adopted changes to Regulation 8, Volatile Organics, Rule 51, Adhesives. SLAC is availing itself of the compliance approach set forth for research facilities in BAAQMD 8-51-502.1, which requires that the facility "track their distribution and use through a centralized information system."

\subsubsection{Asbestos and Demolition Notification Program}

Projects that involve the demolition of existing structures or the management of "regulated asbestos containing material" (RACM) are required to provide 10 days advance notice to BAAQMD per Regulation 11, Hazardous Pollutants, Rule 2, Asbestos Demolition, Renovation, and Manufacturing.

During 2001, evaluations of approximately 17 construction projects were performed and the BAAQMD was notified.

\subsubsection{Annual Facility Inspection}

As sometimes occurs, BAAQMD did not conduct an annual inspection of SLAC in 2001.

\subsubsection{United States Environmental Protection Agency-Implemented Programs}

\subsubsection{National Emission Standards for Hazardous Air Pollutants}

To-date, SLAC has submitted initial notification letters to the Air Division of EPA Region 9 for four halogenated solvent cleaning units regulated under the National Emission Standards for Hazardous Air Pollutants (NESHAP). The semiannual exceedance reports and annual emissions report required under this regulatory program were submitted on time to EPA Region 9. 
No exceedances occurred during the covered reporting periods. The four NESHAP units were operated in accordance with their NESHAP emissions limits during the covered reporting periods.

\subsubsection{Protection of Stratospheric Ozone}

No releases of stratospheric ozone-depleting substances (ODSs) occurred during 2001 that were subject to the release reporting and corrective action requirements in the ODS regulations (40CFR82).

The largest source of historical ODS emissions at SLAC, Source S-4, an open-topped vapor degreaser that used 1,1,1-trichloroethane (TCA), was essentially placed into suspended operations during 2000. This suspension of operations was made possible due to the successful year-round operation of Source S-54, a near-zero emission (NZE) degreaser that used perchloroethylene. SLAC received an environmental quality award from the City of Menlo Park for this successful conversion (see Section 3.2 for more information).

SLAC has two DOE-mandated ODS management objectives.

- By 2005, retrofit or replace $100 \%$ of chillers that have greater than 150 tons of cooling capacity, were manufactured before 1984, and that use Class 1 ODS

- By 2010, eliminate the procurement of all Class 1 ODS

SLAC began work in 2000 on replacing the three chillers necessary to attain the first objective. The work is on schedule and will be completed in 2002.

To achieve the second objective, SLAC expects to complete the following projects:

- Building 117 Chiller Replacement

- Halon Systems Fire Replacement (2 systems)

- Miscellaneous Heating, Ventilation, Air Conditioning (HVAC) Equipment Replacement (approximately 6 small systems)

- TCA Replacement Project, Mechanical Fabrication Department (MFD)

- TCA Replacement Project, Site Engineering and Maintenance Department (SEM)

\subsubsection{Toxics Release Inventory Program}

At SLAC, the Toxic Chemical Release Reporting: Community Right-toKnow program (40 CFR 372), more commonly known as the Toxics Release Inventory (TRI) program, is integrated into the non-radiological air quality program.

Historically, SLAC used the "article" and "structural" reporting exemptions for its usage of lead bricks in shielding design and its varied usages of copper (for items such as beamline components and process water lines). During 2001, following consultation with USEPA, DOE HQ, and Stanford University, SLAC decided that it would no longer use TRI reporting exemptions for lead and copper.

SLAC determined that it had placed a minimum of 15,000 pounds of both lead and copper into service during the reporting year 2000. Since the "otherwise use" threshold quantity for both metals for reporting year 2000 was 10,000 pounds, SLAC prepared Form Rs for the two metals and submitted 
them to the DOE Stanford Site Office (SSO) on June 15, 2001. These two Form Rs represented the first TRI reports filed by SLAC since 1994, when it had filed for sulfuric acid (the form of which SLAC uses was later delisted) and 1,1,1 trichloroethane (which SLAC no longer uses above threshold quantities).

\subsubsection{San Mateo County-Implemented Programs}

SLAC submitted its CalARP registration information to the San Mateo County Department of Health Services (the County) on March 3, 1998. The original registration information was amended on May 15, 1998. The net result was that SLAC registered under the CalARP program for the "Table 3" substances nitric acid and potassium cyanide.

Information received during 1999 from the California Office of Emergency Services (OES) appeared to indicate that SLAC had an excellent case for "de-registering" its use of nitric acid. Additionally, a case can be made for de-registering potassium cyanide based on the way SLAC managed and processed the chemical.

CalARP program regulations for Table 3 substances state that the County is required to make a determination whether a Risk Management Plan (RMP) is required of SLAC for the CalARP-regulated substances SLAC is managing. As of 2001 year-end, the County had not yet made its determination.

If the County makes a determination that a RMP is necessary, the County is required to give SLAC a minimum of 12 months, and a maximum of 36 months, to submit an RMP. In an RMP, SLAC would need to prepare offsite consequence analyses of worst case and alternative release scenarios for its registered CalARP chemicals, accident histories for the registered chemicals, and general descriptions of its accident prevention programs.

\subsubsection{Chemical Information Management System}

The anticipated major change to SLAC operations that will occur when its SMOP permit is granted is that SLAC will be required to switch from its past source-by-source record keeping systems to a facility-wide chemical usage record keeping system. (For more information about the SMOP permit, see Section 3.3.2.1.) In anticipation of this requirement, a 15-member "Chemical User Team" has been meeting regularly at SLAC since early 2000 to conceptualize, design, and implement a new Chemical Information Management System (CIMS).

The Chemical User Team decided on a two-part strategy. A short-term solution was recommended for the next two to three years to track all SLAC chemical purchases. A longterm solution, consisting of a container tracking system, that would support more than fifteen separate ES\&H regulatory compliance programs as well as some SLAC internal business processes, was recommended as the most desirable solution. This long-term solution is now generally referred to as the SLAC CIMS.

During 2001, SLAC achieved the following milestones in its development of a new CIMS.

- On April 27, SLAC entered into a memorandum of understanding (MOU) with the Chemical Strategies Partnership (CSP) to participate in a research effort entitled the Silicon Valley Chemical Management Services Pilot Project. Other participating facilities include Seagate and Analog Devices. The premise of the research is to examine whether facilities can, by restructuring their chemical supply chains, reduce chemical usage and waste at their facilities as well achieve other operational efficiencies. More information on the pilot program is available at:

http://www.chemicalstrategies.org/silicon_valley.htm 
- In July, SLAC, in partnership with CSP, completed a baseline study of its chemical management system and concomitant operating costs.

- In October, laboratory management agreed to pursue the Chemical User Team's recommendation of reaching out to the external vendor community with a "Request for Information" for two types of projects:

- An information system only project

- A project that would consolidate the existing SLAC chemical vendors (250+) into one supply contract, and combine the supply contract with the provision of an information system and related services

- In December, the Chemical User Team finished preparation of its internal white paper entitled Chemical Information Management System: Business Requirements Document, and released it to laboratory management for review.

\subsubsection{Executive Order 13148: Greening the Government}

In response to a request from DOE HQ, SLAC prepared a document entitled Field Validation of 2000 Toxic Chemical Release Inventory (TRI) Data. DOE HQ then used the submitted responses to prepare an annual complex-wide report on the DOE implementation of the EO 13148 requirements. The DOE report for 2001 that includes SLAC data, is available at:

$$
\text { http://tis-nt.eh.doe.gov/oepa }
$$

(select "Environmental Data and Reports," then "Environmental Reports," and then "Executive Order 13148, Second Annual Progress Report, March 2002").

As part of its efforts to implement the "Greening the Government" series of five Executive Orders, the DOE asked SLAC to submit a Pollution Prevention and Energy Efficiency Plan. SLAC submitted this plan in February 2001. The plan contains a variety of facility-specific goals intended for DOE integration into the complex-wide attainment of EO 13148 and the other EOs. Four goals in the plan relate to air quality. Two were previously discussed in Section 3.3.3.2. The others toward which SLAC is working are:

- Reduce releases of toxic chemicals subject to TRI reporting by $90 \%$ by 2005 , using a 1993 baseline.

- Reduce greenhouse gas emissions attributed to facility energy use through life-cycle cost-effective measures by $25 \%$ by 2005 and $30 \%$ by 2010 , using 1990 as a baseline (SLAC proposed to achieve a 4\% reduction by FY05 using FY94 as its baseline).

\subsection{Water Protection Programs}

\subsubsection{Clean Water Act}

The Federal Water Pollution Control Act, also referred to as the Clean Water Act (CWA), was enacted in 1972 to halt the degradation of our nation's waters. The CWA established the National Pollutant Discharge Elimination System, which regulates discharges of wastewater from point sources such as Publicly Owned Treatment Works (POTWs) and categorically regulated industrial facilities such as electroplating shops. In 1987, the CWA was amended to include non-point source discharges such as storm water run-off from industrial, municipal, and construction activities. The CWA is the primary driver behind the SLAC water environmental programs.

\subsubsection{Surface Water}

Federal regulations allow authorized states to issue general permits to regulate industrial storm water or non-point source discharges. California is an authorized state and, in 1991, the State Water Resources Control Board adopted the Industrial Activities Stormwater General Permit (General Permit). SLAC filed a Notice of Intent to comply with the Gen- 
eral Permit. The goal of the General Permit is to reduce pollution in the waters of the state by regulating storm water discharges associated with industrial activities.

The General Permit was re-issued in 1997 and SLAC follows the Storm Water Pollution Prevention Plan (SWPPP). The SWPPP includes the Storm Water Management Program (SWMP) and both generic and specific Best Management Practices (BMPs). The SWMP presents the rationale for sampling, lists the sampling locations, and specifies the analyses to be performed.

In 2001, the SWPPP map of SLAC was updated and the SWMP was revised. The General Permit requires submission of an annual report on storm water activities by July 1 . SLAC transmitted its annual report to the RWQCB in June, 2001. No regulatory concerns were raised by the agency regarding the annual report.

During 2001, work related to the storm water program included:

- Repair of fourteen storm-drain catch basins, completing the final phase of the corrective actions identified in the site-wide inspection of July 1999.

- Removal of several abandoned vehicles from SLAC, including six cars, a delivery van, and a semi-trailer. The trailer was donated to the Jasper Ridge Biological Preserve of Stanford University, adjacent to SLAC.

- Construction of berms around both of the SLAC salvage yards. In addition, funding was requested to install a slit drain spanning the entrance gate to the upper salvage yard. This drain will be installed in September 2002.

- Completion of the erosion control project in the Sector 14 run-on drainage channel. A retaining wall, geotextile, and riprap were installed and the upstream area was regraded to reduce sediment migration.

- Acquisition of a vacuum truck to remove accumulated water (primarily rainwater and groundwater) from containments, vaults and sumps throughout SLAC. The water collected is filtered and re-used in the cooling tower system. This process reduces both the amount of supply water needed for cooling and the volume of wastewater discharged to the sanitary sewer. During 2001, approximately 128,000 gallons were recycled using this system.

Per the General Permit, requirements for the Storm Water Monitoring Program include:

- Sampling of two storm events during the wet season

- Monthly visual observations during the wet season

- Quarterly visual observations during the dry season

- Annual Comprehensive Site Compliance Evaluation

All items were completed and results submitted with the Annual Storm Water Report.

Whereas industrial wastewater programs specify quantitative discharge limits for various substances, storm water protection programs implement BMPs to minimize runoff concentrations. The BMPs have been implemented.

As documented in the revised SWMP, the number of monitoring locations increased from four to eight, and samples were filtered to determine both total and dissolved concentrations of metals and other parameters. Of the eight monitoring locations designated for the 2001-2002 wet season, six employed automated samplers and two were sampled manually. Sampling locations are shown in Figure 3-2. 


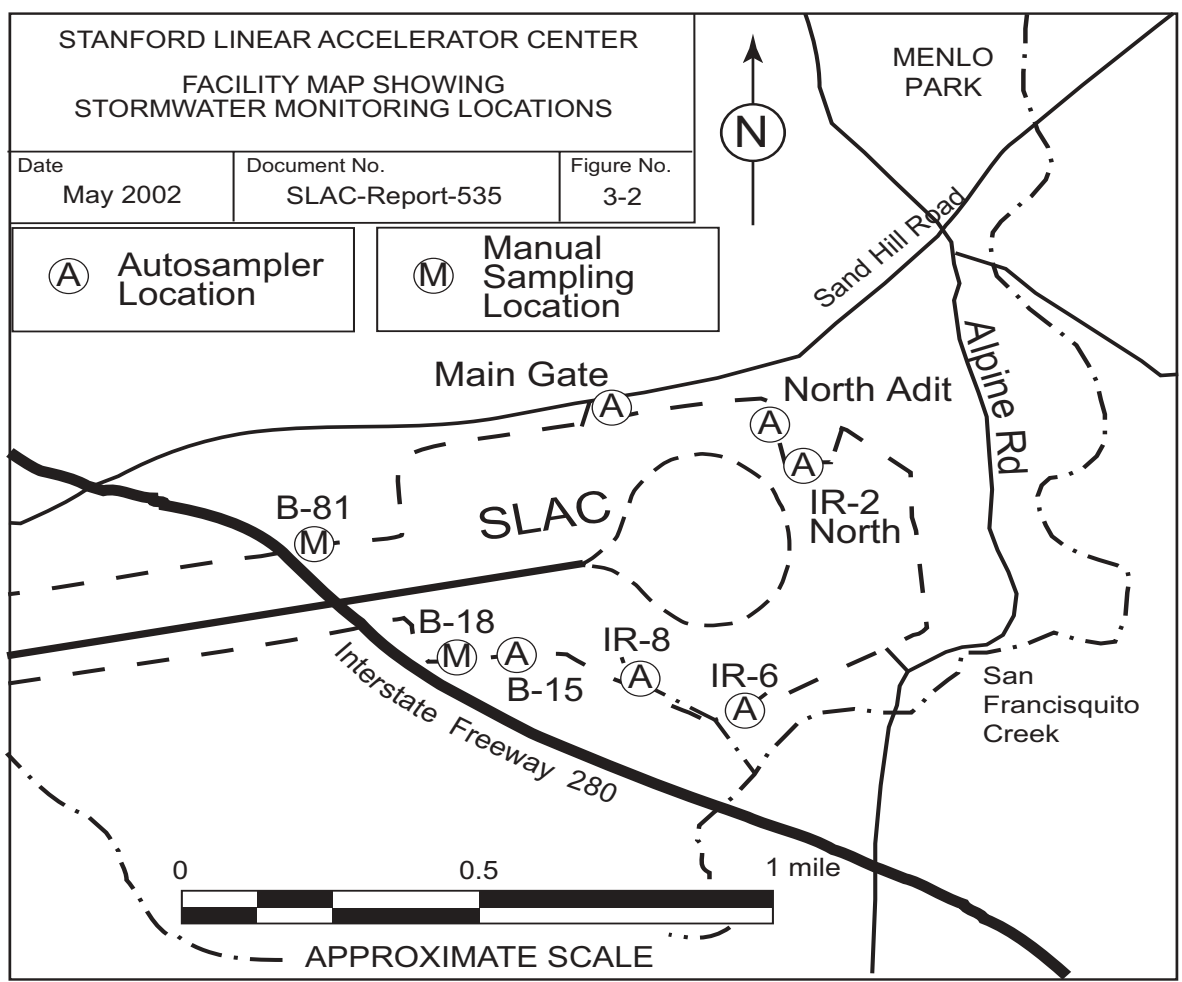

Figure 3-2 SLAC Autosampler Locations

The regulatory wet season begins on October 1 and ends on May 31. To report storm water data for the wet season in a logical and consistent manner, results from both monitored storm events are included in this document, even though the second event occurred in February of 2002.

For the 2001-2002 wet season, SLAC analyzed storm water samples for various constituents. In addition, total dissolved solids, total suspended solids, settleable solids and turbidity were measured for comparative purposes. Analytical results are presented in Table 3-2, Table 3-3, and Table 3-4. SLAC is in compliance with the General Permit.

Each of eight sampling locations was monitored for Polychlorinated Biphenyls (PCBs). Two detectable concentrations were measured in unfiltered samples from the second storm event at IR-6 and IR-8. These concentrations were $0.0016 \mathrm{mg} / \mathrm{L}$ and $0.00033 \mathrm{mg} / \mathrm{L}$, respectively. 
Table 3-2 Stormwater Data for 2001-2002 Sampling and Analysis (part 1 of 4)

\begin{tabular}{|c|c|c|c|c|c|c|c|c|}
\hline \multirow{4}{*}{$\begin{array}{c}\text { 2001-2002 } \\
\text { Wet Season } \\
\text { Summary } \\
\text { Sample Type }\end{array}$} & \multicolumn{4}{|c|}{ Main Gate } & \multicolumn{4}{|c|}{ North Adit } \\
\hline & \multicolumn{2}{|c|}{ 1st Storm Event } & \multicolumn{2}{|c|}{ 2nd Storm Event } & \multicolumn{2}{|c|}{ 1st Storm Event } & \multicolumn{2}{|c|}{ 2nd Storm Event } \\
\hline & \multicolumn{2}{|c|}{30 October 2001} & \multicolumn{2}{|c|}{7 February 2002} & \multicolumn{2}{|c|}{30 October 2001} & \multicolumn{2}{|c|}{7 February 2002} \\
\hline & Unfiltered & Filtered & Unfiltered & Filtered & Unfiltered & Filtered & Unfiltered & Filtered \\
\hline \multicolumn{9}{|l|}{ METALS } \\
\hline Aluminum & 0.52 & 0.19 & 0.16 & $<0.050$ & 3.0 & $<0.050$ & 0.86 & 0.092 \\
\hline Arsenic & $<0.0020$ & $<0.0020$ & $<0.0020$ & $<0.0020$ & $<0.0020$ & $<0.0020$ & $<0.0020$ & $<0.0020$ \\
\hline Cadmium & NLS & NLS & NLS & NLS & NLS & NLS & NLS & NLS \\
\hline Chromium & 0.0030 & 0.0019 & 0.0044 & 0.0029 & NLS & NLS & NLS & NLS \\
\hline Copper & 0.013 & 0.010 & 0.0062 & 0.0064 & 0.036 & 0.007 & 0.011 & 0.0069 \\
\hline Iron & 0.88 & 0.29 & 0.44 & 0.12 & 5.6 & 0.13 & 1.6 & 0.13 \\
\hline Lead & 0.014 & 0.0038 & $<0.0020$ & $<0.0020$ & 0.045 & $<0.0040$ & 0.0081 & $<0.0020$ \\
\hline Manganese & NLS & NLS & NLS & NLS & 0.91 & 0.011 & 0.11 & $<0.010$ \\
\hline Molybdenum & NLS & NLS & NLS & NLS & NLS & NLS & NLS & NLS \\
\hline Nickel & NLS & NLS & NLS & NLS & NLS & NLS & NLS & NLS \\
\hline Silver & NLS & NLS & NLS & NLS & NLS & NLS & NLS & NLS \\
\hline Zinc & 0.078 & 0.049 & 0.13 & 0.037 & 0.53 & 0.027 & 0.11 & 0.058 \\
\hline \multicolumn{9}{|l|}{ NON-METALS } \\
\hline $\mathrm{pH}$ (unitless) & 7.32 & NA & 7.71 & 7.55 & 7.83 & $\mathrm{NA}$ & 7.94 & 7.71 \\
\hline $\begin{array}{l}\text { Polychlorinated } \\
\text { Biphenyls (PCBs) }\end{array}$ & $<0.0002$ & $<0.0002$ & $<0.0002$ & $<0.0002$ & $<0.0002$ & $<0.0002$ & $<0.0002$ & $<0.0002$ \\
\hline $\begin{array}{l}\text { Total Organic } \\
\text { Carbon (TOC) }\end{array}$ & 28 & NA & 18 & 17 & 28 & NA & 19 & 18 \\
\hline $\begin{array}{l}\text { Total Suspended } \\
\text { Solids (TSS) }\end{array}$ & 120 & NA & 35 & NA & 630 & NA & 180 & NA \\
\hline $\begin{array}{l}\text { Total Dissolved } \\
\text { Solids (TDS) }\end{array}$ & 230 & NA & 1,200 & NA & 1,400 & NA & 1,200 & NA \\
\hline $\begin{array}{l}\text { Settleable Solids } \\
(\mathrm{ml} / \mathrm{L} / \mathrm{hr})\end{array}$ & 0.41 & NA & 0.20 & NA & 5.2 & NA & 1.0 & NA \\
\hline $\begin{array}{l}\text { Turbidity } \\
\text { (NTU) }\end{array}$ & 50 & NA & 6.7 & NA & 37 & NA & 30 & NA \\
\hline $\begin{array}{l}\text { Specific } \\
\text { Conductance } \\
\text { (umho/cm) }\end{array}$ & 220 & NA & 1,500 & 1,500 & 1,600 & NA & 1,400 & 1,400 \\
\hline Tritium (pCi/l) & NDA & $\mathrm{NA}$ & NDA & $\mathrm{NA}$ & NDA & NA & NDA & NA \\
\hline
\end{tabular}

Notes:

All analyses (except as indicated below) are performed off-site by contract lab (CLS in Rancho Cordova, CA) Tritium analysis performed in house by SLAC health physics personnel

$\mathrm{ml} / \mathrm{l} / \mathrm{hr}=$ milliliters per liter per hour

All values in milligrams per liter $(\mathrm{mg} / \mathrm{l})$ unless otherwise noted

NTU $=$ Nephelometer Turbidity Units

umho/cm = micromhos per centimeter

$\mathrm{pCi} / \mathrm{l}=$ picocuries per liter

"<" symbol precedes reporting limit (i.e., analyte not detected)

$\mathrm{NLS}=$ no longer sampled per Sec. B(5) (c) (ii) of General Permit

$\mathrm{NA}=$ Not analyzed

NDA $=$ no detectable (radiological) activity above background

Filtered samples passed through 0.45-micron filter 
Table 3-3 Stormwater Data for 2001-2002 Sampling and Analysis (part 2 of 4)

\begin{tabular}{|c|c|c|c|c|c|c|c|c|}
\hline \multirow{4}{*}{$\begin{array}{c}\text { 2001-2002 } \\
\text { Wet Season } \\
\text { Summary } \\
\text { Sample Type }\end{array}$} & \multicolumn{4}{|c|}{ IR-6 } & \multicolumn{4}{|c|}{ IR-8 } \\
\hline & \multicolumn{2}{|c|}{ 1st Storm Event } & \multicolumn{2}{|c|}{ 2nd Storm Event } & \multicolumn{2}{|c|}{ 1st Storm Event } & \multicolumn{2}{|c|}{ 2nd Storm Event } \\
\hline & \multicolumn{2}{|c|}{30 October 2001} & \multicolumn{2}{|c|}{7 February 2002} & \multicolumn{2}{|c|}{30 October 2001} & \multicolumn{2}{|c|}{7 February 2002} \\
\hline & Unfiltered & Filtered & Unfiltered & Filtered & Unfiltered & Filtered & Unfiltered & Filtered \\
\hline \multicolumn{9}{|l|}{ METALS } \\
\hline Aluminum & 0.39 & 0.13 & 0.42 & 0.077 & 5.3 & $<0.050$ & 2.5 & 0.22 \\
\hline Arsenic & 0.017 & 0.016 & 0.0041 & 0.0041 & 0.0043 & 0.0024 & 0.0055 & 0.0041 \\
\hline Cadmium & NLS & NLS & NLS & NLS & NLS & NLS & NLS & NLS \\
\hline Chromium & NLS & NLS & NLS & NLS & NLS & NLS & NLS & NLS \\
\hline Copper & 0.084 & 0.072 & 0.047 & 0.035 & 0.26 & 0.021 & 0.052 & 0.015 \\
\hline Iron & 0.89 & 0.33 & 0.61 & 0.11 & 7.9 & 0.28 & 2.7 & 0.31 \\
\hline Lead & 0.008 & 0.0024 & 0.0095 & $<0.0020$ & 0.081 & $<0.0040$ & 0.025 & $<0.0020$ \\
\hline Manganese & 0.081 & 0.034 & 0.021 & 0.017 & 1.1 & 0.60 & 0.28 & 0.11 \\
\hline Molybdenum & NLS & NLS & NLS & NLS & NLS & NLS & NLS & NLS \\
\hline Nickel & NLS & NLS & NLS & NLS & NLS & NLS & NLS & NLS \\
\hline Silver & NLS & NLS & NLS & NLS & NLS & NLS & NLS & NLS \\
\hline Zinc & 0.49 & 0.32 & 0.39 & 0.15 & 2.3 & 0.066 & 0.46 & 0.11 \\
\hline \multicolumn{9}{|l|}{ NON-METALS } \\
\hline $\mathrm{pH}$ (unitless) & 7.20 & $\mathrm{NA}$ & 7.73 & 7.47 & 7.54 & NA & 7.65 & 7.42 \\
\hline \begin{tabular}{|l|} 
Polychlorinated \\
Biphenyls (PCBs)
\end{tabular} & $<0.0002$ & $<0.0002$ & $0.0016^{*}$ & $<0.0002$ & $<0.0002$ & $<0.0002$ & $0.00033^{*}$ & $<0.0002$ \\
\hline $\begin{array}{l}\text { Total Organic } \\
\text { Carbon (TOC) }\end{array}$ & 27 & NA & 16 & 14 & 79 & NA & 19 & 17 \\
\hline $\begin{array}{l}\text { Total Suspended } \\
\text { Solids (TSS) }\end{array}$ & 46 & NA & 22 & NA & 1,000 & NA & 320 & NA \\
\hline $\begin{array}{l}\text { Total Dissolved } \\
\text { Solids (TDS) } \\
\end{array}$ & 120 & NA & 290 & NA & 1,700 & NA & 330 & NA \\
\hline $\begin{array}{l}\text { Settleable Solids } \\
(\mathrm{ml} / \mathrm{L} / \mathrm{hr})\end{array}$ & 0.62 & NA & $<0.10$ & NA & 11 & NA & 1.8 & NA \\
\hline \begin{tabular}{|l} 
Turbidity \\
(NTU)
\end{tabular} & 23 & NA & 21 & NA & 17 & NA & 37 & NA \\
\hline $\begin{array}{l}\text { Specific } \\
\text { Conductance } \\
\text { (umho/cm) }\end{array}$ & 470 & NA & 360 & 370 & 160 & NA & 420 & 410 \\
\hline Tritium (pCi/l) & NDA & NA & NDA & NA & NDA & $\mathrm{NA}$ & NDA & $\mathrm{NA}$ \\
\hline
\end{tabular}

Notes:

All analyses (except as indicated below) are performed off-site by contract lab (CLS in Rancho Cordova, CA)

Tritium analysis performed in house by SLAC health physics personnel

All values in milligrams per liter $(\mathrm{mg} / \mathrm{l})$ unless otherwise noted

$\mathrm{ml} / / \mathrm{hr}=$ milliliters per liter per hour

NTU = Nephelometer Turbidity Units

umho/cm = micromhos per centimeter

$\mathrm{pCi} / \mathrm{l}=$ picocuries per liter

"<" symbol precedes reporting limit (i.e., analyte not detected)

$\mathrm{NLS}=$ no longer sampled per Sec. B(5) (c) (ii) of General Permit

NA $=$ Not analyzed

$\mathrm{NDA}=$ no detectable (radiological) activity above background

* = Aroclor 1260 was only PCB compound detected

Filtered samples passed through 0.45-micron filter 
Table 3-4 Stormwater Data for 2001-2002 Sampling and Analysis (part 3 of 4)

\begin{tabular}{|c|c|c|c|c|c|c|c|c|}
\hline \multirow{4}{*}{\begin{tabular}{|c}
$\begin{array}{c}2001-2002 \\
\text { Wet Season } \\
\text { Summary }\end{array}$ \\
Sample Type \\
\end{tabular}} & \multicolumn{4}{|c|}{ IR-2 North } & \multicolumn{4}{|c|}{ Bldg. 15} \\
\hline & \multicolumn{2}{|c|}{ 1st Storm Event } & \multicolumn{2}{|c|}{ 2nd Storm Event } & \multicolumn{2}{|c|}{ 1st Storm Event } & \multicolumn{2}{|c|}{ 2nd Storm Event } \\
\hline & \multicolumn{2}{|c|}{30 October 2001} & \multicolumn{2}{|c|}{7 February 2002} & \multicolumn{2}{|c|}{30 October 2001} & \multicolumn{2}{|c|}{7 February 2002} \\
\hline & Unfiltered & Filtered & Unfiltered & Filtered & Unfiltered & Filtered & Unfiltered & Filtered \\
\hline \multicolumn{9}{|l|}{ METALS } \\
\hline Aluminum & 0.95 & 0.062 & 0.94 & 0.075 & 0.21 & 0.05 & 1.6 & 0.19 \\
\hline Arsenic & $<0.0020$ & $<0.0020$ & $<0.0020$ & $<0.0020$ & $<0.0020$ & $<0.0020$ & $<0.0020$ & $<0.0020$ \\
\hline Cadmium & $<0.0010$ & $<0.0010$ & $<0.0010$ & $<0.0010$ & $<0.0010$ & $<0.0010$ & 0.0017 & $<0.0010$ \\
\hline Chromium & 0.0036 & 0.0016 & 0.0033 & 0.0016 & $<0.0010$ & $<0.0010$ & 0.0036 & 0.0012 \\
\hline Copper & 0.015 & 0.0064 & 0.013 & 0.0092 & 0.020 & 0.017 & 0.019 & 0.0055 \\
\hline Iron & 1.6 & 0.18 & 1.2 & 0.10 & 0.17 & $<0.10$ & 1.7 & 0.23 \\
\hline Lead & 0.025 & $<0.0020$ & 0.0082 & $<0.0020$ & 0.0029 & $<0.0020$ & 0.023 & $<0.0020$ \\
\hline Manganese & 0.14 & 0.028 & 0.087 & $<0.010$ & 0.025 & $=0.010$ & 0.088 & 0.024 \\
\hline Molybdenum & $<0.010$ & $<0.010$ & $<0.010$ & $<0.010$ & $<0.010$ & $<0.010$ & $<0.010$ & $<0.010$ \\
\hline Nickel & 0.017 & 0.014 & 0.013 & $<0.010$ & $<0.005$ & $<0.005$ & 0.012 & $<0.010$ \\
\hline Silver & $<0.0010$ & $<0.0010$ & $<0.0010$ & $<0.0010$ & $<0.0010$ & $<0.0010$ & $<0.0010$ & $<0.0010$ \\
\hline Zinc & 0.26 & 0.092 & 0.14 & 0.047 & 1.20 & 0.012 & 0.46 & 0.046 \\
\hline \multicolumn{9}{|l|}{ NON-METALS } \\
\hline $\mathrm{pH}$ (unitless) & 7.45 & $\mathrm{NA}$ & 7.88 & 7.59 & 7.03 & NA & 7.69 & 7.36 \\
\hline $\begin{array}{l}\text { Polychlorinated } \\
\text { Biphenyls (PCBs) }\end{array}$ & $<0.0002$ & $<0.0002$ & $<0.0002$ & $<0.0002$ & $<0.0002$ & $<0.0002$ & $<0.0002$ & $<0.0002$ \\
\hline $\begin{array}{l}\text { Total Organic } \\
\text { Carbon (TOC) }\end{array}$ & 35 & NA & 19 & 18 & 19 & NA & 7.0 & 5.2 \\
\hline \begin{tabular}{|l|} 
Total Suspended \\
Solids (TSS)
\end{tabular} & 220 & NA & 130 & NA & 10 & NA & 210 & NA \\
\hline $\begin{array}{l}\text { Total Dissolved } \\
\text { Solids (TDS) } \\
\end{array}$ & 440 & NA & 360 & NA & 66 & NA & 60 & NA \\
\hline $\begin{array}{l}\text { Settleable Solids } \\
(\mathrm{ml} / \mathrm{L} / \mathrm{hr})\end{array}$ & 1.3 & NA & 0.40 & NA & $<0.20$ & NA & 0.60 & NA \\
\hline \begin{tabular}{|l}
$\begin{array}{l}\text { Turbidity } \\
\text { (NTU) }\end{array}$ \\
\end{tabular} & 45 & NA & 32 & NA & 13 & NA & 52 & NA \\
\hline $\begin{array}{l}\text { Specific } \\
\text { Conductance } \\
\text { (umho/cm) }\end{array}$ & 1,600 & NA & 430 & 410 & 77 & NA & 74 & 78 \\
\hline Tritium (pCi/l) & NDA & NA & NDA & NA & NDA & NA & NDA & NA \\
\hline
\end{tabular}

Notes:

All analyses (except as indicated below) are performed off-site by contract lab (CLS in Rancho Cordova, CA) Tritium analysis performed in house by SLAC health physics personnel

All values in milligrams per liter $(\mathrm{mg} / \mathrm{l})$ unless otherwise noted

$\mathrm{ml} / \mathrm{l} / \mathrm{hr}=$ milliliters per liter per hour

NTU = Nephelometer Turbidity Units

umho/cm = micromhos per centimeter

$\mathrm{pCi} / \mathrm{l}=$ picocuries per liter

"<" symbol precedes reporting limit (i.e., analyte not detected)

$\mathrm{NA}=$ Not analyzed

NDA = no detectable (radiological) activity above background

Filtered samples passed through 0.45-micron filter 
Table 3-5 Stormwater Data for 2001-2002 Sampling and Analysis (part 4 of 4)

\begin{tabular}{|c|c|c|c|c|c|c|c|c|}
\hline \multirow{4}{*}{$\begin{array}{c}\begin{array}{c}2001-2002 \\
\text { Wet Season } \\
\text { Summary }\end{array} \\
\text { Sample Type } \\
\end{array}$} & \multicolumn{4}{|c|}{ Bldg. 18} & \multicolumn{4}{|c|}{ Bldg. 81} \\
\hline & \multicolumn{2}{|c|}{ 1st Storm Event } & \multicolumn{2}{|c|}{ 2nd Storm Event } & \multicolumn{2}{|c|}{ 1st Storm Event } & \multicolumn{2}{|c|}{ 2nd Storm Event } \\
\hline & \multicolumn{2}{|c|}{30 October 2001} & \multicolumn{2}{|c|}{7 February 2002} & \multicolumn{2}{|c|}{30 October 2001} & \multicolumn{2}{|c|}{7 February 2002} \\
\hline & Unfiltered & Filtered & Unfiltered & Filtered & Unfiltered & Filtered & Unfiltered & Filtered \\
\hline \multicolumn{9}{|l|}{ METALS } \\
\hline Aluminum & 1.4 & 0.22 & 0.57 & $<0.050$ & 0.51 & 0.15 & 0.90 & 0.19 \\
\hline Arsenic & $<0.0020$ & $<0.0020$ & $<0.0020$ & $<0.0020$ & $<0.0020$ & $<0.0020$ & $<0.0020$ & $<0.0020$ \\
\hline Cadmium & $<0.0010$ & $<0.0010$ & 0.011 & $<0.0010$ & $<0.0010$ & $<0.0010$ & $<0.0010$ & 0.0012 \\
\hline Chromium & 0.0016 & $<0.0010$ & 0.0036 & 0.0012 & 0.0035 & 0.0021 & 0.0084 & 0.0035 \\
\hline Copper & 0.018 & 0.012 & 0.024 & 0.010 & 0.018 & 0.011 & 0.026 & 0.014 \\
\hline Iron & 0.93 & 0.22 & 0.98 & 0.22 & 0.65 & 0.22 & 1.3 & 0.26 \\
\hline Lead & 0.010 & $<0.0020$ & 0.026 & $<0.0020$ & 0.019 & 0.0058 & 0.046 & 0.0062 \\
\hline Manganese & 0.11 & $<0.010$ & 0.065 & $<0.010$ & 0.99 & 0.058 & 0.10 & 0.034 \\
\hline Molybdenum & $<0.010$ & $<0.010$ & $<0.010$ & $<0.010$ & $<0.010$ & $<0.010$ & $<0.010$ & $<0.010$ \\
\hline Nickel & 0.010 & 0.0061 & $<0.010$ & $<0.010$ & 0.0093 & 0.007 & $<0.010$ & $<0.010$ \\
\hline Silver & $<0.0010$ & $<0.0010$ & $<0.0010$ & $<0.0010$ & $<0.0010$ & $<0.0010$ & $<0.0010$ & $<0.0010$ \\
\hline Zinc & 0.11 & 0.062 & 0.22 & 0.017 & 0.21 & 0.11 & 0.24 & 0.10 \\
\hline \multicolumn{9}{|l|}{ NON-METALS } \\
\hline $\mathrm{pH}$ (unitless) & 6.98 & $\mathrm{NA}$ & 7.35 & 7.14 & 7.06 & $\mathrm{NA}$ & 7.71 & 7.48 \\
\hline $\begin{array}{l}\text { Polychlorinated } \\
\text { Biphenyls (PCBs) }\end{array}$ & $<0.0002$ & $<0.0002$ & $<0.0002$ & $<0.0002$ & $<0.0002$ & $<0.0002$ & $<0.0002$ & $<0.0002$ \\
\hline $\begin{array}{l}\text { Total Organic } \\
\text { Carbon (TOC) }\end{array}$ & 20 & NA & 13 & 11 & 22 & $\mathrm{NA}$ & 37 & 27 \\
\hline $\begin{array}{l}\text { Total Suspended } \\
\text { Solids (TSS) }\end{array}$ & 240 & $\mathrm{NA}$ & 120 & NA & 210 & $\mathrm{NA}$ & 170 & NA \\
\hline $\begin{array}{l}\text { Total Dissolved } \\
\text { Solids (TDS) }\end{array}$ & 76 & $\mathrm{NA}$ & 36 & $\mathrm{NA}$ & 170 & $\mathrm{NA}$ & 200 & NA \\
\hline $\begin{array}{l}\text { Settleable Solids } \\
(\mathrm{m} / \mathrm{L} / \mathrm{hr})\end{array}$ & 0.9 & $\mathrm{NA}$ & 0.80 & NA & 2.2 & $\mathrm{NA}$ & 1.2 & NA \\
\hline $\begin{array}{l}\text { Turbidity } \\
\text { (NTU) }\end{array}$ & 45 & $\mathrm{NA}$ & 24 & NA & 17 & $\mathrm{NA}$ & 37 & NA \\
\hline $\begin{array}{l}\text { Specific } \\
\text { Conductance } \\
\text { (umho/cm) }\end{array}$ & 45 & $\mathrm{NA}$ & 37 & 44 & 170 & NA & 210 & 220 \\
\hline Tritium (pCi/l) & NDA & $\mathrm{NA}$ & NDA & $\mathrm{NA}$ & NDA & $\mathrm{NA}$ & NDA & $\mathrm{NA}$ \\
\hline
\end{tabular}

Notes:

All analyses (except as indicated below) are performed off-site by contract lab (CLS in Rancho Cordova, CA) Tritium analysis performed in house by SLAC health physics personnel

All values in milligrams per liter (mg/l) unless otherwise noted

$\mathrm{ml} / \mathrm{l} / \mathrm{hr}=$ milliliters per liter per hour

NTU = Nephelometer Turbidity Units

umho/cm = micromhos per centimeter

$\mathrm{pCi} / \mathrm{l}=$ picocuries per liter

"<" symbol precedes reporting limit (i.e., analyte not detected)

$\mathrm{NA}=$ Not analyzed

NDA = no detectable (radiological) activity above background

Filtered samples passed through 0.45-micron filter 


\subsubsection{Industrial and Sanitary Wastewater}

SLAC operated under three Mandatory Wastewater Discharge Permits in 2001. These permits set discharge limits for the sanitary sewer and went into effect on April 1, 1997. The permits will expire March 31, 2002. In 2001, SLAC complied with all applicable sampling and signage requirements. In addition, the analytical results were within permitted concentration limits.

The SLAC wastewater discharge permits were:

- WB 970401-F, which regulates SLAC as a whole, including industrial and sanitary wastewaters.

- WB 970401-P, which regulates operations at the Rinse Water Treatment Plant (RWTP).

- WB 970401-HX, which regulates operations at the Batch Treatment Plant (BTP).

Permit requirements for SLAC included:

- Semi-annual sampling for seven heavy metals, Total Toxic Organics (TTO), and pH at the RWTP.

- Semi-annual sampling for cyanide at the final rinse tank for the Plating Shop cyanide treatment tank.

- Semi-annual sampling for seven heavy metals, Total Toxic Organics (TTO), and pH at the BTP.

- Signs posted throughout the site advising personnel not to discharge non-permitted material to the sanitary sewer and providing emergency response numbers should there be an accidental release.

- Quarterly sampling for seven heavy metals and pH at the Sand Hill Road Flow Meter Station.

SLAC complied with all applicable sampling and signage requirements. In addition, the analytical results were within permitted concentration limits.

SLAC discharged a total of 15,981,411 gallons of wastewater to the sanitary sewer system in 2001 , an average of 43,785 gallons per day.

The SLAC Sanitary Wastewater Monitoring Program consists of the following three permits:

\subsubsection{Total Facility Discharge Permit}

The Total Facility Discharge Permit (Permit No. WB 970401-F) covers the SLAC total contribution to the sanitary sewer, including the combined flow from the RWTP and all other on-site wastewater discharges.

SBSA monitored the discharge quarterly in 2001 to ensure compliance with the permit. SLAC split samples with SBSA during these monitoring events and analyzed them to compare results for quality assurance purposes. All analytical results from samples collected in 2001 are presented in Table 3-6. All analytical results are within permitted limits. 
Table 3-6 2001 Flow Meter Station Sampling Data

\begin{tabular}{|c|c|c|c|c|c|c|c|c|c|}
\hline \multirow[b]{2}{*}{ Parameter } & \multirow[b]{2}{*}{$\begin{array}{c}\text { Wastewater } \\
\text { Discharge } \\
\text { Limit }^{1} \\
\text { (Ib/day) }\end{array}$} & \multicolumn{4}{|c|}{ August 15, 2001} & \multicolumn{4}{|c|}{ December 12, 2001} \\
\hline & & $\begin{array}{c}\text { SLAC } \\
\text { Monitoring } \\
\text { Results } \\
\text { (mg/L) }\end{array}$ & $\begin{array}{c}\text { SBSA } \\
\text { Monitoring } \\
\text { Results } \\
\text { (mg/L) }\end{array}$ & $\begin{array}{c}\text { SLAC } \\
\text { Calculated } \\
\text { Results }^{2} \\
\text { (Ib/day) }\end{array}$ & $\begin{array}{l}\text { SBSA } \\
\text { Calculated } \\
\text { Results } \\
\text { (Ib/day) }\end{array}$ & $\begin{array}{c}\text { SLAC } \\
\text { Monitoring } \\
\text { Results } \\
\text { (mg/L) }\end{array}$ & $\begin{array}{c}\text { SBSA } \\
\text { Monitoring } \\
\text { Results } \\
(\mathrm{mg} / \mathrm{L})\end{array}$ & $\begin{array}{c}\text { SLAC } \\
\text { Calculated } \\
\text { Results } \\
\text { (lb/day) }\end{array}$ & $\begin{array}{l}\text { SBSA } \\
\text { Calculated } \\
\text { Results } \\
\text { (lb/day) }\end{array}$ \\
\hline Cadmium & 0.036 & $\overline{c<0.0010^{3}}$ & $<0.0100$ & 0.0003 & $<0.00344$ & 0.0130 & $<0.0100$ & 0.0083 & $<0.0064$ \\
\hline Chromium & 0.48 & 0.012 & $<0.0700$ & 0.0041 & $<0.02411$ & 0.0033 & $<0.0700$ & 0.0021 & $<0.0446$ \\
\hline Copper & 0.35 & 0.044 & 0.0600 & 0.0151 & 0.02067 & 0.060 & 0.1400 & 0.0382 & 0.0893 \\
\hline Lead & 0.33 & 0.0039 & $<0.0800$ & 0.0013 & $<0.02756$ & $<0.020$ & $<0.0800$ & 0.0127 & $<0.0510$ \\
\hline Nickel & 0.064 & 0.026 & $<0.0400$ & 0.0090 & $<0.01378$ & 0.028 & 0.0600 & 0.0178 & 0.0383 \\
\hline Silver & 0.076 & $<0.0010$ & $<0.0080$ & 0.0003 & $<0.00276$ & $<0.001$ & $<0.0080$ & 0.0006 & $<0.0051$ \\
\hline Zinc & 0.7 & 0.11 & 0.1110 & 0.0379 & 0.03824 & 0.13 & 0.1430 & 0.0828 & 0.0912 \\
\hline $\mathrm{pH}$ (unitless) & $6.0-12.5^{4}$ & 8.00 & 8.10 & 8.00 & 8.10 & 8.30 & 8.60 & 8.30 & 8.60 \\
\hline \multirow[t]{2}{*}{ Flow (gpd) } & 62,175 & \multicolumn{4}{|c|}{41,282} & \multicolumn{4}{|c|}{76,413} \\
\hline & & \multicolumn{4}{|c|}{ January 24, 2001} & \multicolumn{4}{|c|}{ June 12, 2001} \\
\hline Cadmium & 0.036 & $<0.0021$ & $<0.0100$ & 0.0007 & $<0.0032$ & 0.0015 & $<0.0100$ & 0.0004 & $<0.0030$ \\
\hline Chromium & 0.48 & 0.0089 & $<0.0700$ & 0.0028 & $<0.022$ & 0.0043 & $<0.700$ & 0.0013 & $<0.0208$ \\
\hline Copper & 0.35 & 0.088 & 0.1300 & 0.028 & 0.0410 & 0.056 & 0.1400 & 0.0166 & 0.0416 \\
\hline Lead & 0.33 & 0.0095 & $<0.0800$ & 0.0030 & $<0.025$ & 0.012 & $<0.0800$ & 0.0036 & $<0.0238$ \\
\hline Nickel & 0.064 & 0.033 & 0.0400 & 0.010 & $<0.013$ & 0.045 & 0.0400 & 0.0134 & 0.0119 \\
\hline Silver & 0.076 & 0.0015 & $<0.0080$ & 0.0005 & $<0.0025$ & 0.0013 & 0.0120 & 0.0004 & 0.0036 \\
\hline Zinc & 0.7 & 0.14 & 0.1390 & 0.044 & 0.0438 & 0.15 & 0.1920 & 0.0445 & 0.0570 \\
\hline $\mathrm{pH}$ & $6.0-12.5$ & 8.24 & 8.60 & NA & NA & 7.76 & 7.90 & 7.76 & 7.90 \\
\hline Flow (gpd) & 62,175 & \multicolumn{4}{|c|}{37,790} & \multicolumn{4}{|c|}{35,579} \\
\hline
\end{tabular}

1 Wastewater Discharge Limit = SBSA Annual Average Limit (compared to the average of four consecutive quarterly samples collected under the current permit)

2 Calculated Results in $\mathrm{lb} / \mathrm{day}=(\mathrm{gal} / \mathrm{day})(\mathrm{mg} / \mathrm{l}$ pollutant $)(8.34 \mathrm{lb} / \mathrm{gal})\left(10^{-6} \mathrm{l} / \mathrm{mg}\right)$

3 " $<$ "symbol precedes a Reporting Limit (RL), which is used in calculations.

$4 \mathrm{pH}$ is regulated as an acceptable range of values, rather than as an Annual Average Limit 


\subsubsection{Rinse Water Treatment Plant (Permit No. WB 970401-P)}

SLAC conducted metal finishing operations in an on-site electroplating shop during 2001. Rinsewater baths from the Plating Shop were processed through the RWTP prior to being discharged to the sanitary sewer. The RWTP discharged 667,052 gallons of effluent to the sanitary sewer in 2001. Effluent from the RWTP consistently met required federal metal finishing pre-treatment standards, which were specified in the permit.

As required by federal standards, SBSA periodically monitored the metal finishing discharges, as well as the rinsewater from a cyanide treatment process in the Plating Shop. Again, SLAC and SBSA split samples from the RWTP and cyanide tank for quality assurance purposes. SBSA and SLAC analytical results for 2001 are presented in Table 3-7. The results indicated that SLAC continued to operate in compliance with applicable regulations.

Table 3-7 2001 Rinse Water Treatment Plant Sampling Data

\begin{tabular}{|c|c|c|c|c|c|c|c|c|}
\hline \multirow[b]{3}{*}{$\begin{array}{l}\text { Analytical } \\
\text { Parameter }\end{array}$} & \multicolumn{2}{|l|}{001} & \multirow{2}{*}{\multicolumn{2}{|c|}{$\begin{array}{c}\text { SLAC-Initiated } \\
\text { Semi-Annual } \\
\text { Sampling }\end{array}$}} & \multirow{2}{*}{\multicolumn{2}{|c|}{$\begin{array}{c}\text { SBSA-Initiated } \\
\text { Annual Sampling } \\
\text { August } 10\end{array}$}} & \multirow{2}{*}{\multicolumn{2}{|c|}{$\begin{array}{c}\text { SLAC-Initiated } \\
\begin{array}{c}\text { Semi-Annual } \\
\text { Sampling }\end{array} \\
\text { December } 11\end{array}$}} \\
\hline & \multirow[b]{2}{*}{$\begin{array}{l}\text { Federal } \\
\text { Daily } \\
\text { Maximum } \\
(\mathrm{mg} / \mathrm{L})\end{array}$} & \multirow[b]{2}{*}{$\begin{array}{c}\text { Federal } \\
\text { Monthly } \\
\text { Average } \\
\text { (mg/L) }\end{array}$} & & & & & & \\
\hline & & & SLAC & SBSA & SLAC & SBSA & SLAC & SBSA \\
\hline \multicolumn{9}{|c|}{ Metals $\left(\mathrm{mg} / \mathrm{L}^{1}\right)$} \\
\hline Cadmium & 0.69 & 0.26 & $<0001^{2}$ & $\mathrm{NS}^{3}$ & $<0.0010$ & 0.010 & $<0.001$ & NS \\
\hline Chromium & 2.77 & 1.71 & 0.0015 & NS & 0.100 & 0.160 & 0.0069 & NS \\
\hline Copper & 3.38 & 2.07 & 0.015 & NS & 0.190 & 0.320 & 0.076 & NS \\
\hline Lead & 0.69 & 0.43 & $<0.004$ & NS & $<0.010$ & $<0.080$ & $<0.008$ & NS \\
\hline Nickel & 3.98 & 2.38 & 0.03 & NS & 0.210 & 0.310 & 0.031 & NS \\
\hline Silver & 0.43 & 0.24 & $<0.0010$ & NS & 0.0024 & $<0.008$ & 0.016 & NS \\
\hline Zinc & 2.61 & 1.48 & $<0.02$ & NS & 0.0310 & 0.029 & $<0.02$ & NS \\
\hline \multicolumn{9}{|l|}{ Non-Metals } \\
\hline Cyanide & 1.20 & 0.65 & $<0.010$ & NS & $<0.010$ & $<0.003$ & $<0.010$ & NS \\
\hline $\mathrm{pH}$ (unitless) & $6.0--12.5$ & $\mathrm{NA}^{4}$ & 9.60 & NS & NS & 7.40 & 9.07 & NS \\
\hline $\mathrm{TTO}^{5}$ & 2.13 & NA & 0.0018 & 0.0014 & \multicolumn{2}{|c|}{ See Solvent Mgmt. Plan ${ }^{6}$} & \multicolumn{2}{|c|}{ See Solvent Mgmt. Plan } \\
\hline $\begin{array}{ll}1 & \text { All values } \\
2 & <=\text { Preced } \\
3 & \text { NS = Not S } \\
4 & \text { NA = Not } \\
5 & \text { TTO = Tot } \\
6 & \text { TTO monit }\end{array}$ & $\begin{array}{l}\text { those for } \mathrm{pH} \text { ar } \\
\text { rting limits for } \\
\text { d. } \\
\text { able } \\
\text { c Organics (ana } \\
\text { no longer requir }\end{array}$ & $\begin{array}{l}\text { expressed in } \\
\text { dividual par }\end{array}$ & $\begin{array}{l}\text { illigrams } \mathrm{p} \\
\text { eters; that }\end{array}$ & $\begin{array}{l}\text { iter }(\mathrm{mg} / \mathrm{l} \\
\text { not detect }\end{array}$ & equivalent & arts per mi & & \\
\hline
\end{tabular}

\subsubsection{Batch Treatment Plant (Permit No. WB 970401-HX)}

The BTP was permitted to treat effluent from the heat-exchanger descaling operation prior to discharge to the sanitary sewer. It accumulated batches of up to 4,000 gallons, which were then treated to remove metals and adjust pH. The BTP was not operated in 2001. 


\subsubsection{Endangered Species Act}

Based on information provided by the California Department of Fish and Game (DFG) and the US Department of Fish and Wildlife, 14 animal species and 13 plant species occurring in San Mateo County were listed as endangered, threatened, proposed, or of concern. Of these, three of the animal species may occur on or immediately adjacent to the SLAC leaseholding: the California red-legged frog (Rana aurora, subspecies draytonii), the San Francisco garter snake (Thamnophis sirtalis tetrataenia), and the steelhead trout (Oncorhynchus mykiss). All three are aquatic or semi-aquatic species associated with San Francisquito Creek, which is located south of and roughly parallel to the linac. The creek receives run-off from SLAC via three natural drainages, although no part of the creek is on the SLAC leaseholding. SLAC and San Francisquito Creek are shown in Figure 3-3.

The red-legged frog, which was granted threatened status at the federal level in August 1997, is common in and around San Francisquito Creek. However, this frog is truly amphibious and can be found as far as one mile from the nearest water body. Accordingly, it may occur at SLAC, and has figured prominently in the permitting process for erosioncontrol and sediment-control projects in the on-site natural drainages. Stanford University's Center for Conservation Biology (CCB) routinely performs biological surveys throughout Stanford lands; the first such survey was done at SLAC in 1999 and a report was completed in the summer of 2000. These surveys indicate that suitable habitat exists at SLAC for red-legged frogs; however, no verified sightings of red-legged frogs have been recorded to date on the SLAC leaseholding. SLAC and CCB meet periodically to discuss the survey results and update the list of threatened and endangered species for the SLAC leaseholding. This information is routinely incorporated into permit applications for sediment control or erosion control permits.

Historically, the San Francisco garter snake has occurred on and around the SLAC facility. However, this common name encompasses several subspecies, and the subspecies designated as endangered by the federal government ( $T$. s. tetrataenia) interbreeds with a similar subspecies (T. s. infernalis) in southeastern San Mateo County and northwestern Santa Clara County. In other words, the SLAC facility lies near the northeastern edge of the endangered subspecies' distribution, rather than near its center. This distributional limit, coupled with specific habitat requirements, makes the endangered subspecies unlikely to occur at SLAC.

Steelhead populations are increasing in the creek, due in large part to the efforts of the local watershed consortium established under the Coordinated Resource Management and Planning process, of which Stanford University and SLAC are founding members. However, Steelhead are highly unlikely to occur on the SLAC leaseholding, due to the seasonal water flow patterns, the small sizes of the on-site drainages, and downstream drainage modifications by other Stanford University leaseholders. 


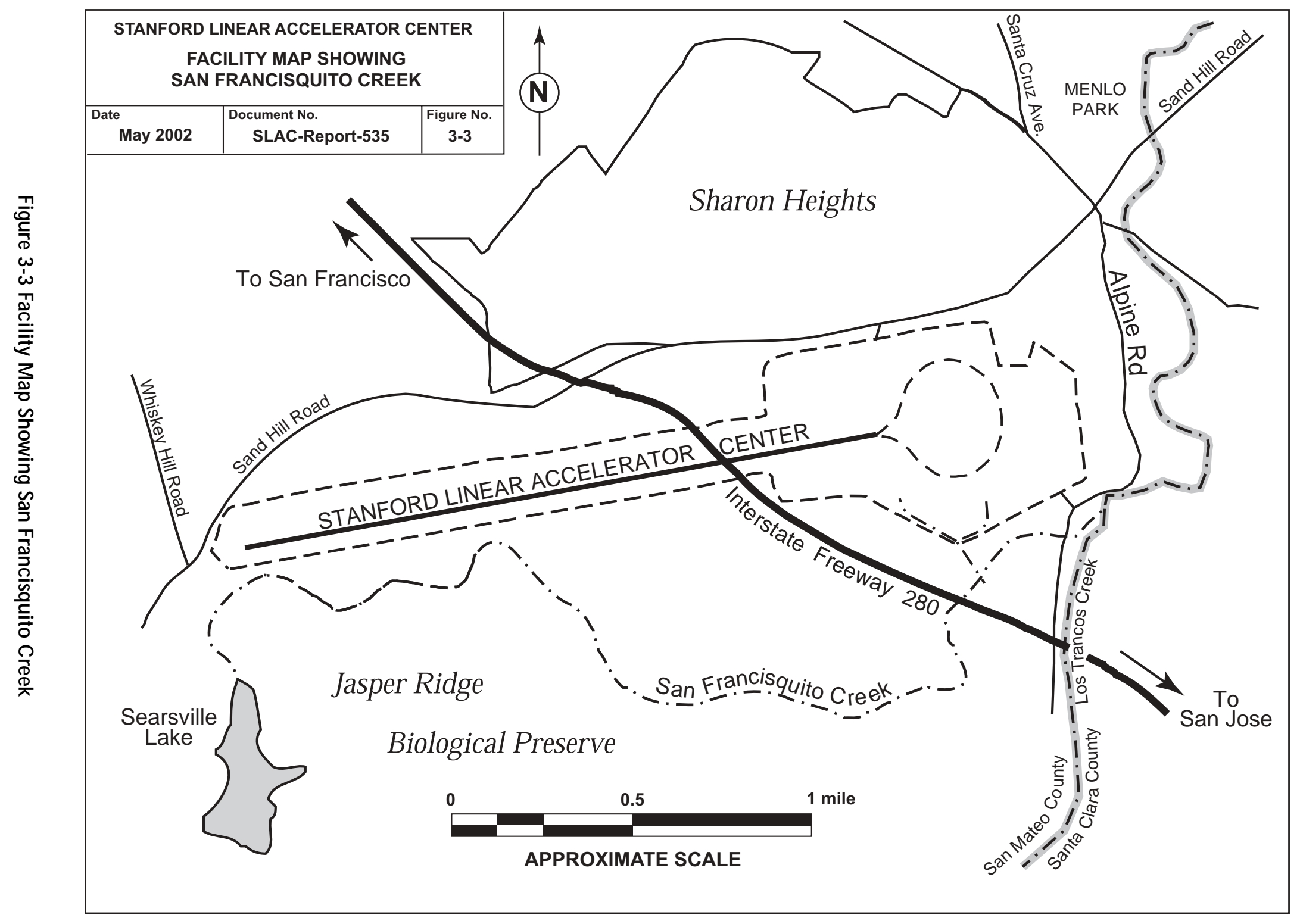




\subsubsection{Federal Insecticide, Fungicide, and Rodenticide Act}

The Federal Insecticide, Fungicide, and Rodenticide Act regulates pesticide use in the U.S. The term "pesticide" refers to insecticides, rodenticides, and herbicides. In 2001, SLAC used licensed subcontractors to apply "registered use" pesticides, while SLAC personnel applied only "general use" pesticides. SLAC continues to use established pesticide and herbicide handling and storage procedures, which were incorporated into the subcontracts for landscape maintenance and pest control and implemented by the subcontractors.

\subsubsection{Executive Order 11990: Protection of Wetlands}

As part of an environmental assessment conducted in 1991, SLAC had a subcontractor perform a survey to determine whether any area(s) within or next to the SLAC facility should be formally designated as wetlands, which are specifically protected under Section 404 of the CWA. The field survey and evaluation were performed using established federal guidance.

According to the survey, the IR- 8 drainage ditch showed characteristics of wetlands, but a definitive evaluation was not possible because of continuing drought conditions and because the study was performed in the fall, when reproductive structures on aquatic vegetation were generally absent.

The portion of the IR-8 drainage channel that represents the majority of the potential wetlands at and around SLAC is approximately 4,000 square feet, less than one-tenth of an acre. By comparison, in practice the US Army Corps of Engineers (COE) uses ten acres as a functional cutoff for "significant" wetlands.

Representatives from the COE, the RWQCB, and the DFG have been on-site to observe erosion-related problems at Sectors 14 and 18. The COE stated that the Sector 18 area appeared to be a wetland, and that the Corps would treat it as such for permitting purposes. Nevertheless, a follow-up to the 1991 survey would be required for a definitive determination. In the meantime, SLAC has operated proactively under the assumption that wetlands exist within and adjacent to the facility boundaries. That is, SLAC applies for various permits to perform erosion control work and characterizes the facility as being associated with wetlands.

\subsubsection{Executive Order 11988: Floodplain Management}

The Federal Emergency Management Agency (FEMA) has developed floodplain maps showing the projected effects of the 100-year storm event. (A more accurate term is a ' $1 \%$ storm event,' because by definition, it has a $1 \%$ probability of occurring in any given year. The term '100-year' inaccurately implies a frequency of one occurrence per century.) The FEMA maps show that a $1 \%$ storm event would be largely confined to the San Francisquito Creek Channel and would not reach the SLAC leaseholding. In a similar vein, SLAC is actively tracking discussions in the Stanford community regarding management options for Searsville Dam, over which water spills into San Francisquito Creek and flows parallel to the linac. The dam may be lowered or removed at some point for habitat restoration.

\subsection{Waste Minimization}

\subsubsection{Site-Wide Program Planning and Development}

SLAC implements its waste minimization program in accordance with established waste minimization plans. The plans address reduction of specific hazardous waste streams in accordance with regulations and provides strategies to increase employee awareness on waste reduction measures for non-hazardous, hazardous and low-level radioactive wastes.

Implementation of waste minimization and pollution prevention is a SLAC line responsibility. Highlights of the SLAC implementation of waste minimization and pollution prevention measures are discussed in Section 3.5.2. 
SLAC has an Environmental Safety Citizens Committee composed of a representative from each division, an ES\&H Coordinator from the Research Division, and the ES\&H Waste Minimization and Pollution Prevention Coordinator. The committee reviews waste streams, identifies pollution prevention opportunities, and reviews new projects.

\subsubsection{Waste Minimization and Pollution Prevention Activities and Implementation}

In 2001, SLAC continued to make progress in implementing waste reduction measures for non-hazardous (municipal) waste, hazardous waste, and low-level radioactive waste. An overview of the program activities and implemented waste reduction measures follows.

\subsubsection{Site-wide Recycling}

A site-wide program for recycling of papers, corrugated cardboard, and beverage cans and bottles has been fully operational for more than ten years.

\subsubsection{Non-hazardous Waste Reduction}

In FY01, SLAC avoided 75 percent disposal of materials to landfill by recycling or diversion measures. The quantities of non-hazardous waste and the materials recycled or diverted from landfills from 1990 to 2001 are summarized in Figure 3-4.

Note: In FY01, 6 tons of redeemable glass, plastic, and aluminum containers were recycled, which does not appear in Figure 3-4.

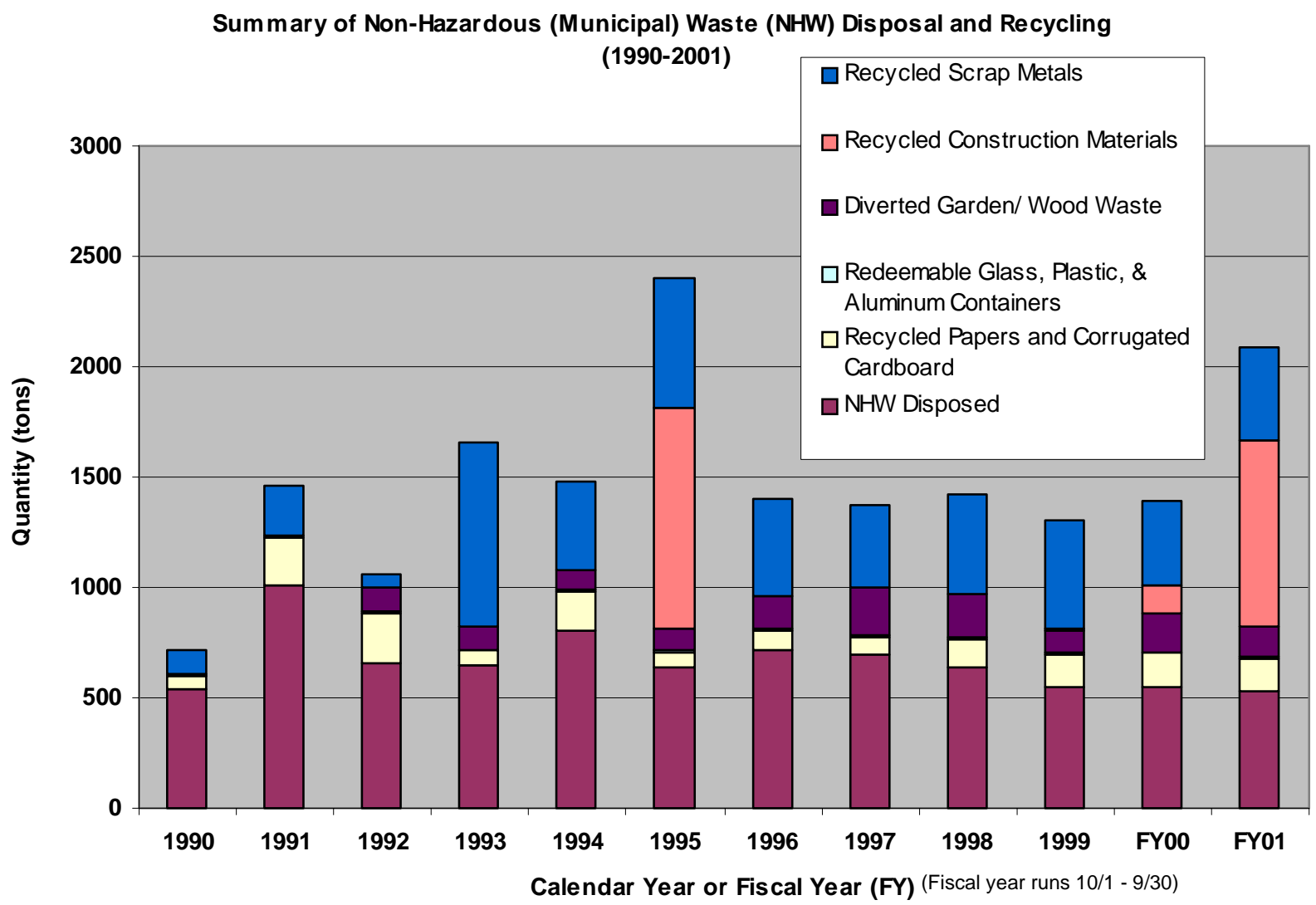

Figure 3-4 Non-Hazardous Waste Summary 


\section{Hazardous Waste Generation for Routine and Non-Routine Operations, TSCA, and} Remediation (1990 - 2001)*

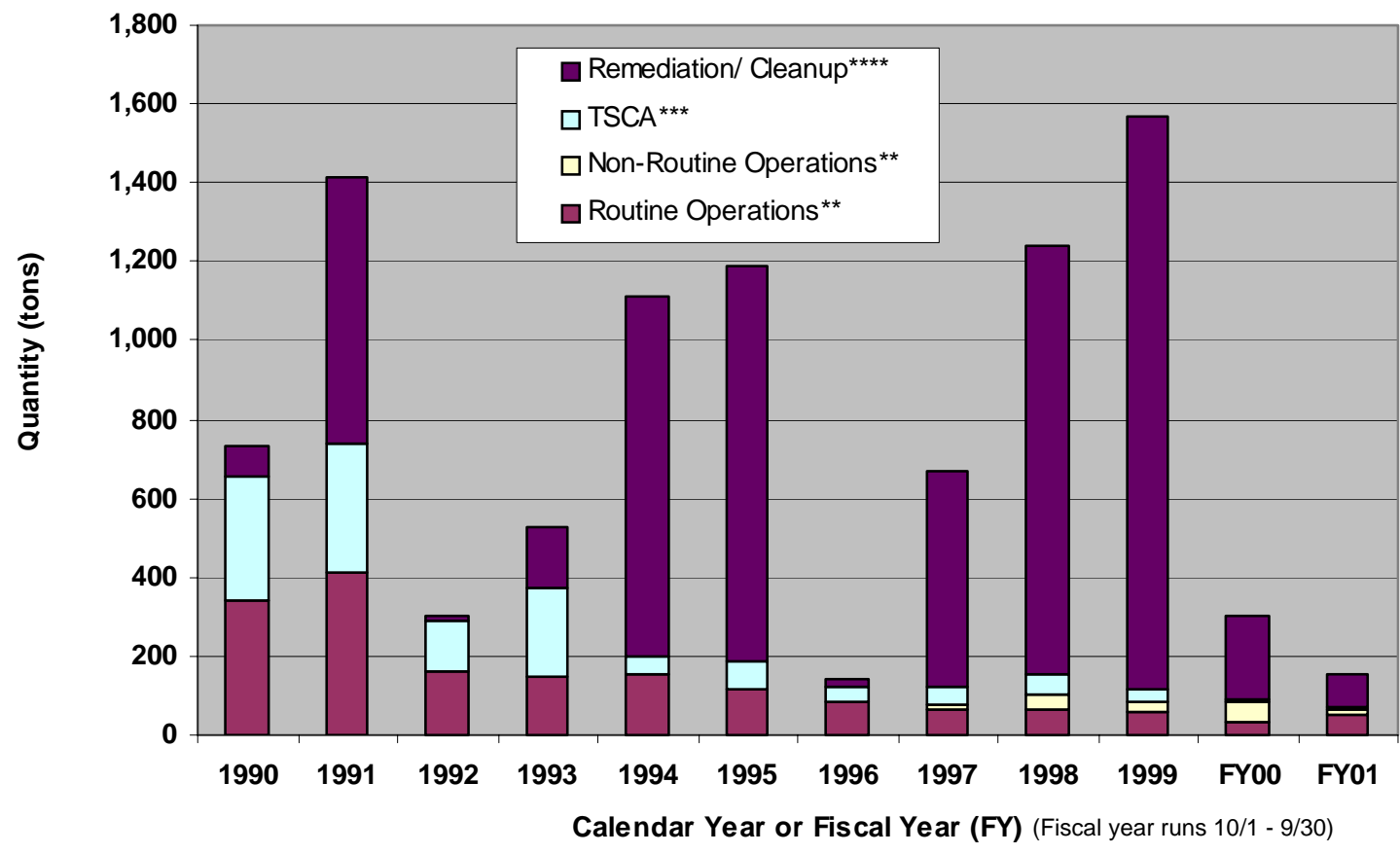

$* * * *$ Remediation wastes were from site restoration, which is usually removal of soils with PCBs, oils, solvents, or metals.

*** TSCA wastes include PCBs from electric equipment replacement and asbestos wastes from building renovations.

** Hazardous waste generated from routine or non-routine operations associated with research projects, supporting operations, and facility maintenance activities. Routine operational hazardous wastes are those from repeated activities.

* Includes hazardous wastes from routine and non-routine operations, TSCA, and remediation.

Non-routine operational hazardous wastes were those from major one-time projects or activities.

\section{Figure 3-5 Hazardous Waste Summary}

\subsubsection{Hazardous Waste Reduction}

Figure 3-5 shows the trends in the generation of hazardous waste for three major categories: operational, Toxic Substances Control Act (TSCA), and remediation-related hazardous waste. As of FY01, SLAC had reduced hazardous waste by $65 \%$ relative to 1993 and by $85 \%$ relative to 1990 .

TSCA wastes result from removal of old electrical (PCB-containing) equipment and construction practices (asbestos-containing materials). The wastes result from phasing-out of these materials from use in SLAC operations. Remediation wastes were the result of past practices or accidental spills.

TSCA and remediation wastes are expected to decrease over time due to elimination of the sources of PCB and asbestos wastes and through cleanup of wastes from past practices and spills. 


\subsubsection{Hazardous Waste}

Hazardous waste has been reduced through a combination of techniques, including:

- Converting empty metal containers and drums to scrap metal.

- Exchanging chemicals with other users.

- Reusing chemicals.

- Returning unused material back to the vendor or manufacturer.

- Sending electrical equipment off site for re-use by other organizations.

- Treating acid and alkaline wastes in accordance with the California Tiered Permit Program.

Due to the above listed activities, hazardous waste was reduced or reused by more than 14 tons during FY01.

\subsubsection{Low-Level Radioactive Waste Reduction}

Although little of the low-level radioactive materials or waste generated at SLAC was routine, SLAC reduced these materials and waste through such measures as segregation and re-use.

The quantities of low-level radioactive wastes were from the accumulation of waste generated over years of operation and various construction and decommissioning activities. Some low-level radioactive waste was generated from maintenance operations. However, generation of this type tends to be sporadic.

\subsection{Waste Management}

\subsubsection{Resource Conservation and Recovery Act}

The Resource Conservation and Recovery Act (RCRA) of 1976 provided "cradle-tograve" authority to regulate hazardous wastes from their generation to their ultimate disposal. This was accomplished through a system of record-keeping, permitting, monitoring, and reporting.

The primary objective of RCRA was to protect human health and the environment. A secondary objective of RCRA, however, was to conserve valuable material and energy resources by promoting beneficial solid waste management, resource recovery, and resource conservation systems.

To meet the second objective, Congress required that the Federal government employ its purchasing power to help create and sustain markets for recycled materials. Under Section 6002 of RCRA, the Federal Government established a program that required Federal purchasing of specified recycled content products. Aspects of this portion of RCRA are discussed in Section 3.6.2, which covers waste prevention, recycling, and federal acquisition.

The different aspects of RCRA as it relates to hazardous waste management activities at SLAC are discussed in Section 3.6.1.1 through Section 3.6.1.4.

\subsubsection{Hazardous Waste Management}

Management of hazardous waste at SLAC was performed by the Hazardous Waste Management Group of the WM Department. SLAC was a generator of hazardous waste and was not permitted to treat hazardous waste or to store it 
for longer than 90 days. The SMC/DHS was the agency responsible for inspecting SLAC as a generator of hazardous waste for compliance with federal, state, and local hazardous waste laws and regulations.

\subsubsection{Hazardous Waste Generation and Tracking}

SLAC utilized a self-developed, site-specific computerized hazardous waste tracking system (WTS). Hazardous waste containers were tracked from the time they are issued to the generator to eventual disposal off-site. The WTS included electronic information fields which generated information for the Biennial, Superfund Amendments and Reauthorization Act (SARA) Title III, and TSCA PCB annual reports.

The majority of hazardous waste generated from operations throughout the site was accumulated in Waste Accumulation Areas (WAAs). Each WAA was managed by a Hazardous Waste and Materials Coordinator, who was trained and provided with written guidelines on proper management of WAAs. Training included spill response preparedness, waste minimization, the SLAC waste-tracking system, and required "refresher" generator training.

SLAC had the potential to generate radioactive hazardous waste. The type of waste generated at SLAC was sometimes referred to as "combined waste" by the state of California, indicating that the waste contained both acceleratorinduced radioactivity and a state or federal hazardous component.

\subsubsection{Hazardous Waste Treatment}

Since 1997, SLAC has operated three hazardous waste treatment units under the State of California Tiered Permit Program (program) using Permit-byRule (PBR) and Conditional Authorization permit tiers. Under this program, SLAC was authorized to treat listed or characteristic hazardous wastes and performed hazardous waste treatment in the RWTP and BTP. The RWTP operated under two PBR permits, one for treatment of acidic and alkaline wastes containing heavy metals from plating and pipe cleaning operations and one for a system to remove water from a heavy metal filter cake generated by the RWTP treatment process. The BTP operated under a Conditional Authorization permit for treatment of aqueous waste containing heavy metals (typically from pipe cleaning operations). The RWTP and BTP units treated non-hazardous rinse waters and wastewaters to meet industrial and sanitary sewer wastewater discharge requirements. The San Mateo County Department of Health Services last inspected these units and the SLAC permit program in December 1999. The units and program were found to be in compliance ("No violations noted").

In August 2001, a new treatment unit was added to the program. The FSUST Groundwater Treatment System at Building 35 was installed to remove volatile and semi-volatile organics that had contaminated ground water when the area contained a leaking underground storage tank. This unit operated under a Conditional Authorization and treated the contaminated ground water to meet industrial and sanitary sewer wastewater discharge requirements.

\subsubsection{Hazardous Waste Generator Inspection}

The SMC/DHS last conducted a Hazardous Waste Generator Inspection during April 2000. The inspection was thorough, with more than 80 locations inspected over three consecutive days. The inspections resulted in no notices 
of violation and SLAC was commended for implementing significant improvements in its waste management practices.

\subsubsection{Waste Prevention, Recycling, and Federal Acquisition}

In earlier years, most of the RCRA Subtitle C Program effort was focused on regulating the management of hazardous waste. The program was expanded on September 14, 1998, when the President signed Executive Order 13101: Greening the Government through Waste Prevention, Recycling, and Federal Acquisition, which required Federal facilities to increase their attention to the purchase of designated products which meet EPA recovered material content requirements.

SLAC reviewed the procurement of designated products in the CPG with the key departments involved with these products. An affirmative procurement program was under development through the Purchasing Department in association with key departments to determine roles and responsibilities and how the departments will implement the program. Progress has been made in 2001 to purchase environmentally friendly janitorial products and vehicular products with recycled content (such as motor oil).

\subsection{Hazardous Material Management}

For a discussion of the TRI reporting requirements under Section 313 of the EPCRA, see Section 3.3.3. The SARA Title III report, and the State equivalent, Hazardous Material Business Plan report, were submitted to SMC/DHS for 2001. See Table 3-8 for report information.

Table 3-8 EPCRA Compliance Information

\begin{tabular}{|l|l|c|c|}
\hline Article & Title & Report Required & Report Submitted \\
\hline \hline $302-303$ & Planning Notification & Yes & Yes \\
\hline 304 & EHS Release Notification & Yes & Yes \\
\hline $311-312$ & MSDS/Chemical Inventory & Yes & Yes \\
\hline 313 & TRI Reporting & Yes & Yes \\
\hline
\end{tabular}

\subsection{Toxic Substances Control Act}

\subsubsection{Polychlorinated Biphenyls (PCBs)}

The Toxic Substances Control Act (TSCA) regulates equipment that is filled with oil or other dielectric fluids containing PCBs. SLAC has some equipment that falls into this category. PCBs, their use, and their disposal are regulated by TSCA. TSCA regulations include provisions for phasing out PCBs and other chemicals that pose a risk to health or the environment. The EPA is responsible for ensuring that facilities are in compliance with TSCA. The State of California further regulates PCBs as a non-RCRA hazardous waste. SLAC programs are designed to comply with these requirements. No EPA inspections regarding TSCA were conducted at SLAC during 2001.

Revision to the Spill Prevention, Controls, and Countermeasures (SPCC) Plan was completed in 2001. The revision updates the above ground tank and transformer inventories, handling and disposal of accumulated rainwater in secondary containments, and creation of an integrated SLAC SPCC map.

\subsubsection{Tank Management}

SLAC completed the installation of an on-site refueling operation. This Gasoline Dispensing Facility (GDF) replaces the mobile refueling service. The GDF consists of one 2000gallon, above-ground, double-walled storage tank with a steel primary tank divided into 
two sections, one for 500 gallons of diesel storage and for 1500 gallons of unleaded gasoline storage. The tank has a gutter leading to a blind sump to collect any spilled fuel.

\subsection{Environmental Quality Acts}

\subsubsection{National Environmental Policy Act}

SLAC formalized a National Environmental Policy Act (NEPA) program in 1992, administered by the Business Services Division (BSD) with EPR providing input and document review. Under this program, proposed project and action descriptions were reviewed to determine if NEPA documentation was required. If so, the proper paperwork would be prepared and submitted. The project or action was entered in a database and tracked. The resulting draft NEPA document was reviewed by specified SLAC staff for concurrence, and was forwarded to the DOE/SSO for review and approval.

NEPA provided a three-level mechanism to ensure that all environmental impacts of and alternatives to performing a proposed project were considered before each project was carried out. The three types of NEPA documentation, in order of increasing complexity, were Categorical Exclusions (CXs), Environmental Assessments, and Environmental Impact Statements.

The aspects that must be considered when scoping and preparing documentation for a proposed project included archaeological sites, wetlands, floodplains, sensitive species, and critical habitats. If any extraordinary circumstances were identified during project scoping, a range of options for the project had to be developed and the impacts of those options had to be evaluated.

In 2001, SLAC submitted six CXs; all were approved by DOE/OAK. These documents addressed a wide range of activities (mostly new construction) involving both primary and backup power supplies, treatment of contaminated groundwater, and various support structures for routine operations.

\subsubsection{California Environmental Quality Act}

The California Department of Fish and Game now has the authority to perform CEQA compliance reviews as it deems necessary for Streambed Alteration Agreement applications. Consequently, SLAC may still be subject to CEQA when applying for permits to perform erosion control projects; however, the California Department of Fish and Game has yet to act on this authority. 


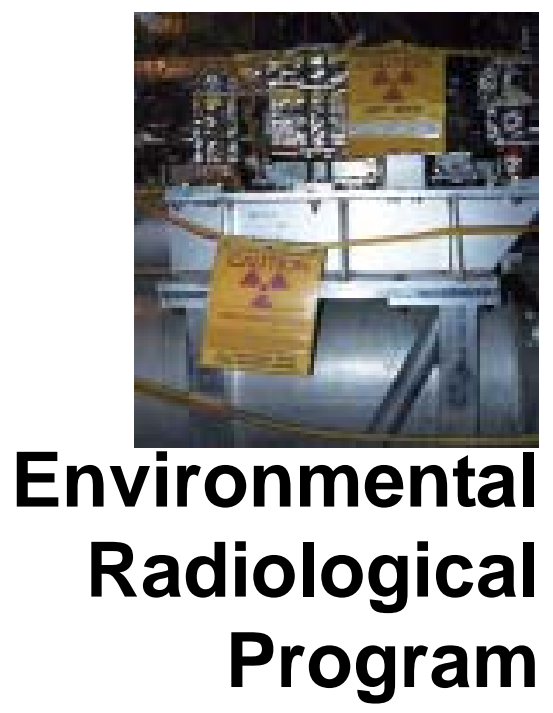

\subsection{Radiation and Radioactivity}

For as long as the earth has been in existence, it and everything on it has been exposed to radiation. Some of this radiation is due to radioactive materials that have existed in the earth's substance and atmosphere from the earth's beginning. (A radioactive material is one that emits radiation in the process of decaying to a stable or non-radioactive form.) Some of the radiation that reaches the earth is produced by the sun and by events occurring deep in space. Radiation originating in space ("cosmic radiation") continually produces radioactive substances on earth and in its atmosphere. As radioactive materials are produced by cosmic radiation, they replace substances that have decayed to stable (non-radioactive) materials. Through this natural process, a relatively constant amount of radioactivity is maintained in the earth's atmosphere and crust.

Given this environment, all plants and animals on earth contain naturally occurring radioactive materials within their bodies. This means that all plants and animals and are constantly exposed to radiation from within themselves. In addition, all plants and animals are exposed to radiation from the radioactive materials in the earth and atmosphere, and to radiation that originates in the sun and in space.

Naturally occurring radiation and radioactivity is responsible for what we call "natural background radiation" or just "natural background." Throughout this chapter, there will be discussions to the quantity of radiation potentially received by a person, an animal, or a plant. The term "dose" will be used to refer to this quantity. (The term "dose" will generally be used in place of the less-familiar, but more precise terms, such as "dose equivalent," "effective dose equivalent," and so on.) Natural background radiation results in a radiation dose to all organisms on earth.

Some human activities add to the radiation dose that plants, animals, and humans receive. For example, mining and building construction bring natural materials that contain radioactivity closer to areas inhabited by plants, animals, and humans; both mining and building construction result in small increases in the radiation dose we all receive. Plane passengers, mountain climbers, and inhabitants of Denver receive more radiation than their sea-level counterparts. This is because there is less atmosphere screening out radiation from the sun and from space. And of course there are many more obvious types of human activities that result in radiation doses to humans: nuclear weapons testing, medical and research uses of radioactive sources and radiation beams (such as Xrays or electrons), nuclear power, and so on.

The remainder of this chapter describes the sources of radiation and radioactivity at SLAC and provides an overview of how SLAC monitors for direct radiation and for radioactivity in water, air, and soil. Section 4.7 summarizes the maximum dose potentially received by a member of the public due 
to SLAC operations in 2001; this maximum dose was a very small fraction of that due to natural background radiation. All potential radiation doses to the public from SLAC operations were also significantly below all regulatory limits.

\subsection{Sources of Radiation and Radioactivity}

The SLAC Linear Accelerator is contained in a tunnel that is encased in concrete and buried 25 feet beneath the ground surface. It is through this underground tunnel that particles are accelerated to nearly the speed of light.

Some particles from the beam strike accelerator components during the acceleration process. When that happens, the decelerating particles may emit secondary radiation in the form of high-energy photons and neutrons. The photon and neutron radiation, emitted during beam loss, is called "direct radiation" throughout this report.

SLAC was designed to meet all the applicable safety and environmental requirements. As planned, nearly all the direct radiation is stopped by the combined shielding of the beam pipe, the accelerator housing, and the earth that surrounds the accelerator tunnel. SLAC monitors the small fraction of the photons and neutrons that pass through the accelerator components, through the surrounding earth, to reach areas outside of the accelerator. This monitoring is described in Section 4.3.

SLAC also assesses, measures, and reports on radioactivity as required by its polices and by state or federal regulations. Section 4.4, Section 4.5, and Section 4.6 describe SLAC programs to assess radioactivity in those materials relevant to possible releases to the environment.

Table 4-1 lists the predominant radionuclides induced in water or air.

Table 4-1 Activation Products in Water or Air

\begin{tabular}{|c|c|c|}
\hline Radionuclide & Half-Life & Primarily Produced in: \\
\hline \hline${ }^{10} \mathrm{C}$ & $19.48 \mathrm{sec}$ & Water \\
\hline${ }^{14} \mathrm{O}$ & $70.91 \mathrm{sec}$ & Water \\
\hline${ }^{15} \mathrm{O}$ & $123 \mathrm{sec}$ & Water or Air \\
\hline${ }^{13} \mathrm{~N}$ & $9.96 \mathrm{~min}$ & Air \\
\hline${ }^{11} \mathrm{C}$ & $20.34 \mathrm{~min}$ & Water or Air \\
\hline${ }^{41} \mathrm{Ar}$ & 1.8 hours & Air \\
\hline${ }^{7} \mathrm{Be}$ & 53.6 days & Water \\
\hline${ }^{3} \mathrm{H}$ & 12.262 years & Water \\
\hline
\end{tabular}

\subsection{Monitoring for Direct Radiation}

DOE standards require SLAC to demonstrate that direct radiation from SLAC in 2001 did not cause any member of the public to receive a radiation dose greater than $100 \mathrm{mrem}$. As described in Section 4.6, even using very conservative assumptions that overestimate dose, in 2001, the maximum dose that could have been received by a member of the public due to direct radiation from SLAC was less than $6 \%$ of the limit.

During 2001, SLAC measured direct radiation at about 30 locations to determine the radiation dose at the boundary of the site. The dosimeters used for this purpose were exchanged and read once each calendar quarter. The dosimeters used for the measurements were supplied and processed by Landauer, Inc. Landauer is accredited by National Voluntary Laboratory Accreditation Program for these dosimeters. 
The exact locations of these measurements and the individual results are reported in Appendix C. The highest net photon dose (with contribution from natural background subtracted) recorded for any of the site boundary locations was a total of $36 \mathrm{mrem}(0.36 \mathrm{mSv})$ for 2001. During the year, no neutron doses were recorded that exceeded the minimum detectable level for the neutron dosimeter.

The SLAC direct radiation measurements at the site boundary were used to calculate the maximum dose that could possibly be received by a member of the public. These measurements were also used to calculate the collective dose to the population that lives within $80 \mathrm{~km}$ of SLAC.

Appendix A gives the details of the calculations used. Please refer to Section 4.7 and Table 4-3 for a summary of the results and information on how they compare to natural background radiation.

As described in Section 4.7, the maximum direct radiation dose that could possibly have been received by a member of the public due to SLAC operations in 2001 was very small compared to natural background radiation and to all regulatory limits.

\subsection{Assessment of Airborne Radioactivity}

Environmental Protection Agency (EPA) regulations (40 CFR 61) enacted under the Clean Air Act and DOE Order 5400.5 require SLAC to demonstrate that airborne radioactivity released in 2001 did not cause any member of the public to receive a dose greater than $10 \mathrm{mrem}$. As described in Section 4.7, even using very conservative assumptions that overestimate dose, in 2001, the maximum dose that could have been received by a member of the public due to airborne radioactivity from SLAC was less than $1 \%$ of the Clean Air Act limit.

Supporting the conclusions on the maximum dose that could have resulted from airborne emissions, DOE requires SLAC to prepare an annual report that satisfies EPA specifications. The report describes possible sources, types, and quantities of airborne radioactivity released to the atmosphere. In addition to information on the maximum individual dose, the report must also assess the collective dose to the population that lives within $80 \mathrm{~km}$ of SLAC. Appendix B is a copy of this report.

Please refer to Section 4.7 and Table 4-3 for a summary of the results and information on how they compare to natural background radiation.

\subsection{Assessment of Radioactivity in Water}

Three types of water are monitored for radioactivity at SLAC, industrial wastewater, storm water, and groundwater. This section will summarize the monitoring and results for each type.

\subsubsection{Industrial Wastewater}

Federal and state regulations (10 CFR 20.2003 and 17 CCR 30253) limit the radioactivity in industrial wastewater that SLAC releases to the sanitary sewer. In 2001, SLAC releases totaled about $0.04 \%$ of the limit. The paragraphs below provide information on industrial wastewater and its radiological monitoring at SLAC.

Nearly all of the SLAC wastewater results from activities that do not have the potential to produce radioactivity in the water and that also do not bring water in contact with any radioactive material. However, a small fraction of SLAC wastewater is the result of activities that could cause water to contain trace amounts of radioactivity.

Monitoring and results: In 2001, SLAC sampled and analyzed wastewater at about 20 discharge points. No radioactivity above background was found in any of the samples except tritium $\left({ }^{3} \mathrm{H}\right)$. Table 4-2 summarizes the results of wastewater monitoring for 1992 through 2001. Only ${ }^{3} \mathrm{H}$ was detected over this period of years. The final column of the table compares the radioactivity discharged by SLAC into the sanitary sewer with the 
annual limit for such discharges set by federal and state regulations. During 2001, SLAC discharges into the sanitary sewer amounted to only $0.04 \%$ of the permitted annual limit.

Table 4-2 Radioactivity in SLAC Wastewater

\begin{tabular}{c|c|c|c}
\hline Year & Radionuclide & $\begin{array}{c}\text { Activity } \\
\text { (mCi) }\end{array}$ & $\begin{array}{c}\text { Percentage } \\
\text { of Annual } \\
\text { Limit }\end{array}$ \\
\hline 1992 & ${ }^{3} \mathrm{H}$ & 40.6 & $0.8 \%$ \\
\hline 1993 & ${ }^{3} \mathrm{H}$ & 2.5 & $0.05 \%$ \\
\hline 1994 & ${ }^{3} \mathrm{H}$ & 1.7 & $0.03 \%$ \\
\hline 1995 & ${ }^{3} \mathrm{H}$ & 10.8 & $0.2 \%$ \\
\hline 1996 & ${ }^{3} \mathrm{H}$ & 338.8 & $6.8 \%$ \\
\hline 1997 & ${ }^{3} \mathrm{H}$ & 22.3 & $0.5 \%$ \\
\hline 1998 & ${ }^{3} \mathrm{H}$ & 71.8 & $1.4 \%$ \\
\hline 1999 & ${ }^{3} \mathrm{H}$ & 7.1 & $0.1 \%$ \\
\hline 2000 & ${ }^{3} \mathrm{H}$ & 2.4 & $0.05 \%$ \\
\hline 2001 & ${ }^{3} \mathrm{H}$ & 2.1 & $0.04 \%$ \\
\hline
\end{tabular}

Reporting: In 2001, SLAC reported the results of wastewater monitoring to the South Bayside System Authority (SBSA) at the end of each calendar quarter.

\subsubsection{Storm Water}

In 2001 (and in all previous years), no radioactivity above background levels was found in any storm water sample. The paragraphs below provide information on storm water and its radiological monitoring at SLAC.

Monitoring and results: The program for monitoring storm water is described in Section 3.4.2 of this report. In 2001 (as in previous years), no radioactivity above background levels was found in any storm water sample.

Reporting: In 2001, SLAC reported the results of storm water monitoring (including checks for radioactivity) to the Regional Water Quality Control Board.

\subsubsection{Groundwater}

Monitoring and results: The program for groundwater is described in Chapter 5 of this report. Throughout 2001, all groundwater samples were below the federal and state limits set for radioactivity.

\subsection{Assessment of Radioactivity in Soil}

Throughout 2001, no soil samples were found to contain radioactivity above background levels of naturally-occurring radioactivity. The paragraphs below provide information on soil and its radiological monitoring at SLAC.

Monitoring and results: Throughout 2001, SLAC sampled and analyzed soil for projects involving excavation on the SLAC site. During the year, no samples were found to contain radioactivity above background level. 


\subsection{Summary: Potential Dose to the Public}

The maximum possible doses to members of the public due to SLAC are small compared to dose from natural background radiation and all regulatory limits.

Table 4-3 summarizes the dose results for the two modes that were the largest contributors in 2001; direct radiation and airborne radioactivity. In this table the reported maximum dose is based on a person being present 24 hours per day at the location of one of the buildings on the northern side of Sand Hill Road about $0.3 \mathrm{~km}$ east of where the main entrance road to SLAC intersects with San Hill Road. Table 4-3 also compares the 2001 findings with applicable limits and natural background.

Table 4-3 Summary of Annual Dose due to SLAC Operations in 2001

\begin{tabular}{c|c|c|c|c}
\hline & $\begin{array}{c}\text { Maximum Dose } \\
\text { to General } \\
\text { Public; direct } \\
\text { radiation only }\end{array}$ & $\begin{array}{c}\text { Maximum Dose to } \\
\text { General Public; } \\
\text { from airborne } \\
\text { radioactivity only }\end{array}$ & $\begin{array}{c}\text { Maximum Dose to } \\
\text { General Public; } \\
\text { airborne + direct }\end{array}$ & $\begin{array}{c}\text { Collective Dose } \\
\text { to Population } \\
\text { within 80 km of } \\
\text { SLAC }\end{array}$ \\
\hline Dose from SLAC in 2001 & $5.2 \mathrm{mrem}$ & $0.08 \mathrm{mrem}$ & $5.3 \mathrm{mrem}$ & $\begin{array}{c}20.6 \text { (direct) } \\
+0.23 \text { (air) } \\
21 \text { person-rem }\end{array}$ \\
\hline $\begin{array}{c}\text { DOE Radiation } \\
\text { Protection Standard }\end{array}$ & $100 \mathrm{mrem}$ & $10 \mathrm{mrem}$ & $100 \mathrm{mrem}$ & $\mathrm{n} / \mathrm{a}$ \\
\hline $\begin{array}{c}\text { SLAC 2001 Max. Dose as } \\
\text { Percentage of DOE } \\
\text { Standard }\end{array}$ & $5 \%$ & $0.8 \%$ & $5 \%$ & $\mathrm{n} / \mathrm{a}$ \\
\hline $\begin{array}{c}\text { Dose from Natural } \\
\text { Background }\end{array}$ & $100 \mathrm{mrem}$ & $200 \mathrm{mrem}$ & $300 \mathrm{mrem}$ & $1,475,233$ \\
person-rem
\end{tabular}

Table 4-4 1995-2001 Summary of Calculated Dose to Maximally Exposed Individual (MEI) from Operations at SLAC

\begin{tabular}{|c||c|c|}
\hline Year & $\begin{array}{c}\text { Dose to MEI from SLAC Direct \& } \\
\text { Airborne Radiation (mrem) }\end{array}$ & $\begin{array}{c}\text { Average Dose due to Total } \\
\text { Natural Background } \\
\text { Radiation (mrem) }\end{array}$ \\
\hline \hline 1995 & 2.2 & 300 \\
\hline 1996 & 4.6 & 300 \\
\hline 1997 & 4.2 & 300 \\
\hline 1998 & 4.6 & 300 \\
\hline 1999 & 4.5 & 300 \\
\hline 2000 & 5.7 & 300 \\
\hline 2001 & 5.3 & 300 \\
\hline 1995 & 2.2 & 300 \\
\hline
\end{tabular}


Figure 4-1 presents the maximum dose potentially received by a member of the public from direct radiation and airborne radioactivity due to SLAC operations in 1995 through 2001 and compares it to the average dose due to natural background radiation and radioactivity. Figure 4-1 is based on the data in Table 4-4.

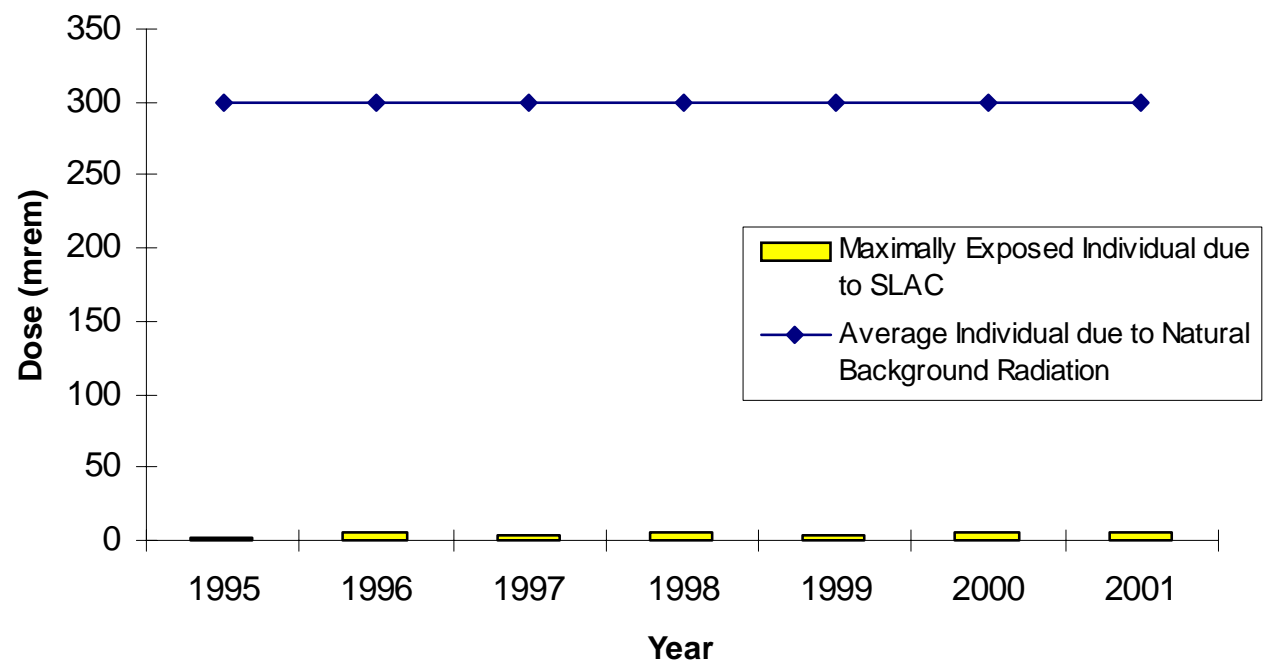

Figure 4-1: Annual Total Dose from SLAC and from Natural Background

As shown by the above tables and graph, the maximum dose potentially received by a member of the public due to SLAC operations in 2001 was a very small fraction of that due to natural background radiation. All potential radiation doses to the public from SLAC operations were also significantly below all regulatory limits.

\subsection{Biota Dose}

DOE Order 5400.5 includes an interim dose limit for aquatic animals [DOE 5400.5, Chapter II, Section 3.a.(5)] of $1 \mathrm{rad} /$ day from radioactive material in liquid wastes discharged to natural waterways. In July 2002, DOE issued a technical standard titled “A Graded Approach for Evaluating Radiation Doses to Aquatic and Terrestrial Biota." The standard suggests that DOE facilities protect plants and animals by assuring that the following doses rates, due to "...exposure to radiation or radioactive material releases" into the applicable environment are not exceeded:

- Aquatic animals: should not exceed $1 \mathrm{rad} /$ day (per previous DOE 5400.5 citation)

- Terrestrial plants: should not exceed $1 \mathrm{rad} /$ day

- Terrestrial animals: should not exceed $0.1 \mathrm{rad} / \mathrm{day}$

The standard includes information about its intended applicability. For example, it makes clear that its dose rate guidelines are intended for populations of plants and animals, rather than for individual organisms (see Module 1, Section 3). The standard also makes it clear that facilities are not expected to evaluate certain types of radiation exposure to biota, including:

- Exposure to direct radiation from experimental facilities such as particle beam accelerators (see Module 1, Section 3.3; also note the exposure routes specified for consideration in Module 2, Section 1.2)

- Airborne emissions of radionuclides (see Module 2, Section 1.2.1) 
In 2001, SLAC tested soil and water samples for the presence of radioactivity in excess of natural background as detailed in this chapter.

${ }^{3} \mathrm{H}$ occasionally was found in industrial wastewater in 2001 (see Section 4.5.1 for description of sources and monitoring). Animal populations have no opportunity for access to industrial wastewater at SLAC.

No groundwater was found with ${ }^{3} \mathrm{H}$ concentrations in excess of the drinking water standards set by state and federal regulations (see Section 4.5.3 for details of groundwater monitoring; refer to under 22 CCR $\$ 64443$ and 40 CFR $\$ 141.66$ for the drinking water standards.)

There is no possibility that activities at SLAC will result in dose rates that approach or exceed the guidelines of the standard.

\subsection{Low-Level Radioactive Waste Management}

SLAC continues to manage low-level radioactive waste (LLRW) safely and responsibly. All newly generated wastes are managed or processed and shipped to final disposal facilities.

Two types of LLRW are typically generated at SLAC, scrap metal and routine LLRW. Facility and maintenance upgrades differ from year to year, the volume of scrap metal waste generated each year can vary widely and is difficult to predict.

The generation of routine LLRW is low in volume and stable in amount. This outcome reflects effective SLAC efforts to train and educate personnel on ways to minimize generating LLRW. Increased awareness, and a commitment to minimize wastes all contributed to the low volume of LLRW 


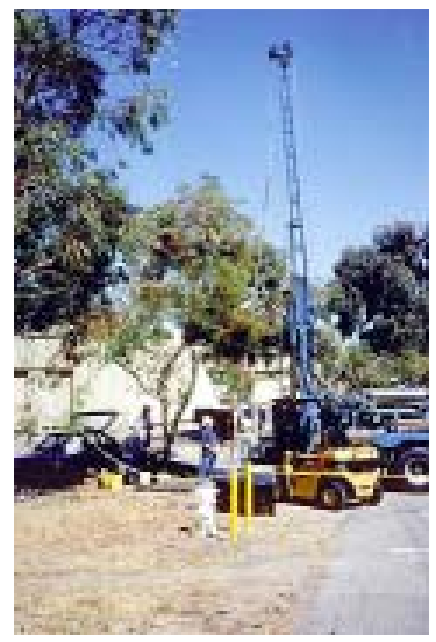

\section{Groundwater Protection and Restoration}

\subsection{Introduction}

SLAC is an academic unit of Stanford University located on land that is part of the Stanford academic preserve. It is intended that the land be maintained in a way to ensure future unrestricted uses. To accomplish this, the groundwater protection and restoration programs at SLAC provide processes for evaluating soil and groundwater with the goal of protecting human health and the environment now and into the future.

Environmental concerns at SLAC are limited in number, small in scale, and actively being managed or eliminated.

\subsection{Documentation}

The groundwater regime at the SLAC facility and nearby off-site areas has been comprehensively documented in the SLAC Hydrogeologic Review completed in 1994. This report compiled data and summarized results of the numerous geologic, hydrogeologic, and hydrogeochemical investigations that had taken place at or near SLAC for the following reasons:

- Water resources studies

- Research

- Geotechnical studies (used to site the structures being built at SLAC)

- Environmental monitoring purposes

The report developed a conceptual model of the groundwater regime at SLAC. Based on many tests in exploratory borings and wells, the hydraulic conductivity of this bedrock is much less than the range of hydraulic conductivity generally accepted as representing natural aquifer material. In other words, the groundwater at SLAC is not suitable as a drinking water source due to low flow as well as high salt content. 
In 2001, a report was submitted to the California Regional Water Quality Control Board (RWQCB) that contained information to formally request exemption for groundwater at SLAC as a potential municipal or domestic supply source based on criteria specified in state and RWQCB Resolutions, Numbers 88-63 and 89-39, respectively.

\subsection{Identification and Summary of Areas with Potential Chemical Impact}

The SLAC 1994 report entitled Summary and Identification of Potentially Contaminated Sites provided a summary of areas that might be impacted by hazardous substances. Information for the report was collected from a variety of sources including incident reports, aerial photographs, operations records, reports on previous investigations, and interviews with SLAC personnel throughout the facility. As other potentially impacted areas were identified, they were incorporated into a master list. These sites were evaluated and the need for further investigation was prioritized. Several areas were evaluated in 2001.

\subsection{Strategies for Controlling Potential Sources of Chemicals}

Strategies for chemical source control involved measures to control known soil or groundwater impacts, and procedures to avoid practices that could affect soil and groundwater contamination. In addition, the Storm Water Pollution Prevention Plan (SWPPP) and the Spill Prevention, Control, and Countermeasure Plan (SPCC) discuss best management practices for preventing adverse impacts from spills at the SLAC facility. Environment, Safety, and Health Manual Chapter 21, "Secondary Containment of Hazardous Material and Waste" and Chapter 32, "PCB and Oil-filled Equipment" address practices for preventing these substances from reaching soil or groundwater.

\subsection{Restoration Activities}

SLAC first began to develop a comprehensive Environmental Restoration Program (ERP) in 1991. The program addresses discovery and characterization through remediation and long-term monitoring or maintenance where required. The restoration approach at SLAC is as follows:

1. Identify sites with actual or potential impacts (involving soil, groundwater, surface water, and/or air)

2. Prioritize impacted sites based on site complexity, nature of chemical impact, associated risks, remaining data needs, and projected remedy

3. Perform investigations and identify remedies protective of human health and the environment, beginning with the highest-priority sites

In 2001, SLAC was generally at step 3 (of the steps listed above). Investigative work proceeded this year for impacted groundwater sites that are discussed in this section.

SLAC followed the general Comprehensive Environmental Response, Compensation, and Liability Act (CERCLA) technical guidance in investigating and remediating soil and groundwater. SLAC was not listed in the National Priorities List as a Superfund site because EPA determined that the conditions at the site did not warrant inclusion on the National Priorities List. The RWQCB provided oversight and approval of restoration activities that impacted surface or groundwater at SLAC. The San Mateo Department of Health Services (SMC/DHS) conducted oversight of environmental restoration activities involving remediation of chemically impacted soil.

SLAC ERP personnel continued investigations for site characterization and evaluation of remedial alternatives. Four groundwater sites have been identified and are monitored (see Figure 5-2 on page 75 and Figure 5-3 on page 76). One of these sites is monitored on a semi-annual basis under RWQCB Waste Discharge Order No. 85-88. 
Investigation and remediation of three sites continued in 2001; the 505 and 512 transformer substations and 1.0/1.5 Megawatt Power Supply (MWPS). A report documenting the activities was submitted to the EPA, the RWQCB, and the SMC/DHS. 


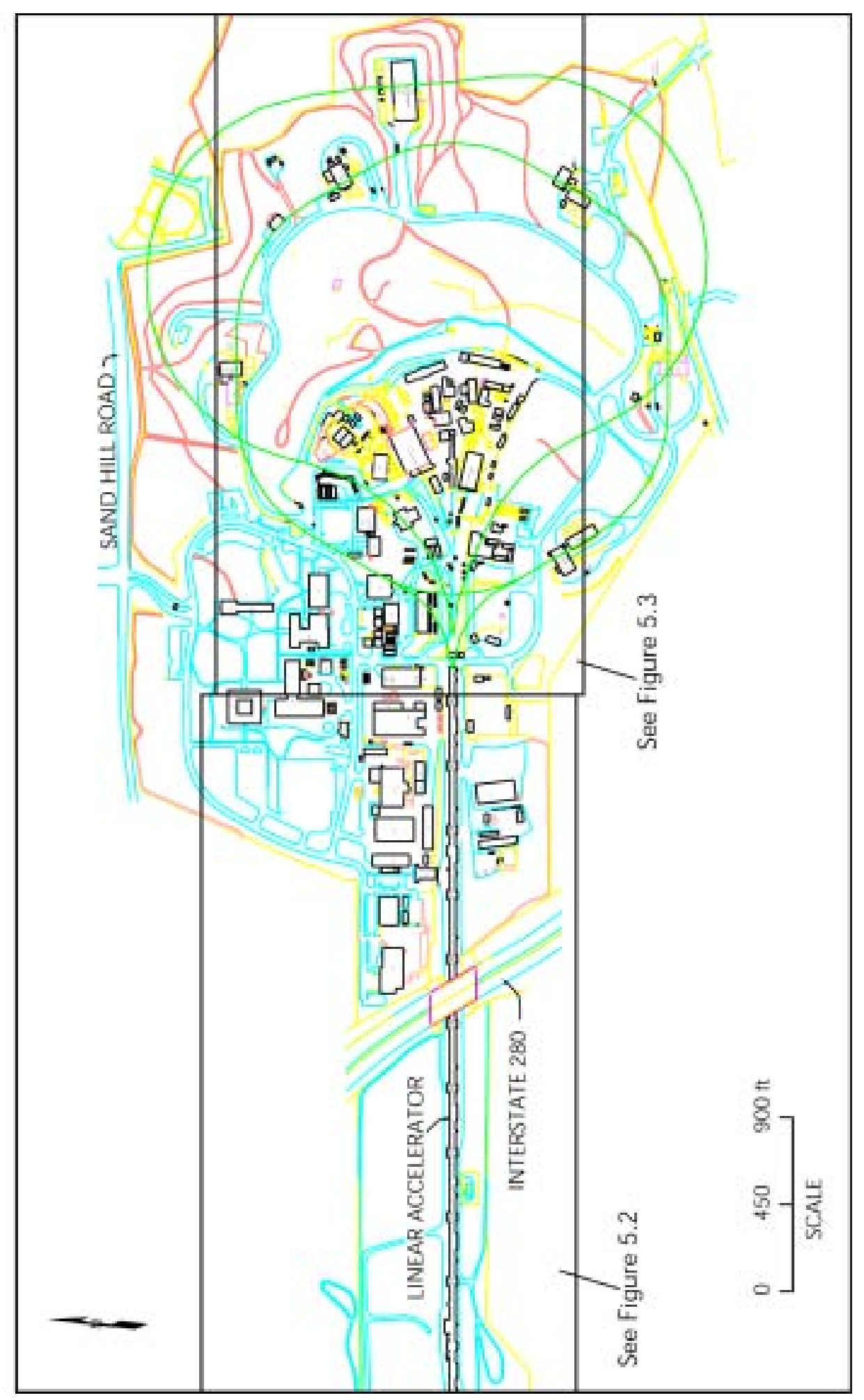

Figure 5-1 Site Map 


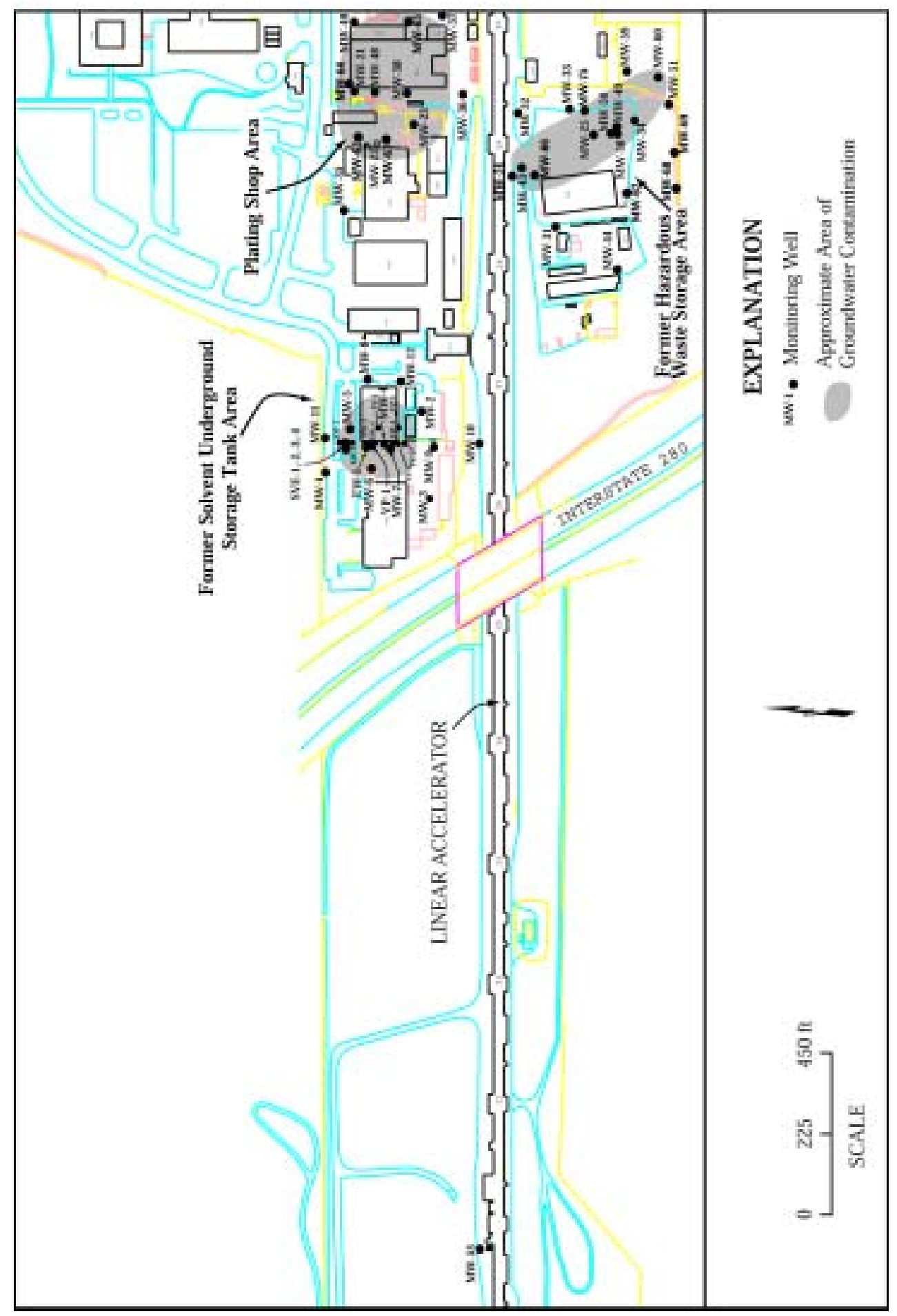

Figure 5-2 Location of Western G roundwater Monitoring Well Network and Areas with Groundwater Contamination 


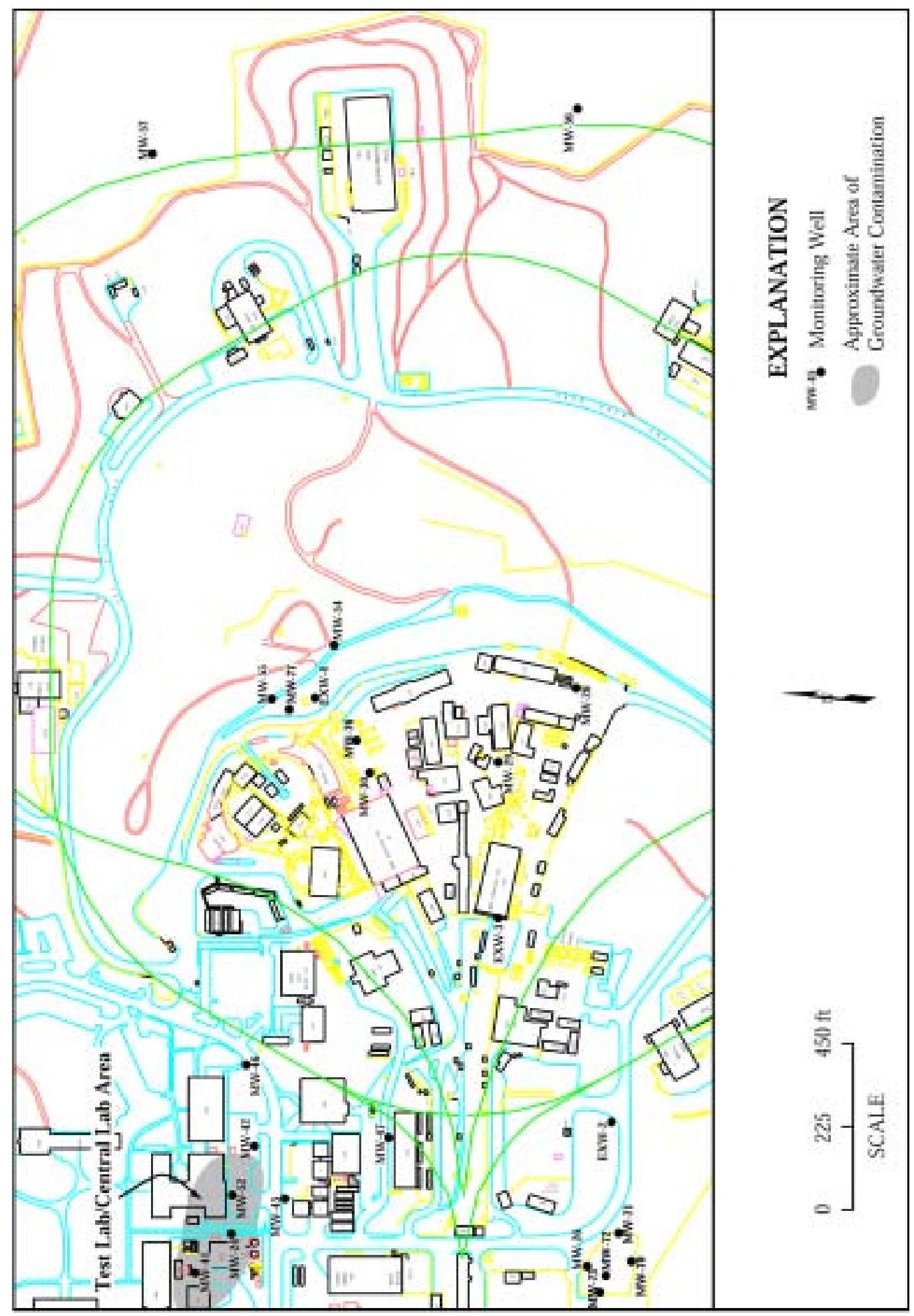

Figure 5-3 Location of Eastern G roundwater Monitoring Well N etwork and Areas with Groundwater Contamination 


\subsection{Groundwater Characterization Monitoring Network}

\subsubsection{Summary of 2001 Results and Issues}

Work continued in 2001 on installing additional wells to define the lateral and vertical groundwater condition.

Groundwater samples were collected at least once from 79 wells in 2001 and analyzed for a variety of constituents. Figure 5-1 on page 74 shows the portion of the site that contains the monitoring network. Figure 5-2 on page 75 and Figure 53 on page 76 show the specific well locations. The groundwater analytical results were generally within each well's historic range of concentrations.

\subsubsection{Background}

The groundwater monitoring network included 15 wells that provided environmental surveillance of groundwater conditions. They were used to monitor general groundwater quality in the major areas of the facility that historically or presently store, handle, or use chemicals. In addition, the groundwater monitoring network at SLAC included 55 wells that checked groundwater at four small sites that merit attention.

During ongoing remedial investigations, selected wells were sampled and analyzed on a semi-annual basis. Samples could have been analyzed for one or more of the following:

- VOCs and Semi-Volatile Organic Compounds

- Total Petroleum Hydrocarbons (TPHs)

- Metals

- Polychlorinated Biphenyls (PCBS)

- Total Dissolved Solids (TDS)

- General minerals

- Tritium

Only VOCs required additional investigation. The results of semi-annual sampling and analysis of wells were reported to the RWQCB in semi-annual monitoring reports.

Table 5-1 summarizes the wells at SLAC by the number of wells, area of the facility, and the purpose of the well. The purpose of each well could be either monitoring chemicals of interest or environmental surveillance, including general background monitoring. In addition, four new monitoring wells and five extraction wells were installed at the Former Solvent Underground Storage Tank area (FSUST) as part of a groundwater extraction system. As noted in Table 5-1, the four areas that merit further attention include:

- The Former Hazardous Waste Storage Area (FHWSA)

- The Former Solvent Underground Storage Tank (FSUST)

- The Test Lab and Central Lab areas

- The area of the Plating Shop 
Table 5-1 Purpose and Location of Monitoring Wells

\begin{tabular}{|l|c|c|}
\hline \multicolumn{2}{|l|}{ Number of Active Wells } \\
\hline Area of Site & $\begin{array}{c}\text { Monitoring Plumes with } \\
\text { Chemicals of Interest }\end{array}$ & Environmental Surveillance \\
\hline \hline FSUST $^{\text {a }}$ & 18 wells & \\
\hline FHWSA $^{\text {bH }}$ & 16 wells & \\
\hline Test Lab/Central Lab & 7 wells & 4 wells \\
\hline Plating Shop & 12 wells & 5 wells \\
\hline Research Yard & & 1 wells \\
\hline Beam Dump East & & 1 well \\
\hline $\begin{array}{l}\text { Master Substation; } \\
\text { Lower Salvage Yard }\end{array}$ & & 1 well \\
\hline CWMA & & 5 wells \\
\hline End Station B & & \\
\hline Vacuum Assembly Building & & \\
\hline Other (remote area) & & \\
\hline
\end{tabular}

a Former Solvent Underground Storage Tank

b Former Hazardous Waste Storage Area

c Centralized Waste Management Area

The locations with chemicals of interest in groundwater are shown in Figure 5-2 on page 75 and in Figure 5-3 on page 76.

The organic chemicals most commonly found in groundwater at SLAC are trichloroethene (TCE) and its breakdown products. TCE is historically used at SLAC as a cleaning solvent. TCE was no longer in general use at SLAC, although it is used in very small quantities in a few research laboratories. The four groundwater sites warranting further attention are discussed in detail in the next section. This is followed by a discussion of PCB impacted soil sites.

\subsection{Groundwater Site Descriptions and Results}

\subsubsection{Former Solvent Underground Storage Tank}

\subsubsection{Background}

A groundwater monitoring network was located in proximity to the SLAC Plant Maintenance building in the northwestern portion of the facility (see Figure 5-2 on page 75). This network consisted of eighteen wells which were being used to monitor the migration of chemical constituents associated with the Former Solvent Underground Storage Tank (FSUST). The FSUST was used to store organic solvents during the period of 1967 to 1978. A pressure test performed on the FSUST in 1983 indicated a leak. The FSUST and accessible chemically impacted soil were removed in December 1983. 
The RWQCB required that SLAC monitor selected wells at the FSUST site on a semi-annual basis (RWQCB Waste Discharge Order 85-88). Since 1987, the samples have been analyzed for VOCs (Environmental Protection Agency Methods 8010/8020) by an analytical laboratory certified by the California Department of Health Services.

\subsubsection{2001 Results and Issues}

The results of investigations performed at the FSUST were provided in two draft reports, the Site Characterization for the Former Solvent Underground Storage Tank Area, and the Evaluation of Remedial Alternatives for the Former Solvent Underground Storage Tank Area.

The Site Characterization report described the nature and extent of chemicals in the soil and groundwater at this site and evaluated potential risks posed by these chemicals. The evaluation of the potential risks was used to identify remedial goals.

The Evaluation of Remedial Alternatives report established remedial action objectives and then evaluated 42 alternatives to determine which would meet best the objectives. Comments were received from the California RWQCB. The final reports are expected to be completed in 2002.

The selected alternative, a groundwater extraction and treatment system, was constructed at the FSUST area during the summer of 2001. The system was constructed for testing the effectiveness of a 5well extraction system for achieving hydraulic control of a small area of chemically-impacted groundwater at the FSUST area. Chemicals of interest in groundwater at the FSUST area include volatile organic compounds (VOCs) and semi-volatile organic compounds (SVOCs). The extraction system has been in operation since August 27, 2001.

During the dry season months, the total flow rate for the 5-well extraction system stabilized at 0.13 gallons per minute (gpm) and increased to $0.23 \mathrm{gpm}$ with the onset of the wet season. As of December 31, 2001, approximately 33,000 gallons of groundwater has been treated using granular activated carbon and approximately 45 pounds of VOCs and SVOCs removed.

\subsubsection{Former Hazardous Waste Storage Area}

\subsubsection{Background}

The Former Hazardous Waste Storage Area (FHWSA) was in use from approximately 1965 to 1982. During closure of the FHWSA, PCBS were found in shallow soils. As a result, several inches of topsoil were removed. Monitoring well 25 (MW-25) was installed in this area in 1990, and VOCs were detected in the groundwater.

Eighteen wells and more than fifty soil borings have been installed at this site. Figure 5-2 on page 75 defines the limited extent of VOCs in the groundwater.

Most of the impacted groundwater appeared to be confined to the Santa Clara Formation which comprised about the upper 20 feet of bedrock. 


\subsubsection{2001 Results and Issues}

Two areas with soil and groundwater impacted with chemicals of interest have been delineated at the site.

Two additional wells installed in 2001 delineated the extent of groundwater impacted with the chemicals of interest at the east and north ends of the site. In addition, a fate and transport study and a risk assessment were performed during 2001 for the chemicals of interest that were present in groundwater and soil at the site. Characterization studies will continue in 2002.

\subsubsection{Plating Shop}

\subsubsection{Background}

In 1990, three monitoring wells, MW-21, MW-22, and MW-23, were installed downgradient of the Plating Shop. Constituents of interest were detected in all three wells and an investigation began as described below.

A concrete steam cleaning pad was located adjacent to the Plating Shop and work performed in 1997 identified the soil beneath it as a potential source of VOCs in the groundwater. Consequently, an Interim Removal Action was performed in 1998, which included removing the pad, and excavating approximately 200 cubic yards of chemically impacted soil for off-site disposal. A new steam cleaning pad was built to replace it at a location to the south of the original pad. In order to construct it at the new location, well MW-22 had to be destroyed.

Four new wells were installed in 2000, and additional soil samples were collected as part of the source investigation. Figure 5-2 on page 75 illustrates the limited extent of VOCs in groundwater.

\subsubsection{2001 Results and Issues}

Data analyses and plans for further characterization activities were completed in 2001. Characterization studies will continue in 2002.

\subsubsection{Test Lab and Central Lab}

\subsubsection{Background}

Monitoring Well 24 was installed between the Test Lab and Central Lab in 1990 at the site of a former leaking diesel pump. Chemically impacted soil was removed and the well was installed to monitor for the possible presence of diesel fuel, which has never been detected in this well. Chlorinated solvents have been detected.

A soil gas survey and soil borings were drilled over the entire Test $\mathrm{Lab}$ and Central Lab area to delineate the sources of contamination. Results of the investigation indicated three possible source areas for VOCs, including one adjacent to the Test Laboratory and two adjacent to the Central Laboratory. 


\subsubsection{2001 Results and Issues}

Results of the investigative work at the Test Lab/ Central Lab area were detailed in the site characterization report for the Test Lab/ Central Lab area. The report was submitted to the RWQCB for review and comment in late 1999. Comments from the regulators were received in 2000. Response to comments was completed in 2001 along with further characterization. The report will be revised in 2002.

Based on the characterization studies and risk assessments indicating no potential risks to human health and the environment, the revised report was to propose long term monitoring of the plume. The final report was expected to be completed in 2002.

\subsection{Soil Site Description and Results}

\subsubsection{Lower Salvage Yard}

\subsubsection{Background}

The Lower Salvage Yard historically has been used for storage of salvaged equipment, including oil-filled equipment and other materials, such as scrap metal including lead. Prior to its use as a salvage yard, the first SLAC substation occupied the area.

Site characterization data indicated several chemicals of interest including PCBs and petroleum hydrocarbons. Thus a removal action was initiated in 1999.

A total of 3,114 tons of material were excavated from the Lower Salvage Yard to achieve the cleanup goal of 1 part per million PCBs. However, PCBs above the cleanup goal remained in the side walls of the excavation. Thus, additional excavation will be required in the future. In addition, PCBs were detected in a groundwater sample from a deep part of the excavation.

\subsubsection{2001 Results and Issues}

Two downgradient groundwater monitoring wells were installed in 2000 to identify whether chemicals had migrated in groundwater. No PCBs have been detected in these wells, but groundwater from one well has been found to contain a low level of 1,1-dichlorethane. Two additional wells were installed at the site in 2001 to better define the extent of VOCs and PCBs in groundwater. Low levels of hydraulic oil were detected but no PCBs or VOCs.

\subsubsection{IR-6 and IR-8 Drainage Channels}

\subsubsection{Background}

Surface water runoff from the Research Yard drains into the manmade IR-6 drainage channel, and ultimately off site into San Francisquito Creek.

IR-8 is a natural ephemeral drainage that was engineered during SLAC construction to accept groundwater from the linac subdrainage system and surface water runoff from the campus area at SLAC. 
In 1992, soil and sediment samples were taken along a 2.5 mile length of San Francisquito Creek. The samples analyzed for a variety of constituents and analysis results showed no detectable PCBs. Lead analysis showed only background levels.

Additional study of the drainage system, the removal and off-site disposal of chemically impacted sediments from the IR-6 off site drainage channel, and its upstream catch basins occurred in 1995. The RWQCB was the lead agency.

In 1997, it was found that sediments with PCBs were still entering the IR-6 drainage channel. Video taping of the storm drain lines indicated sediment was trapped in the lines. This sediment in the storm drain lines was the presumed main source of residual PCB. In 1997, all removable solids were flushed out of the Research Yard drain lines.

In 2000, SLAC completed a draft human health and screening ecological risk assessment, as well as an initial feasibility study of clean-up options for the IR- 6 and IR- 8 drainage channels. The draft assessment identified data gaps that led to implementing a field program to collect additional data.

The human and ecological risk assessment evaluated potential risks to receptors under current and hypothetical future scenarios. The screening feasibility study of potential cleanup options determined that source control and sediment removal were the preferred options. Once the sources are controlled, sediment in the IR- 6 and IR- 8 drainage channels will undergo a final remediation.

\subsubsection{2001 Results and Issues}

In 2001, the stormdrain lines were cleaned, and sediment and debris were cleaned from of the paved area that drains into the stormdrain lines.

In addition, systems to trap sediment before it migrates into the channels were reviewed in FY02 and may be tested in FY03.

In 2001, samples were collected at 50-foot interval down the length of the IR- 6 and IR- 8 drainage channels. The concentrations were consistent with last year's monitoring results, which indicated that PCBS were present only in the upper reaches of the channel and have not migrated. Where present, PCBs are at or below last year's concentrations. Lead concentration in channel sediments were generally within background levels for this area.

\subsubsection{Research Yard Investigation and Remediation}

\subsubsection{Background}

Previously, a number of former substations had been remediated for PCBs in the Research Yard. In addition, an extensive further evaluation of the Research Yard indicated a few more potential sources. Additional work was required at three sites: former Substations 512 and 505, and the 1.0/1.5 Megawatt Power Supply (MWPS) and 5.8 MWPS. 


\subsubsection{2001 Results and Issues}

SLAC removed impacted material at the former Substation 512 and 505, and the 1.0/1.5 MWPS in 2001 with involvement from the EPA and the SMC/DHS.

In addition, lead and PCBs were found in sediment that had accumulated on the asphalt near buildings and equipment in the Research Yard. Cleaning of this accumulated sediment, for approximately $75 \%$ of the Research Yard, occurred in 2000. The remainder of the Research Yard was cleaned in 2001. The cleaning consisted of vacuuming up accumulated sediment and debris and then pressure-washing the asphalt.

\subsection{Quality Assurance}

The SLAC Restoration Program Quality Assurance Project Plan and the Standard Operating Procedures provide standards for investigation and review of all data collection and analysis. 


\section{A}

\section{Model for Potential Dose Assessment}

As described in Section 4.2 of this report, SLAC accelerator operations generate some radioactive substances as well as some ionizing radiation. Because of this, DOE Order 5400.5 requires that SLAC (and similar facilities) assess and report the maximum total effective dose equivalent that could potentially be received by a member of the public due to SLAC operations, and the collective effective dose equivalent that could potentially be received by the population living within 80 $\mathrm{km}$.

Chapter 4 of this report summarizes those assessments and Table 4-3 presents the results.

This Appendix provides further details on how the individual and collective doses were determined. (Throughout this section, we will use the word dose to mean effective dose equivalent.)

Humans and other species can receive ionizing radiation doses by:

- Breathing air that contains radioactive substances

- Eating food or drinking water that contains radioactive substances

- Direct exposure to radiation

Radiation can come from many sources. For example, radiation from events that occur in our sun or in outer space is responsible for part of the dose received by everyone on earth. Radiation is also emitted by some machines (for example x-ray units and particle accelerators). Additionally, radiation is emitted by both natural and artificially-produced radioactive substances.

The possible doses resulting from SLAC operations and potentially received by members of the public are very small. They are much smaller than the doses to members of the public that result from natural background radiation and significantly below all regulatory limits. Of the possible processes that could cause a dose to the public, direct exposure to radiation produced by SLAC accelerators accounts for almost all of that small dose (see Table 4-3 of this report).

Section 4.3 describes the monitoring used to measure the radiation present at the SLAC site boundary. Appendix $C$ shows the monitoring locations and also monitoring results. The remainder of this section will provide additional details on how these data were calculated and how they were used to arrive at:

- The calculated maximum dose that could be received by a member of the public due to SLAC operations.

- The calculated collective dose that could be received by the population living within $80 \mathrm{~km}$ due to SLAC operations.

The doses reported in Appendix $C$ are net doses. That is, each number shown is the dose recorded by the dosimeter during a known period of time less the dose previously determined for the location (adjusted for time period) at a time when SLAC accelerators were not running and not producing radiation. The subtracted number accounts for natural background radiation (radiation 
that is always present due to naturally radioactive substances in the soil or air and due to ionizing radiation from the sun and outer space).

Note that even when the location of measurement is the same, the dose rate from natural sources fluctuates upwards and downwards. Occasionally, a net dose data point will end up as less than zero (see Table C-1). This means that for the period in question, the sum of the radiation dose arising from SLAC operations (if any) and the dose from natural background was less than the previously measured dose from natural background at the same location.

To use the data in Table C-1 to calculate the possible dose to the public, SLAC determined how the radiation dose changes with distance from the boundary of SLAC.

Most of the high-energy accelerator laboratories have made measurements to determine the characteristic attenuation of radiation fields from their facilities. These measurements are unique to each facility because of design differences, types of machines, and the surrounding topography. SLAC has chosen to use a conservative formula to calculate the dose at distances other than the point of measurement.

Lindenbaum gave a method for evaluating radiation "skyshine," which assesses the amount of radiation that can bounce off the atmosphere to reach locations not on its original path. This method was later verified by Ladu using Monte Carlo techniques ${ }^{1}$.

Lindenbaum approximated the radiation falloff by $\mathrm{e}^{-} \mathrm{R} / \lambda$ $/ \mathrm{R}$ where $\mathrm{R}$ is distance in meters from the source and $\lambda=250 \mathrm{~m}$. This equation fits the SLAC data fairly well for neutron doses and is the one used to predict skyshine doses beyond our measuring stations (see Figure A-1). We also use this model to calculate the photon dose as a function of distance, in which case a $\lambda$ of $500 \mathrm{~m}$ is used in the Lindenbaum equation.

Potential direct radiation dose to maximally exposed member of the public: As noted in Section 4.3, during 2001 SLAC monitored direct radiation at about 30 locations for the purpose of determining the dose at the site boundary. The distance between the site boundary and the closest home or businesses varies from one boundary location to the next. The distance between a point on the site boundary and the primary source of SLAC-produced direct radiation at that point also varies from one boundary location to the next. As a result, determining the maximum dose that could have been received by a member of the public due to SLAC operations is not as simple as reviewing the 30 data points and selecting the highest net dose recorded for the year. To determine the maximum possible calculated dose that could have been received in 2001, SLAC used the following process.

1. Determined maximum possible potential net dose to member(s) of the public closest to SLAC boundary

- Determined the five closest locations of the general public to the facility.

- Evaluated the optically stimulated luminescent dosimeter (OSLD) data for monitoring stations nearest to these five locations.

- Determined the source of the radiation as seen by the OSLD station in each case.

- In each case, extrapolated the photon dose from the source to the general public using a conservative line source geometry ( $1 / \mathrm{R}$ relationship), if the source was radiation from the klystrons used along the length of the linear accelerator. (In locations where line- source geometry may not have been the most accurate, it was conservative.)

${ }^{1}$ Jenkins, Theodore M., Accelerator Boundary Doses and Skyshine, Health Physics, Vol. 27, 251-257 [1974]; Lindenbaum, S.J. Shielding of High Energy Accelerators, Ann. Rev. Nucl. Sci, 11, 213-258, [1961]; Ladu, et. al., Nucl. Instr. and Meth., 62, [1968]. 
- Extrapolated the potential high energy neutron or photon dose from accelerator radiation using the Lindenbaum approximation described above.

2. Determined maximum possible potential net dose to member(s) of the public closest to locations of the highest-reading dosimeters on SLAC boundary

- Evaluated OSLD data to determine the five highest dose locations.

- Determined the location of the general public closest to these OSLD locations

- In each case, extrapolated the photon dose from the source to the general public using a conservative line source geometry ( $1 / \mathrm{R}$ relationship), if the source was klystron radiation. (In locations where the line source geometry may not have been accurate, it was conservative.)

- Extrapolated the potential neutron dose or photon dose from accelerator radiation using the Lindenbaum approximation.

3. Compared results from steps 1 and 2 and selected the calculated potential highest dose (and the associated location) from the two methods as the information to report for the maximally exposed individual.

Potential collective dose to the general public: To determine the potential collective dose (due to direct radiation from SLAC operations) that could be received by the population living within 80 $\mathrm{km}$ in 2001, SLAC used the following process:

1. Based on 1990 census date, established a population grid out to $80 \mathrm{~km}$ from the facility.

2. Determined the highest site boundary OSLD dose.

3. Made the conservative assumption that this dose was representative of the whole facility.

4. Applied this dose to the population grid using a line source geometry $(1 / \mathrm{R}$ relationship) out to 500 meters of the facility and a point source geometry $\left(1 / R^{2}\right.$ relationship) from 501 meters to 80,000 meters.

5. Extrapolated the potential neutron dose using the Lindenbaum approximation.

6. Summed all the population doses from the grid. 


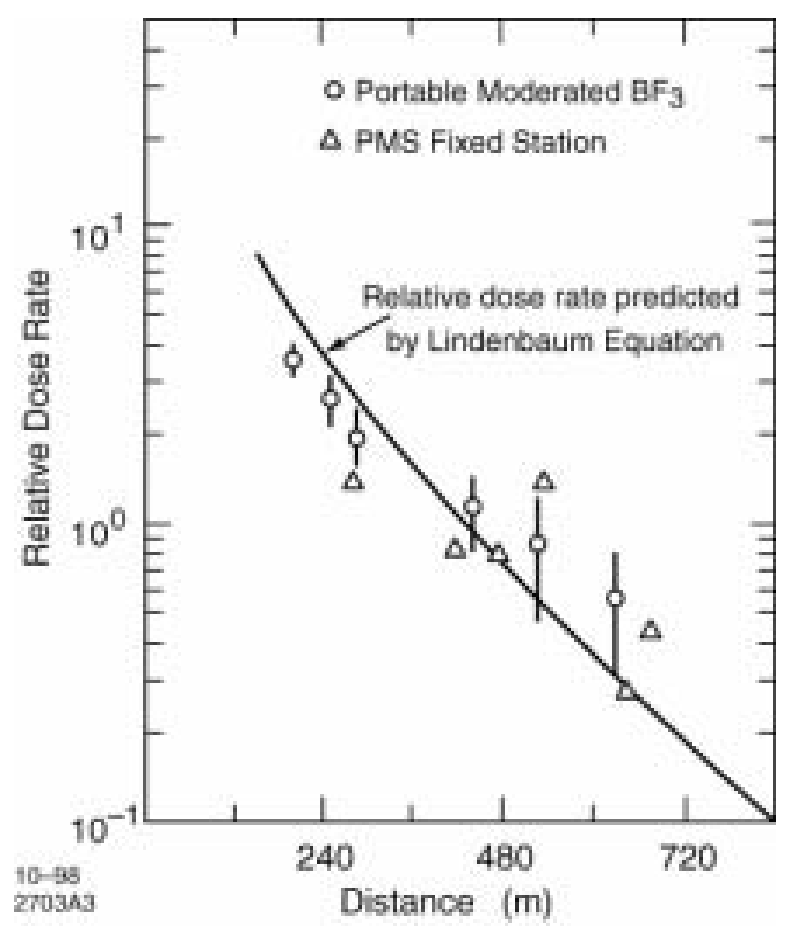

Figure A-1 Neutron Measurements Made Along a Line Between End Station A and the Site Boundary Note: The relative dose rate is normalized with respect to beam power. 


\section{Facility Information}

\subsection{Site Description}

\subsubsection{Location of site [40 CFR 61.94(b)(1)]}

Stanford Linear Accelerator Center (SLAC) is located at 2575 Sand Hill Road, Menlo Park, CA 94025. SLAC is a facility operated by Stanford University under contract with the U.S. Department of Energy (DOE). It is located on the San Francisco peninsula, about halfway between San Francisco and San Jose, California.

\subsubsection{Facilities and Purpose}

Since the sixties, facilities at SLAC have been used as resources for the U.S. and international high-energy physics research community. SLAC came into being with the construction of a 3.2 $\mathrm{km}$ ( 2 mile) long particle accelerator. Though this accelerator is now one of several linear accelerators at SLAC, it is the one known as the Linac. Currently, the Linac can accelerate electrons and positrons to a maximum energy of $50 \mathrm{GeV}$. As will be described in Section 2.2, electron and positron beams from the Linac are used for a number of different research purposes.

The Stanford Synchrotron Radiation Laboratory (SSRL) is also located on site and is operated by SLAC. This laboratory has its own accelerator and uses $3 \mathrm{GeV}$ electrons to generate synchrotron radiation (intense $\mathrm{x}$-ray beams). Synchrotron radiation is used for experiments in a wide variety of fields (biology, chemistry, geology, materials science, medicine, etc.) and SSRL attracts a steady stream of research teams.

Other facilities at SLAC are used to maintain the accelerators, to design and construct new detector systems, and to conduct research in accelerator technology. An active international research program conducts experiments to support the design and construction of an ultra-high energy particle accelerator. This future accelerator is known as the Next Linear Collider (NLC). The facilities used in this effort include a prototype accelerator, the Next Linear Collider Test Accelerator (NLCTA).

\subsection{Source Description} [40 CFR 61.94(b)(2),(3),(7)]

Radioactive material is inevitably produced by the operation of high-energy particle accelerators. During acceleration, some particles strike accelerator components and induce radioactivity in the material. Secondary radiation in the form of high-energy photons can also interact with materials. When highenergy photons interact with the nuclei present in air molecules, radionuclides such as ${ }^{15} \mathrm{O},{ }^{13} \mathrm{~N},{ }^{11} \mathrm{C}$, and ${ }^{41}$ Ar may be produced.

Radioactivity induced in accelerator components or in air is insignificant, except in areas where there is a major loss of beam power, such as at collimators, targets, or beam dumps. This is because, even when exposed to radiation with energy high enough to convert stable nuclei to radioactive nuclei, the probability of such a transformation is very low (small cross sections for the required reactions). Many of the radionuclides that are induced, very quickly decay to stable (non-radioactive) materials (short half lives). 
In a January 1998 letter to the Environmental Protection Agency (EPA), SLAC discussed the possibility of producing airborne radioactivity at SLAC in a number of ways: by escape from activated water, from loose contamination, and by machining of materials containing radioactivity. The letter concludes that, except for abnormal circumstances, the activation of air within accelerator housings is the only significant mode for production and emission of airborne radioactivity at SLAC.

There were no changes in processes during CY01 that would result in any of the other theoretical modes becoming a significant source of airborne radioactivity. The remainder of this report will address emissions from activation

\section{Air Emissions Data}

\subsection{Method Used to Determine Airborne Radioactivity Released During Year [40 CFR 61.93(b)(4) and 61.94(b)(2), (3), (5), (7)]}

\subsubsection{Emission Monitoring}

During a December 1997 meeting between representatives of EPA and SLAC, EPA questioned whether SLAC should be measuring the radioactivity in air emissions at some locations. SLAC responded to that issue in its January 1998 letter to EPA. SLAC noted that even based on its extremely conservative estimates of airborne radioactivity releases, SLAC sources are clearly in the category of minor release points. No release point at SLAC has the potential to discharge radioactivity into the air such that it could result in an effective dose equivalent (EDE) that exceeds $1 \%$ of the $10 \mathrm{mrem} / \mathrm{yr}$ standard. This conclusion means that the measurements described in 40 CFR 61.93(b)(1)-(3) are not required.

SLAC health physics personnel are the first to enter areas where radioactivity may be induced in air or accelerator components. In CY01, as in previous years, they measured radiation levels in such areas using portable radiation monitoring equipment. As noted in the SLAC's response to the EPA, the amounts of radioactivity SLAC estimates it releases from the emission points would lead to concentrations and dose rates that would be very obvious to such personnel. The fact that health physics personnel do not detect such dose levels upon entering these areas confirms that SLAC's release estimates are conservative.

If Linac operations make it reasonable to do so, SLAC health physics personnel will complete an additional type of confirmatory measurement of radioactivity in air during CY02 and will report the results in the next Annual Site Environmental Report.

\subsubsection{Calculations}

Section 2.2 will provide details specific to the calculations of activity vented to the atmosphere for each location identified as a possible release point at SLAC in CY01. The purpose of this section is to provide an overview of the assumptions and calculations used.

For CY01, there were nine locations in accelerator housings at SLAC with sufficient beam energy and where significant beam loss occurred so that air could have become activated. For several of the nine release points, we calculated the saturation activity for ${ }^{15} \mathrm{O},{ }^{13} \mathrm{~N},{ }^{11} \mathrm{C}$, and ${ }^{41} \mathrm{Ar}$. [The saturation activity is the activity that theoretically could be found at the instant of accelerator beam termination, if an accelerator had been operating consistently for a period that was long compared to the half-lives of the produced radionuclides.]

Each calculated saturation activity (reference: Radiological Safety Aspects of the Operations of Electron Linear Accelerators by William P. Swanson, IAEA, 1979) was based on:

- a geometric factor related to dimensions of the air volume in the accelerator housing that is associated with the release point, and

- the applicable beam power loss. 
For other release points, we estimated the saturation activity on some other basis. Where such an estimate was made, it is noted in the description for the release point; see Sections 2.2.1- 2.2.9 below.

For each of the nine release points, we determined the number of times during the year that potentially activated air associated with the release point was vented to the atmosphere. If the air volume was essentially sealed from the atmosphere, then the number of releases was set equal to the number of personnel entries into the particular area (this information is tracked during the year). In those cases where the potentially activated air wasn't sealed from the atmosphere and where air was released on an ongoing basis, we calculated the number of releases based on the rate of air changes per unit time for the volume of interest.

Regardless of whether the release of air from an area was ongoing or occurred in discrete events, we conservatively assumed that the air had always reached the saturation activity for each of the four radionuclides at a time before the air was vented to the atmosphere.

SLAC's Operational Health Physics (OHP) Department requires a cool-down period between termination of beam power and personnel entry into areas where there is major beam power loss. This delay in entry allows for decay of short-lived radionuclides induced in accelerator components and results in reduced personnel doses. The cool-down period is also effective in reducing the radionuclide concentrations in air that is released from sealed areas of the accelerator housing.

For those release points that corresponded to areas where the air was normally sealed, the released activities listed below are the saturation activities corrected for the decay that occurred during the cool-down period for that entry point. In each case, the cool-down period used in the CY01 calculation is listed in the column labeled "Typical Decay Time". In cases where the length of the cool down period varied during CY01, we were conservative and listed the shortest decay time as "typical".

We made the very conservative assumption that all of the calculated activity in air (saturation activities corrected for any applicable decay time) was released to the atmosphere each time a release occurred. We used this complete release assumption, although the venting of air from all areas was always passive (by diffusion) rather than active (use of fans).

In the descriptions of individual release points in Section 2.2, we included further details on the nature of the source. As noted in those descriptions, a few of the listed release points physically consisted of more than one point that we nonetheless elected to treat and a report as a single point. However, we treated such multiple points as a single release point only where that assumption was a conservative one, resulting in a "worst-case" dose estimate.

None of the release points were conventional stacks or vents and there were no devices installed to control the release of airborne radioactivity.

\subsection{Releases by Individual Source [40 CFR 61.94(b)(2), (3), (4), (6), (7)]}

\subsubsection{Accelerator Tunnel (Linac)}

The Linac is contained in a $3.2 \mathrm{~km}$ (2-mile) long tunnel located 7.6 meters ( $25 \mathrm{feet}$ ) below ground. There is relatively little beam loss in the Linac and few places where induced activity is likely to occur. However, beam loss does occur with beam collimation. The saturation activities in Table 1 are based on the following assumptions:

- Total power loss from beam interaction with collimators in the Linac is $<50 \%$ of the maximum power loss calculated to occur in the Stanford Linear Col- 
lider (SLC) beam dumps when these dumps are in use and the Linac is operating at maximum power.

- Given the previous estimate, we may use $50 \%$ of each saturation activity calculated for the SLC beam dumps as a conservative estimate for the saturation activity for each radionuclide that could be induced in air inside the accelerator tunnel

Table 1 Accelerator Tunnel (Linac) Activity

\begin{tabular}{|c|c|c|c|c|c|}
\hline Radionuclide & $\begin{array}{c}\text { Saturation } \\
\left.\text { Activity (Ci }{ }^{*}\right)\end{array}$ & $\begin{array}{c}\text { Estimated } \\
\text { Number of } \\
\text { Releases }\end{array}$ & $\begin{array}{c}\text { Typical } \\
\text { Decay Time } \\
\text { (min) }\end{array}$ & $\begin{array}{c}\text { Activity } \\
\text { Released } \\
\left(\mathbf{C i}^{*} / \mathbf{y}\right)\end{array}$ & $\begin{array}{c}\text { Percent of } \\
\text { Contribution }\end{array}$ \\
\hline${ }^{15} \mathrm{O}$ & $1.0 \mathrm{E}-01$ & 13 & 60 & $1.65 \mathrm{E}-9$ & $0.00 \%$ \\
\hline${ }^{13} \mathrm{~N}$ & $2.0 \mathrm{E}-02$ & 13 & 60 & $4.00 \mathrm{E}-03$ & $5.91 \%$ \\
\hline${ }^{11} \mathrm{C}$ & $3.0 \mathrm{E}-02$ & 13 & 60 & $5.03 \mathrm{E}-02$ & $74.35 \%$ \\
\hline${ }^{41} \mathrm{Ar}$ & $1.5 \mathrm{E}-03$ & 13 & 60 & $1.34 \mathrm{E}-02$ & $19.74 \%$ \\
\hline Total: & $1.5 \mathrm{E}-01$ & & & $6.76 \mathrm{E}-02$ & $100.00 \%$ \\
\hline
\end{tabular}

$* 1 \mathrm{Ci}=37 \mathrm{GBq}$

The accelerator tunnel is one of the areas that are normally sealed, with releases of air taking place only when there is a deliberate entry. Personnel reach the accelerator tunnel through $76-\mathrm{cm}$ (30 inch) diameter shafts that are spaced 100.5 meters (330 feet) apart over the length of the tunnel. When the covers to the shafts are open, these shafts serve as the air intake and exhaust points (passive only) for the accelerator tunnel.

The covers to the access shafts are interlocked with power to the accelerator and must be closed for the accelerator to operate. Access to the tunnel is delayed until the cool-down period has ended (at a minimum).

Air from the accelerator tunnel could be released from any of several different access shafts that are normally used during an accelerator tunnel entry. However, we make the conservative assumption that whenever an access shaft is opened, all the air and any airborne activity is released at the access shaft located on the south side of the Linac just east of the Sector 28 alcove. That shaft is both the one that is closest to an area normally occupied by members of the public and the one adjacent to a section of the Linac where there is a series of beam collimators. The distance between this designated release point for the accelerator tunnel and the nearest receptor is about 305 meters (1000 feet).

\subsubsection{Damping Rings (DR)}

There are two damping rings associated with the Linac. The rings are underground at Sector 1 (near the western end of the Linac). The electron damping ring is on the north side of the Linac and the positron ring is on the south side. Electrons and positrons are diverted to circulate through the rings, whose purpose is to reduce the transverse emittance of the electron and positron pulses. In particular, power losses occur at the points (bending magnets) where the beam is extracted and re-injected into the Linac. 
Table 2 Damping Rings (DR) Activity

\begin{tabular}{|c|c|c|c|c|c|}
\hline Radionuclide & $\begin{array}{c}\text { Saturation } \\
\text { Activity (Ci }{ }^{\star} \text { ) }\end{array}$ & $\begin{array}{c}\text { Estimated } \\
\text { Number of } \\
\text { Releases }\end{array}$ & $\begin{array}{c}\text { Typical } \\
\text { Decay Time } \\
\text { (min) }\end{array}$ & $\begin{array}{c}\text { Activity } \\
\text { Released } \\
\left.\text { (Ci }{ }^{*} / \mathbf{y}\right)\end{array}$ & $\begin{array}{c}\text { Percent of } \\
\text { Contribution }\end{array}$ \\
\hline${ }^{15} \mathrm{O}$ & $1.8 \mathrm{E}-02$ & 12 & 60 & $2.75 \mathrm{E}-10$ & $0.00 \%$ \\
\hline${ }^{13} \mathrm{~N}$ & $3.2 \mathrm{E}-03$ & 12 & 60 & $5.91 \mathrm{E}-04$ & $17.84 \%$ \\
\hline${ }^{11} \mathrm{C}$ & $6.0 \mathrm{E}-04$ & 12 & 60 & $9.28 \mathrm{E}-04$ & $28.05 \%$ \\
\hline${ }^{41} \mathrm{Ar}$ & $2.2 \mathrm{E}-04$ & 12 & 60 & $1.79 \mathrm{E}-03$ & $54.11 \%$ \\
\hline Total: & $2.2 \mathrm{E}-02$ & & & $3.31 \mathrm{E}-03$ & $100.00 \%$ \\
\hline
\end{tabular}

$* 1 \mathrm{Ci}=37 \mathrm{GBq}$

The air inside the damping rings is sealed from the outside atmosphere during times when beam is present. Each ring has an entrance door; these are interlocked to prevent entry into the area until termination of power. Access to the area is delayed until the cool-down period has ended. When an entrance door is open, air exchange is passive.

The two entrances to the area are relatively close together and are treated as a single release point. The distance from the release point to the nearest receptor is about 274 meters (900 feet).

\subsubsection{Positron Vault (PV)}

The positron vault is underground on the north side of the Linac at Sector 21. Power loss occurs in the positron vault when electrons are deflected out of the accelerator beam and when those electrons strike the positron target.

Table 3 Positron Vault (PV) Activity

\begin{tabular}{|c|c|c|c|c|c|}
\hline Radionuclide & $\begin{array}{c}\text { Saturation } \\
\text { Activity (Ci }\end{array}$ & $\begin{array}{c}\text { Estimated } \\
\text { Number of } \\
\text { Releases }\end{array}$ & $\begin{array}{c}\text { Typical } \\
\text { Decay Time } \\
\text { (min) }\end{array}$ & $\begin{array}{c}\text { Activity } \\
\text { Released } \\
\left(\mathbf{C i}^{\star} / \mathbf{y}\right)\end{array}$ & $\begin{array}{c}\text { Percent of } \\
\text { Contribution }\end{array}$ \\
\hline${ }^{15} \mathrm{O}$ & $1.4 \mathrm{E}+00$ & 11 & 60 & $1.96 \mathrm{E}-08$ & $0.00 \%$ \\
\hline${ }^{13} \mathrm{~N}$ & $3.0 \mathrm{E}-01$ & 11 & 60 & $5.08 \mathrm{E}-02$ & $8.10 \%$ \\
\hline${ }^{11} \mathrm{C}$ & $3.0 \mathrm{E}-01$ & 11 & 60 & $4.26 \mathrm{E}-01$ & $67.88 \%$ \\
\hline${ }^{41} \mathrm{Ar}$ & $2.0 \mathrm{E}-02$ & 11 & 60 & $1.51 \mathrm{E}-01$ & $24.03 \%$ \\
\hline Total: & $2.0 \mathrm{E}+00$ & & & $6.27 \mathrm{E}-01$ & $100.00 \%$ \\
\hline
\end{tabular}

$* 1 \mathrm{Ci}=37 \mathrm{GBq}$

The positron vault is separated from the accelerator tunnel by a thick concrete shield and is sealed from the outside atmosphere during Linac operation. An entrance door to the positron vault is the potential (passive) release point; this door is interlocked to prevent access to the area when the Linac is in use. Access to the area is delayed until the cool-down period has ended (at a minimum).

The distance from the positron vault door to the nearest receptor is about 640 meters (2100 feet). 


\subsubsection{Beam Switchyard (BSY)}

The Beam Switchyard (BSY) is an underground area where the beam emerges from the eastern end of the Linac and where all or portions of the beam may be sent in various directions: to the Final Focus Test Beam, to End Station A, or to the Asymmetric B-Factory (see descriptions of these facilities in sections below).

As always, the intent is to direct the electron and positron beams to the appropriate beamlines with as little power loss as possible. But power loss does occur and there is a possibility of induced activity in beam components and in air.

To be conservative, we assume that the total power loss and saturation activities that can occur in the BSY are the same as those for the accelerator tunnel

Table 4 Beam Switchyard (BSY) Activity

\begin{tabular}{|c|c|c|c|c|c|}
\hline Radionuclide & $\begin{array}{c}\text { Saturation } \\
\text { Activity (Ci }\end{array}$ & $\begin{array}{c}\text { Estimated } \\
\text { Number of } \\
\text { Releases }\end{array}$ & $\begin{array}{c}\text { Typical } \\
\text { Decay Time } \\
\text { (min) }\end{array}$ & $\begin{array}{c}\text { Activity } \\
\text { Released } \\
\left(\mathbf{C i}^{\star} / \mathbf{y}\right)\end{array}$ & $\begin{array}{c}\text { Percent of } \\
\text { Contribution }\end{array}$ \\
\hline${ }^{15} \mathrm{O}$ & $1.0 \mathrm{E}-01$ & 9 & 120 & $1.46 \mathrm{E}-18$ & 0 \\
\hline${ }^{13} \mathrm{~N}$ & $2.0 \mathrm{E}-02$ & 9 & 120 & $4.26 \mathrm{E}-05$ & $0.39 \%$ \\
\hline${ }^{11} \mathrm{C}$ & $3.0 \mathrm{E}-02$ & 9 & 120 & $4.49 \mathrm{E}-03$ & $41.33 \%$ \\
\hline${ }^{41} \mathrm{Ar}$ & $1.5 \mathrm{E}-03$ & 9 & 120 & $6.33 \mathrm{E}-03$ & $58.27 \%$ \\
\hline${ }^{T} \mathrm{Total}:$ & $1.5 \mathrm{E}-01$ & & & $1.09 \mathrm{E}-02$ & $100 \%$ \\
\hline
\end{tabular}

$* 1 \mathrm{Ci}=37 \mathrm{GBq}$

The air inside the BSY is sealed from the outside atmosphere during times when beam is present. There are two entrance doors to the BSY; these are interlocked to prevent access to the area until termination of power. Access to the area is delayed until the cool-down period has ended. The minimum decay time for the area is two hours. When an entrance door is open, air exchange is passive.

The two entrances to the area are relatively close together and can be treated as a single release point. The distance from this release point to the nearest receptor is about 457 meters (1500 feet).

\subsubsection{Final Focus Test Beam (FFTB)}

The Final Focus Test Beam (FFTB) facility extends out into the Research Yard in a direct line from the eastern end of the Linac. FFTB tests technology that is used to compress electron beam pulses and increase collision probabilities for application in future linear accelerator designs.

Power loss in FFTB with the potential to produce radioactive gases is due to beam collimation and steering. (The beam dump for the FFTB beamline has nearly all power loss occurring in a volume where there is no air available for activation.). 
Table 5 Final Focus Test Beam (FFTB) Activity

\begin{tabular}{|c|c|c|c|c|c|}
\hline Radionuclide & $\begin{array}{c}\text { Saturation } \\
\text { Activity (Ci }{ }^{\star} \text { ) }\end{array}$ & $\begin{array}{c}\text { Estimated } \\
\text { Number of } \\
\text { Releases }\end{array}$ & $\begin{array}{c}\text { Typical } \\
\text { Decay Time } \\
\text { (min) }\end{array}$ & $\begin{array}{c}\text { Activity } \\
\text { Released } \\
\left.\text { (Ci }{ }^{*} / \mathbf{y}\right)\end{array}$ & $\begin{array}{c}\text { Percent of } \\
\text { Contribution }\end{array}$ \\
\hline${ }^{15} \mathrm{O}$ & $1.2 \mathrm{E}-04$ & 6 & 60 & $9.16 \mathrm{E}-13$ & $0.00 \%$ \\
\hline${ }^{13} \mathrm{~N}$ & $2.1 \mathrm{E}-04$ & 6 & 60 & $1.94 \mathrm{E}-05$ & $9.96 \%$ \\
\hline${ }^{11} \mathrm{C}$ & $2.2 \mathrm{E}-04$ & 6 & 60 & $1.70 \mathrm{E}-04$ & $87.50 \%$ \\
\hline${ }^{41} \mathrm{Ar}$ & $1.2 \mathrm{E}-06$ & 6 & 60 & $4.93 \mathrm{E}-06$ & $2.53 \%$ \\
\hline Total: & $5.5 \mathrm{E}-04$ & & & $1.95 \mathrm{E}-04$ & $100.00 \%$ \\
\hline
\end{tabular}

$* 1 \mathrm{Ci}=37 \mathrm{GBq}$

The FFTB area is sealed from the outside atmosphere during operations, with the entrance door as the only potential (passive) release point. This door is interlocked to prevent access to the area when beam is present. Access to the area is delayed until the cool-down period has ended (at a minimum).

The distance from this facility to the nearest receptor is about 487 meters (1550 feet).

\subsubsection{End Station A / Beam Dump East (ESA / BDE)}

End Station A (ESA) is located in the Research Yard and is north of the eastern end of the Linac. It is used for fixed target experiments with electrons of up to $50 \mathrm{GeV}$. Essentially all the power loss occurs at Beam Dump East (BDE), where the beam collides with a 400-gallon water dump at the end of the beamline. BDE is located underground, at the end of a tunnel.

Table 6 End Station A / Beam Dump East (ESA / BDE) Activity

\begin{tabular}{|c|c|c|c|c|c|}
\hline Radionuclide & $\begin{array}{c}\text { Saturation } \\
\text { Activity }\left(\mathrm{Ci}^{*}\right)\end{array}$ & $\begin{array}{c}\text { Estimated } \\
\text { Number of } \\
\text { Releases }\end{array}$ & $\begin{array}{c}\text { Typical Decay } \\
\text { Time }(\mathrm{min})\end{array}$ & $\begin{array}{c}\text { Activity } \\
\text { Released }\left(\mathrm{Ci}^{\star} /\right. \\
\mathrm{y})\end{array}$ & $\begin{array}{c}\text { Percent of } \\
\text { Contribution }\end{array}$ \\
\hline${ }^{15} \mathrm{O}$ & $1.7 \mathrm{E}-04$ & 10 & 0 & $1.7 \mathrm{E}-03$ & $4.19 \%$ \\
\hline${ }^{13} \mathrm{~N}$ & $1.7-03$ & 10 & 0 & $1.7 \mathrm{E}-02$ & $41.87 \%$ \\
\hline${ }^{11} \mathrm{C}$ & $8.9 \mathrm{E}-04$ & 10 & 0 & $8.9 \mathrm{E}-03$ & $21.92 \%$ \\
\hline${ }^{41} \mathrm{Ar}$ & $1.3 \mathrm{E}-03$ & 10 & 0 & $1.3 \mathrm{E}-02$ & $32.02 \%$ \\
\hline Total: & $4.1 \mathrm{E}-03$ & & & $4.1 \mathrm{E}-02$ & $100.00 \%$ \\
\hline
\end{tabular}

$* 1 \mathrm{Ci}=37 \mathrm{GBq}$

BDE does not have active ventilation and the entrance door to the tunnel containing BDE is the only potential release point. This tunnel door is a gate and does not seal the air inside the tunnel. We assume continuous air diffusion to the outside atmosphere at a rate of approximately one tunnel volume per week. For 2001, we assumed there were 10 releases, since there was beam reaching BDE for only 10 weeks during the year.

Since air diffusion from the area is ongoing (no cool-down period before release), we did not correct the calculated saturation activity for decay. This is conservative, since there would be decay during the time required for the air in the tunnel to escape to the atmosphere. 
The distance from the BDE gate release point to the nearest receptor is about 457 meters (1500 feet).

\subsubsection{Asymmetric B-Factory (PEP-II)}

The Asymmetric B-Factory (PEP-II) consists of two independent underground storage rings, one stacked above the other. The high-energy ring is used to store $9 \mathrm{GeV}$ electrons and the lowenergy ring is used for $3.1 \mathrm{GeV}$ positrons. The positrons and electrons circulate in opposite directions. High-energy head-on collisions can occur in areas where the beams are directed onto intersecting paths.

Most of the power loss -- relevant to the possible activation of air -- occurs in the electron and positron beam dumps. The beam dumps for the two beams are located in areas designated as IR 8 and IR-10.

Table 7 Asymmetric B-Factory (PEP-II) Activity

\begin{tabular}{|c|c|c|c|c|c|}
\hline Radionuclide & $\begin{array}{c}\text { Saturation } \\
\left.\text { Activity (Ci }{ }^{*}\right)\end{array}$ & $\begin{array}{c}\text { Estimated } \\
\text { Number of } \\
\text { Releases }\end{array}$ & $\begin{array}{c}\text { Typical } \\
\text { Decay Time } \\
\text { (min) }\end{array}$ & $\begin{array}{c}\text { Activity } \\
\text { Released } \\
(\mathbf{C i} / \mathbf{y})\end{array}$ & $\begin{array}{c}\text { Percent of } \\
\text { Contribution }\end{array}$ \\
\hline${ }^{15} \mathrm{O}$ & $2.46 \mathrm{E}-03$ & 3696 & 0 & $9.1 \mathrm{E}+00$ & $27.98 \%$ \\
\hline${ }^{13} \mathrm{~N}$ & $4.63 \mathrm{E}-03$ & 3696 & 0 & $1.7 \mathrm{E}+01$ & $52.66 \%$ \\
\hline${ }^{11} \mathrm{C}$ & $4.92 \mathrm{E}-04$ & 3696 & 0 & $1.8 \mathrm{E}+00$ & $5.60 \%$ \\
\hline${ }^{41} \mathrm{Ar}$ & $1.21 \mathrm{E}-03$ & 3696 & 0 & $4.5 \mathrm{E}+00$ & $13.76 \%$ \\
\hline Total: & $8.8 \mathrm{E}-03$ & & & $3.2 \mathrm{E}+01$ & $100.00 \%$ \\
\hline
\end{tabular}

$* 1 \mathrm{Ci}=37 \mathrm{GBq}$

The PEP-II rings are not sealed off from the outside atmosphere. There is no active ventilation, and we assume continuous air diffusion to the outside atmosphere at a rate of approximately one complete air exchange every 2 hours.

Since air diffusion from the area is ongoing (no cool-down period before release), we did not correct the calculated saturation activity for decay. This is conservative, since there would be decay during the time required for the air in the facility escape to the atmosphere.

We also made the conservative assumption that all activated air from the PEP-II facility would be released from the location of IR-10. IR-10 is closer to the locations occupied by the public than IR 8.

The distance from the designated release point to the nearest receptor is about 427 meters (1400 feet).

\subsubsection{Stanford Synchrotron Radiation Laboratory (SSRL)}

As noted in Section 1.2, the Stanford Synchrotron Radiation Laboratory (SSRL) is not dependent on the Linac for its electron beam. It has three main components: a dedicated linear accelerator that supplies electrons, a $3 \mathrm{GeV}$ booster ring, and the Stanford Positron Electron Asymmetric Ring (SPEAR). Note that while SPEAR has retained its historical name (the ring was used in several discoveries that led to Nobel Prizes), it is no longer used for positron beams.

The SPEAR housing contains about 25 x-ray beam ports used by a variety of research teams. However, because the average energy of the emitted $\mathrm{x}$-rays is well below the threshold for inducing radioactivity, SPEAR itself is not a significant source of radioactive gases. By contrast, the 
power loss and energy of radiation emitted at injection and extraction points for the booster ring are sufficient to induce radioactivity in beam components and air.

Table 8 Stanford Synchrotron Radiation Laboratory (SSRL) Activity

\begin{tabular}{|c|c|c|c|c|c|}
\hline Radionuclide & $\begin{array}{c}\text { Saturation } \\
\text { Activity (Ci }\end{array}$ & $\begin{array}{c}\text { Estimated } \\
\text { Number of } \\
\text { Releases }\end{array}$ & $\begin{array}{c}\text { Typical Decay } \\
\text { Time (min) }\end{array}$ & $\begin{array}{c}\text { Activity } \\
\text { Released } \\
\left(\mathbf{C i}^{*} / \mathbf{y}\right)\end{array}$ & $\begin{array}{c}\text { Percent of } \\
\text { Contribution }\end{array}$ \\
\hline${ }^{15} \mathrm{O}$ & $3.7 \mathrm{E}-04$ & 20 & 60 & $9.41 \mathrm{E}-12$ & $0.00 \%$ \\
\hline${ }^{13} \mathrm{~N}$ & $7.0 \mathrm{E}-04$ & 20 & 60 & $2.15 \mathrm{E}-04$ & $37.18 \%$ \\
\hline${ }^{11} \mathrm{C}$ & $8.0 \mathrm{E}-05$ & 20 & 60 & $2.06 \mathrm{E}-04$ & $35.63 \%$ \\
\hline${ }^{41} \mathrm{Ar}$ & $1.2 \mathrm{E}-05$ & 20 & 60 & $1.57 \mathrm{E}-04$ & $27.19 \%$ \\
\hline${ }^{T} \mathrm{Total}:$ & $1.2 \mathrm{E}-03$ & & & $5.79 \mathrm{E}-04$ & $100.00 \%$ \\
\hline
\end{tabular}

$* 1 \mathrm{Ci}=37 \mathrm{GBq}$

The booster ring area is sealed from the outside atmosphere during operations, with the entrance door as the only potential (passive) release point. This door is interlocked to prevent access to the area when the ring is in use. Access to the area is delayed until the cool-down period has ended (at a minimum).

The distance from this release point to the nearest receptor is about 427 meters (1400 feet).

\subsubsection{Next Linear Collider Test Accelerator (NLCTA)}

As described in Section 1.2, the Next Linear Collider Test Accelerator (NLCTA) is a prototype accelerator that is used in ongoing international research. This research is in support of planned future construction of a very long ( 20-mile) linear accelerator known as the Next Linear Collider (NLC).

NLCTA is 42 meters long. It is used in testing technologies that will be needed for NLC. Power loss occurs as the accelerated electron beam is collimated and steered.

Table 9 Next Linear Collider Test Accelerator (NLCTA) Activity

\begin{tabular}{|c|c|c|c|c|c|}
\hline Radionuclide & $\begin{array}{c}\text { Saturation } \\
\text { Activity }\left(\mathrm{Ci}^{\star}\right)\end{array}$ & $\begin{array}{c}\text { Estimated } \\
\text { Number of } \\
\text { Releases }\end{array}$ & $\begin{array}{c}\text { Typical Decay } \\
\text { Time (min) }\end{array}$ & $\begin{array}{c}\text { Activity } \\
\text { Released }\left(\mathrm{Ci}^{*} /\right. \\
\mathrm{y})\end{array}$ & $\begin{array}{c}\text { Percent of } \\
\text { Contribution }\end{array}$ \\
\hline${ }^{15} \mathrm{O}$ & $2.5 \mathrm{E}-04$ & 8 & 30 & $7.0 \mathrm{E}-08$ & $34.45 \%$ \\
\hline${ }^{13} \mathrm{~N}$ & $3.8 \mathrm{E}-04$ & 8 & 30 & $1.1 \mathrm{E}-07$ & $53.00 \%$ \\
\hline${ }^{11} \mathrm{C}$ & $1.9 \mathrm{E}-05$ & 8 & 30 & $5.4 \mathrm{E}-09$ & $2.65 \%$ \\
\hline${ }^{41} \mathrm{Ar}$ & $7.1 \mathrm{E}-05$ & 8 & 30 & $2.0 \mathrm{E}-08$ & $9.90 \%$ \\
\hline Total: & $7.2 \mathrm{E}-04$ & & & $2.0 \mathrm{E}-07$ & $100.00 \%$ \\
\hline
\end{tabular}

$* 1 \mathrm{Ci}=37 \mathrm{GBq}$

The NLCTA housing is sealed from the outside atmosphere during operations, with the entrance door as the only potential (passive) release point. This door is interlocked to prevent access to the area when NLCTA is in use. Access to the area is delayed until the cool-down period has ended (at a minimum). 
The distance from this release point to the nearest receptor is about 580 meters (1900 feet).

\subsubsection{Stanford Linear Collider (SLC)}

In CY01, there was no possible production of gaseous (or other) radioactivity and no release point associated with SLC. This is because SLAC has not used the SLC beamline since the summer of 1998. However, since SLAC anticipates future use of SLC, we have continued to include SLC in one of the tables used for this annual report (i.e. Table 12).

\section{Dose Assessments [40 CFR 61.94(b)(7)]}

\subsection{Description of Dose Model}

We used CAP88-PC Version 2 to calculate potential EDE to individuals and to the population from the estimated airborne radioactivity released by SLAC in CY01.

\subsection{Summary of Input Parameters}

\subsubsection{Input Data Used in General}

Regardless of whether calculating possible individual or collective EDE, meteorological data were required. For this purpose, we used the meteorological data provided for San Francisco Airport (SFO).

SLAC's basis for using the SFO data is one of the subjects described in detail in the January 1998 letter from SLAC to the Environmental Protection Agency (EPA). As shown in the letter, calculating EDE using SFO data instead of SLAC data cannot result in errors of significance. If SLAC were a different sort of facility with significant releases of airborne radioactivity, the situation could be different. However, with emissions extremely low, the EDEs calculated by CAP88 remain extremely small, regardless of which set of meteorological factors is used.

CAP88 also requires information on stack height and diameter. We specified that all releases of airborne radioactivity at SLAC took place from ground-level point sources, that is from stacks with heights and diameters of 0 meters.

\subsubsection{Input Specific to Determination of Maximum Possible EDE to an Individual}

Section 2.2 listed the nine release points for airborne radioactivity in CY01. For each point, we noted the distance between that release point and the nearest residence, or school, or business, etc. [per 40 CFR 61.94(b)(6)]. We considered the hypothetical member of the public at each such a location to be the Maximally Exposed Individual (MEI) associated with the particular release point.

In order to determine the location and EDE of the hypothetical MEI, taking into account all the airborne radioactivity we estimated was released by SLAC in CY01, we used CAP88 per Section 3.2.1 with the following additional input data:

- The estimated airborne radioactivity releases for each release point as summarized in Table 11

- The location of the MEI identified for each release point relative to each other release point; see Table 12 for input data (as well as results of the MEI determination)

\subsubsection{Input and Assumptions Specific to Calculation of Collective Dose}

In determining the collective EDE to members of the public within $80 \mathrm{~km}$ of SLAC, we used CAP88 per Section 3.2.1 with the following additional assumptions and input data: 
- We assumed all the airborne radioactivity -- that we estimated was released by SLAC in CY01 (summary data in Table 11) - was released from a single point near the center of SLAC (Sector 30).

- We used the population grid shown in Table 13. We assembled this grid by multiplying the area of each of the 208 geographic segments by the population density of the corresponding city/cities. Where segments included unpopulated areas (e.g. ocean), this was taken into account. We used 1990 census data to assemble this table.

\subsection{Compliance Assessment}

\subsubsection{Effective Dose Equivalent (EDE) and Location for Maximally Exposed Individual (MEI)}

Based on conservative estimates, the effective dose equivalent to the maximally exposed individual due to releases of airborne radioactivity at SLAC in CY01 was 0.08 mrem $\left(8 \times 10^{-4} \mathrm{mSv}\right)$.

The location that corresponds to the highest calculated EDE for releases in CY01 is on the north side of Sand Hill Road, slightly to the east of main entrance to SLAC.

\subsubsection{Collective Dose Equivalent (CEDE) to Population within $80 \mathrm{~km}$ of SLAC}

There is no standard for the CEDE to the population within $80 \mathrm{~km}$ of the facility, so the CEDE reported below is not a compliance issue. The CEDE is included in this section because it makes sense to group the results of our dose evaluations in a single portion of this report.

Based on conservative estimates, the collective effective dose equivalent (CEDE) to the population within $80 \mathrm{~km}$ of SLAC's site boundary $(4,917,433$ persons) due to releases of airborne radioactivity at SLAC in CY01was 0.23 person-rem $\left(2.3 \times 10^{-3}\right.$ person-Sv).

Table 10 Summary of CY01 EDE and CEDE due to Estimated Releases of Airborne Radioactivity

\begin{tabular}{|c|c|c|}
\hline Applies to: & Location: & Result: \\
\hline $\begin{array}{c}\text { maximally exposed individual } \\
\text { (MEI) }\end{array}$ & $\begin{array}{c}\text { north side of Sand Hill Road, slightly to the east } \\
\text { of main entrance to SLAC }\end{array}$ & $\begin{array}{c}0.08 \mathrm{mrem} \\
\left(8 \times 10^{-4} \mathrm{mSv}\right)\end{array}$ \\
\hline population & within 80 km of SLAC's site boundary & $\begin{array}{c}0.23 \text { person-rem } \\
\left(2.3 \times 10^{-3} \text { person-Sv }\right)\end{array}$ \\
\hline
\end{tabular}




\subsubsection{Certification \\ [40 CFR 61.94(b)(9)]}

I certify under penalty of law that I have personally examined and am familiar with the information submitted herein, and based on my inquiry of those individuals immediately responsible for obtaining the information, I believe that the submitted information is true, accurate and complete. I am aware that there are significant penalties for submitting false information including the possibility of fine and imprisonment. (See 18 U.S.C. 1001.)

Jenathan Dorfan

SLAC Director

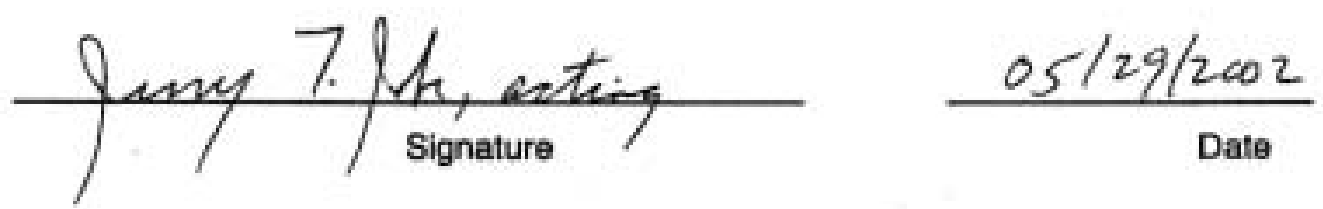

John S. Muhlestein

DOE Stanford Site Office Director
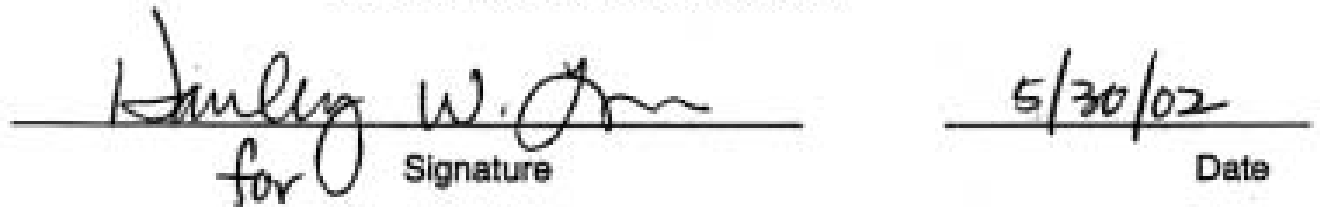


\section{Additional Information}

\subsection{Required Information [40 CFR 61.94(b)(8)]}

\subsection{1}

During CY01, there was no construction or modification of the type described in 40 CFR 61.94(b)(8).

\subsection{2}

During CY01, there were no unplanned releases of radionuclides to the atmosphere.

\subsection{3}

During CY01, there were no diffuse source emissions; release points consisted of the nine individual points identified in Section 2.2.

\subsection{Supplemental Information [DOE Guidance of 22 March 1994]}

\subsection{1}

Based on conservative estimates, the collective effective dose equivalent to the population within $80 \mathrm{~km}$ of SLAC's site boundary $(4,917,433$ persons) due to releases of airborne radioactivity at SLAC in CY01was 0.23 person-rem $\left(2.3 \times 10^{-3}\right.$ person-Sv).

\subsection{2}

Subparts Q and T of 40 CFR 61 did not apply to SLAC in CY01.

\subsection{3}

In CY01, SLAC did not possess sources containing ${ }^{232} \mathrm{U}$ or ${ }^{232} \mathrm{Th}$ where ${ }^{222} \mathrm{Rn}$ emissions could potentially exceed $0.1 \mathrm{mrem} / \mathrm{yr}$ to the public or $10 \%$ of the non-radon dose to the public.

\subsection{4}

In CY01, SLAC did not possess non-disposal/non-storage sources of ${ }^{222} \mathrm{Rn}$ emissions where emissions could potentially exceed $0.1 \mathrm{mrem} / \mathrm{yr}$ to the public or $10 \%$ of the nonradon dose to the public.

\subsection{5}

As discussed in Section 2.1.1, SLAC had no release points in CY01 that required continuous monitoring under 40 CFR 61.93(b)(4) 
Table 11 Summary Estimated Activity Released for CY01

\begin{tabular}{|c|c|c|c|c|c|c|c|c|c|c|c|}
\hline Radionuclide & $\begin{array}{c}\text { Accelerator } \\
\text { Tunnel } \\
{\left[\mathrm{Ci}^{*}\right]}\end{array}$ & $\begin{array}{c}\text { Dampin } \\
\text { g Rings } \\
{\left[\mathrm{Ci}^{\star}\right]}\end{array}$ & $\begin{array}{c}\text { Positron } \\
\text { Vault } \\
{\left[\mathrm{Ci}^{\star}\right]}\end{array}$ & $\begin{array}{c}\text { Beam } \\
\text { Switchy } \\
\text { ard }\left[\mathrm{Ci}^{\star}\right]\end{array}$ & $\begin{array}{l}\text { FFTB } \\
{\left[\mathrm{Ci}^{*}\right]}\end{array}$ & $\begin{array}{l}\text { ESA / } \\
\text { BDE } \\
{\left[\mathrm{Ci}^{\star}\right]}\end{array}$ & $\begin{array}{l}\text { PEP-II } \\
{\left[\mathrm{Ci}^{\star}\right]}\end{array}$ & $\begin{array}{l}\text { SSRL } \\
{\left[\mathrm{Ci}^{*}\right]}\end{array}$ & $\begin{array}{l}\text { NLCTA } \\
{\left[\mathrm{Ci}^{*}\right]}\end{array}$ & $\begin{array}{c}\text { All Site } \\
\text { Total } \\
{\left[\mathrm{Ci}^{\star}\right]}\end{array}$ & $\begin{array}{l}\text { Percent of } \\
\text { Contribution }\end{array}$ \\
\hline${ }^{15} \mathrm{O}$ & $1.7 \mathrm{E}-9$ & $2.7 \mathrm{E}-10$ & $2.0 \mathrm{E}-08$ & $1.5 \mathrm{E}-18$ & $9.2 \mathrm{E}-13$ & 1.7E-03 & $9.1 \mathrm{E}+00$ & $9.4 \mathrm{E}-12$ & 7.0E-08 & 9.1 & $27.35 \%$ \\
\hline${ }^{13} \mathrm{~N}$ & 4.0E-03 & $5.9 E-04$ & 5.1E-02 & 4.3E-05 & $1.9 \mathrm{E}-05$ & 1.7E-02 & $1.7 \mathrm{E}+01$ & $2.2 \mathrm{E}-04$ & $1.1 \mathrm{E}-07$ & 17.0 & $51.69 \%$ \\
\hline${ }^{11} \mathrm{C}$ & $5.0 \mathrm{E}-02$ & $9.3 E-04$ & 4.3E-01 & $4.5 \mathrm{E}-03$ & 1.7E-04 & 8.9E-03 & $1.8 \mathrm{E}+00$ & 2.1E-04 & 5.4E-09 & 2.3 & $6.95 \%$ \\
\hline${ }^{41} \mathrm{Ar}$ & 1.3E-02 & $1.8 \mathrm{E}-03$ & $1.5 \mathrm{E}-01$ & $6.3 \mathrm{E}-03$ & $4.9 \mathrm{E}-06$ & 1.3E-02 & $4.5 \mathrm{E}+00$ & $1.6 \mathrm{E}-04$ & $2.0 \mathrm{E}-08$ & 4.7 & $14.01 \%$ \\
\hline Total: & $6.8 \mathrm{E}-02$ & 3.3E-03 & 6.3E-01 & $1.1 \mathrm{E}-02$ & $1.9 \mathrm{E}-04$ & 4.1E-02 & $3.2 \mathrm{E}+01$ & $5.8 \mathrm{E}-04$ & $2.0 \mathrm{E}-07$ & 33.0 & \\
\hline $\begin{array}{l}\text { Percent of } \\
\text { Contribution }\end{array}$ & $0.20 \%$ & $0.01 \%$ & $1.89 \%$ & $0.03 \%$ & $0.0 \%$ & $0.12 \%$ & $97.74 \%$ & $0.00 \%$ & $0.00 \%$ & & $100.00 \%$ \\
\hline
\end{tabular}

$* 1 \mathrm{Ci}=37 \mathrm{GBq}$ 
Table 12 Determination of Maximally Exposed Individual

\begin{tabular}{|c|c|c|c|c|}
\hline $\begin{array}{l}\text { MEl for } \\
\text { which } \\
\text { source? }\end{array}$ & $\begin{array}{l}\text { Contributing } \\
\text { source }\end{array}$ & $\begin{array}{l}\text { MEI } \\
\text { location } \\
\text { relative to } \\
\text { source } \\
\text { (m) }\end{array}$ & $\begin{array}{l}\text { EDE from } \\
\text { source } \\
\text { (mrem/yr) }\end{array}$ & $\begin{array}{l}\text { Total EDE } \\
\text { for this MEI } \\
\text { (mrem/yr) }\end{array}$ \\
\hline LINAC & $\begin{array}{l}\text { LINAC } \\
\text { DR } \\
\text { PV } \\
\text { BSY } \\
\text { FFTB } \\
\text { ESA } \\
\text { PEP-II } \\
\text { SSRL } \\
\text { NLCTA } \\
\text { SLC }\end{array}$ & $\begin{array}{l}305 \mathrm{~N} \\
2438 \mathrm{ENE} \\
792 \mathrm{NE} \\
457 \mathrm{NW} \\
700 \mathrm{WNW} \\
670 \mathrm{WNW} \\
610 \mathrm{~W} \\
640 \mathrm{WNW} \\
820 \mathrm{WNW} \\
1280 \mathrm{WNW}\end{array}$ & $\begin{array}{c}5.20 \mathrm{E}-04 \\
2.70 \mathrm{E}-07 \\
2.70 \mathrm{E}-04 \\
2.10 \mathrm{E}-05 \\
6.10 \mathrm{E}-08 \\
1.50 \mathrm{E}-05 \\
8.00 \mathrm{E}-03 \\
2.50 \mathrm{E}-07 \\
9.40 \mathrm{E}-11 \\
0.00 \mathrm{E}+00\end{array}$ & \\
\hline & & & & 8.83E-03 \\
\hline 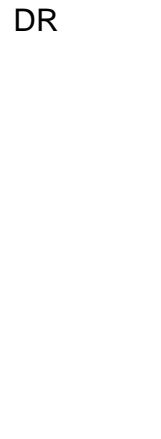 & $\begin{array}{l}\text { DR } \\
\text { LINAC } \\
\text { PV } \\
\text { BSY } \\
\text { FFTB } \\
\text { ESA } \\
\text { PEP-II } \\
\text { SSRL } \\
\text { NLCTA } \\
\text { SLC }\end{array}$ & $\begin{array}{l}274 \text { WNW } \\
2743 \text { W } \\
2195 \text { W } \\
3048 \text { W } \\
3353 \text { W } \\
3353 \text { W } \\
3440 \text { WSW } \\
3353 \text { W } \\
3600 \text { WSW } \\
3962 \text { W }\end{array}$ & $\begin{array}{c}9.60 \mathrm{E}-06 \\
9.60 \mathrm{E}-07 \\
1.50 \mathrm{E}-05 \\
2.10 \mathrm{E}-07 \\
1.20 \mathrm{E}-09 \\
4.10 \mathrm{E}-07 \\
1.30 \mathrm{E}-04 \\
5.50 \mathrm{E}-09 \\
6.10 \mathrm{E}-12 \\
0.00 \mathrm{E}+00\end{array}$ & 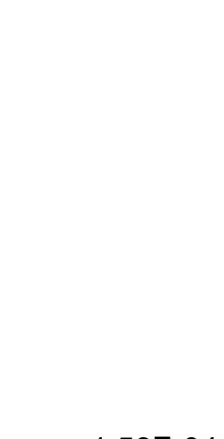 \\
\hline PV & $\begin{array}{l}\text { PV } \\
\text { LINAC } \\
\text { DR } \\
\text { BSY } \\
\text { FFTB } \\
\text { ESA } \\
\text { PEP-II } \\
\text { SSRL } \\
\text { NLCTA } \\
\text { SLC }\end{array}$ & $\begin{array}{l}640 \mathrm{NNE} \\
731 \mathrm{NNW} \\
2195 \mathrm{NE} \\
914 \mathrm{NW} \\
1157 \mathrm{NW} \\
1127 \mathrm{NW} \\
610 \mathrm{~W} \\
1097 \mathrm{NW} \\
820 \mathrm{WNW} \\
1676 \mathrm{NW}\end{array}$ & $\begin{array}{c}4.40 \mathrm{E}-04 \\
3.90 \mathrm{E}-05 \\
2.50 \mathrm{E}-07 \\
5.20 \mathrm{E}-06 \\
2.90 \mathrm{E}-08 \\
8.80 \mathrm{E}-06 \\
8.00 \mathrm{E}-03 \\
1.30 \mathrm{E}-07 \\
9.40 \mathrm{E}-11 \\
0.00 \mathrm{E}+00\end{array}$ & \\
\hline
\end{tabular}


Table 12 Determination of Maximally Exposed Individual (continued)

$$
\begin{aligned}
& \text { MEl for } \\
& \text { which } \\
& \text { Source? }
\end{aligned}
$$

BSY

FFTB

ESA

$\begin{array}{ll} & \begin{array}{l}\text { MEl location } \\ \text { relative to }\end{array} \\ \text { Contributing } & \begin{array}{l}\text { source } \\ \text { source }\end{array}\end{array}$

BSY

LINAC

DR

PV

FFTB

ESA

PEP-II

SSRL

NLCTA

SLC

FFTB
LINAC
DR
PV
BSY
ESA
PEP-II
SSRL
NLCTA
SLC

ESA

LINAC

DR

PV

BSY

FFTB

PEP-II

SSRL

NLCTA

SLC
457 NNW

366 NNW

2743 ENE

$640 \mathrm{NE}$

$700 \mathrm{NW}$

670 NW

$610 \mathrm{~W}$

640 NW

820 WNW

1280 WNW

$487 \mathrm{~N}$

$792 \mathrm{NE}$

3353 ENE

1554 NE

640 NNE

$457 \mathrm{~N}$

$427 \mathrm{~N}$

$427 \mathrm{~N}$

$580 \mathrm{~N}$

731 NW

$457 \mathrm{~N}$

$792 \mathrm{NE}$

3353 ENE

$1554 \mathrm{NE}$

640 NNE

$487 \mathrm{~N}$

427 NNE

$427 \mathrm{~N}$

$580 \mathrm{~N}$

731 NW

EDE from
Source
(mrem/yr)

Total EDE

for this MEI

(mrem/yr)

2.30E-05

1.70E-04

2.20E-07

4.30E-04

$9.70 \mathrm{E}-08$

2.50E-05

8.00E-03

4.10E-07

$9.40 \mathrm{E}-11$

$0.00 \mathrm{E}+00$

8.65E-03

4.90E-07

2.80E-05

1.50E-07

6.50E-05

$1.00 \mathrm{E}-05$

1.30E-04

8.20E-02

2.20E-06

2. $40 \mathrm{E}-10$

$0.00 \mathrm{E}+00$

8.22E-02

1.30E-04

2.80E-05

1.50E-07

6.50E-05

1.00E-05

$4.90 \mathrm{E}-07$

3.60E-02

2.20E-06

$2.40 \mathrm{E}-10$

$0.00 \mathrm{E}+00$ 
Table 12 Determination of Maximally Exposed Individual (continued)

\section{MEI for which Source?}

PEP-II

SSRL

NLCTA

SLC

SLC

LINAC

DR

PV

BSY

FFTB

ESA

PEP-II

SSRL

NLCTA

MEI location
relative to
source
(m)

427 NNE

$792 \mathrm{NE}$

3353 ENE

$1554 \mathrm{NE}$

640 NNE

$487 \mathrm{~N}$

$457 \mathrm{~N}$

$427 \mathrm{~N}$

580 NNW

$731 \mathrm{NW}$

$427 \mathrm{~N}$

$792 \mathrm{NE}$

$3353 \mathrm{ENE}$

$1554 \mathrm{NE}$

640 NNE

$487 \mathrm{~N}$

$457 \mathrm{~N}$

$427 \mathrm{~N}$

$580 \mathrm{~N}$

$731 \mathrm{NW}$

$580 \mathrm{NNW}$
$792 \mathrm{NE}$
$3353 \mathrm{ENE}$
$1554 \mathrm{NE}$
$640 \mathrm{NNE}$
$487 \mathrm{~N}$
$457 \mathrm{~N}$
$427 \mathrm{NNE}$
$427 \mathrm{~N}$
$731 \mathrm{NW}$

$731 \mathrm{NW}$

$274 \mathrm{NE}$
$1372 \mathrm{ENE}$
$3962 \mathrm{E}$
$2195 \mathrm{E}$
$1097 \mathrm{NE}$
$852 \mathrm{ENE}$
$822 \mathrm{ENE}$
$915 \mathrm{ENE}$
$792 \mathrm{ENE}$
$730 \mathrm{NE}$

$\begin{array}{ll}\begin{array}{l}\text { EDE from } \\ \text { Source } \\ \text { (mrem/yr) }\end{array} & \begin{array}{l}\text { Total EDE } \\ \text { for this MEI } \\ \text { (mrem/yr) }\end{array}\end{array}$

3.60E-02

2.80E-05

$1.50 \mathrm{E}-07$

6.50E-05

$1.00 \mathrm{E}-05$

4.90E-07

1.30E-04

2.20E-06

7.20E-11

$0.00 \mathrm{E}+00$

3.62E-02

2.20E-06

2.80E-05

$1.50 \mathrm{E}-07$

6.50E-05

$1.00 \mathrm{E}-05$

4.90E-07

1.30E-04

8.20E-02

$2.40 \mathrm{E}-10$

$0.00 \mathrm{E}+00$

8.22E-02

7.20E-11

2.80E-05

$1.50 \mathrm{E}-07$

6.50E-05

$1.00 \mathrm{E}-05$

4.90E-07

1.30E-04

3.60E-02

$2.20 \mathrm{E}-06$

$0.00 \mathrm{E}+00$

3.62E-02

$0.00 \mathrm{E}+00$

$1.20 \mathrm{E}-05$

2.20E- 07

9.20E-05

3.40E-06

$7.50 \mathrm{E}-08$

2.20E-05

8.20E-03

3.20E-07

$5.50 \mathrm{E}-11$ 


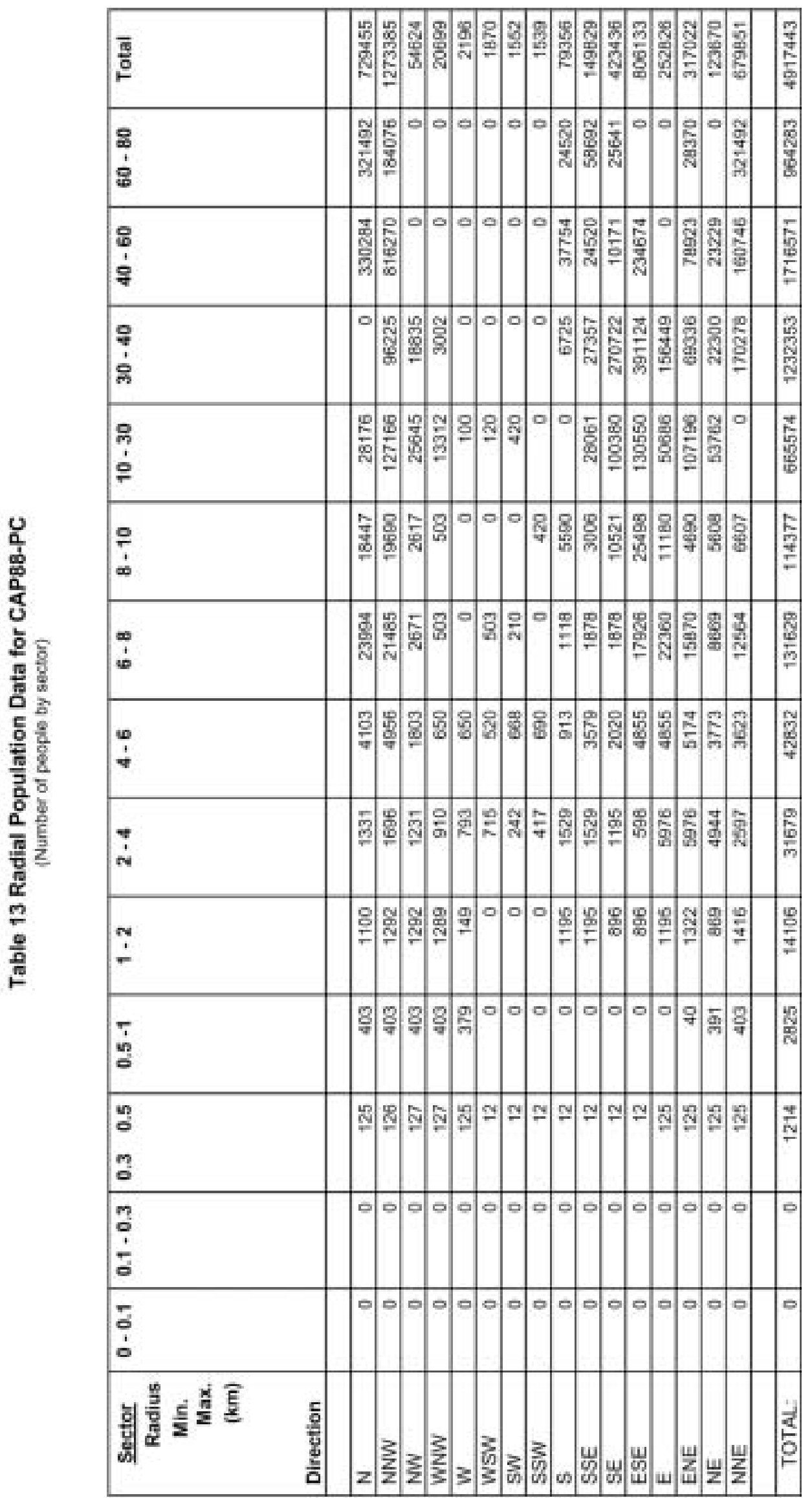




\section{Dosimeter Measurements for 2001}

This appendix contains data on environmental dosimeter measurements for 2001.

C-1 Summary of Net Photon and Neutron Doses for 2001

\begin{tabular}{l|c|c}
\hline \multicolumn{1}{c|}{ Dosimeter Type } & $\begin{array}{c}\text { Nominal Minimum } \\
\text { Detectable Levels }\end{array}$ & $\begin{array}{c}\text { Type of Radiation } \\
\text { Detected }\end{array}$ \\
\hline $\begin{array}{l}\mathrm{Al}_{2} \mathrm{O}_{3} \text { Luxel } \\
\text { (Landauer Company) }\end{array}$ & $1 \mathrm{mrem}$ & Photon \\
\hline $\begin{array}{l}\text { Neutrak } 144 \\
\text { (CR-39 Landauer Company) }\end{array}$ & $20 \mathrm{mrem}$ & Neutron \\
\hline
\end{tabular}

C-2 Environmental Dosimeters - Net Annual Doses for 2001

\begin{tabular}{|c|c|c|c|c|}
\hline ID \# & $\begin{array}{l}\text { Location } \\
\text { relative to } \\
\text { Linac }\end{array}$ & Location & $\begin{array}{l}\text { Net Photon Dose } \\
\text { (mrem) }\end{array}$ & $\begin{array}{l}\text { Net Neutron } \\
\text { Dose (mrem) }\end{array}$ \\
\hline $1 \mathrm{~A} \& \mathrm{~B}$ & & SB at Region 6 & $4+/-6$ & M \\
\hline $2 \mathrm{~A} \& \mathrm{~B}$ & $\mathrm{~W}$ of $\mathrm{SO}$ & SB at Injector & $4+/-6$ & M \\
\hline $3 \mathrm{~A} \& \mathrm{~B}$ & & Computer Center & $0+/-6$ & M \\
\hline $4 \mathrm{~A} \& \mathrm{~B}$ & & SB at Region 4 & $7+/-6$ & M \\
\hline $5 \mathrm{~A} \& \mathrm{~B}$ & $\mathrm{~N}, \mathrm{~S} 1$ & SB at N Damping Ring & $16+/-8$ & M \\
\hline $6 \mathrm{~A} \& \mathrm{~B}$ & $\mathrm{~S}, \mathrm{~S} 23$ & I-280 Overpass & $9+/-5$ & M \\
\hline 7A\&B & S, S10 & SB & $4+/-6$ & M \\
\hline $8 \mathrm{~A} \& \mathrm{~B}$ & & $\mathrm{SB}, \mathrm{B}$ of $\mathrm{A}$ & $9+/-6$ & M \\
\hline $9 A \& B$ & & Alpine Gate & $6+/-6$ & M \\
\hline $10 A \& B$ & & Meteorological Tower & $2+/-6$ & M \\
\hline $11 \mathrm{~A} \& \mathrm{~B}$ & & SB at SLD & $7+/-5$ & M \\
\hline $12 A \& B$ & & SB at Region 12 & $13+/-6$ & M \\
\hline
\end{tabular}


C-2 Environmental Dosimeters - Net Annual Doses for 2001

\begin{tabular}{|c|c|c|c|c|}
\hline ID \# & $\begin{array}{l}\text { Location } \\
\text { relative to } \\
\text { Linac }\end{array}$ & Location & $\begin{array}{c}\text { Net Photon Dose } \\
\text { (mrem) }\end{array}$ & $\begin{array}{l}\text { Net Neutron } \\
\text { Dose (mrem) }\end{array}$ \\
\hline $13 A \& B$ & & SB at Region 2 & $-3+/-5$ & $M$ \\
\hline $14 A \& B$ & & SLAC Entrance Gate & $9+/-6$ & M \\
\hline $15 A \& B$ & & SLAC Cafeteria & $13+/-5$ & M \\
\hline $16 A \& B$ & & SB at Region 8 & $0+/-6$ & M \\
\hline $17 A \& B$ & & SB at AW Bldg. & $4+/-6$ & $M$ \\
\hline $18 A \& B$ & $\mathrm{~N}, \mathrm{~S} 21$ & SB at Positron Vault & $8+/-6$ & $M$ \\
\hline $19 A \& B$ & & Bldg. 24 & $2+/-5$ & $M$ \\
\hline $20 A \& B$ & S, S20 & SB & $10+/-6$ & $M$ \\
\hline $21 A \& B$ & $S, S 1-2$ & SB at S Damping Ring & $4+/-6$ & $M$ \\
\hline $22 A \& B$ & N, S26-25 & E side 280 overpass & $7+/-6$ & $M$ \\
\hline $23 A \& B$ & $S, S 21-20$ & SB & $5+/-6$ & $M$ \\
\hline $24 A \& B$ & & SB Bldg. 81 & $3+/-6$ & $M$ \\
\hline $25 A \& B$ & & RAMSY Yard & $-10+/-6$ & $M$ \\
\hline $26 A \& B$ & & PMS1 & $11+/-6$ & M \\
\hline $27 A \& B$ & & PMS2 & $9+/-6$ & M \\
\hline $28 A \& B$ & & PMS3 & $14+/-6$ & M \\
\hline $29 A \& B$ & & PMS4 & $0+/-6$ & M \\
\hline $30 A \& B$ & & PMS5 & $4+/-5$ & M \\
\hline $31 \mathrm{~A} \& \mathrm{~B}$ & $\mathrm{~N}, \mathrm{~S} 21-20$ & PMS6 & $13+/-7$ & M \\
\hline $32 A \& B$ & & PMS7 & $4+/-5$ & $M$ \\
\hline $33 A \& B$ & $\mathrm{~N}, \mathrm{~S} 24$ & SB & $-4+/-6$ & $M$ \\
\hline $34 A \& B$ & $\mathrm{~N}, \mathrm{~S} 17$ & SB & $13+/-6$ & $M$ \\
\hline $35 A \& B$ & $\mathrm{~N}, \mathrm{~S} 5$ & SB & $36+/-8$ & $M$ \\
\hline
\end{tabular}

$\mathrm{E}=$ East

$\mathrm{N}=$ North

$\mathrm{S}=$ South

$\mathrm{W}=\mathrm{West}$
S\# = Linac sector \#

SB = SLAC site boundary

PMS = Peripheral Monitoring Station

$\mathrm{M}=$ below minimum detectable level
"Net Dose"

$=$ dose with background subtracted 


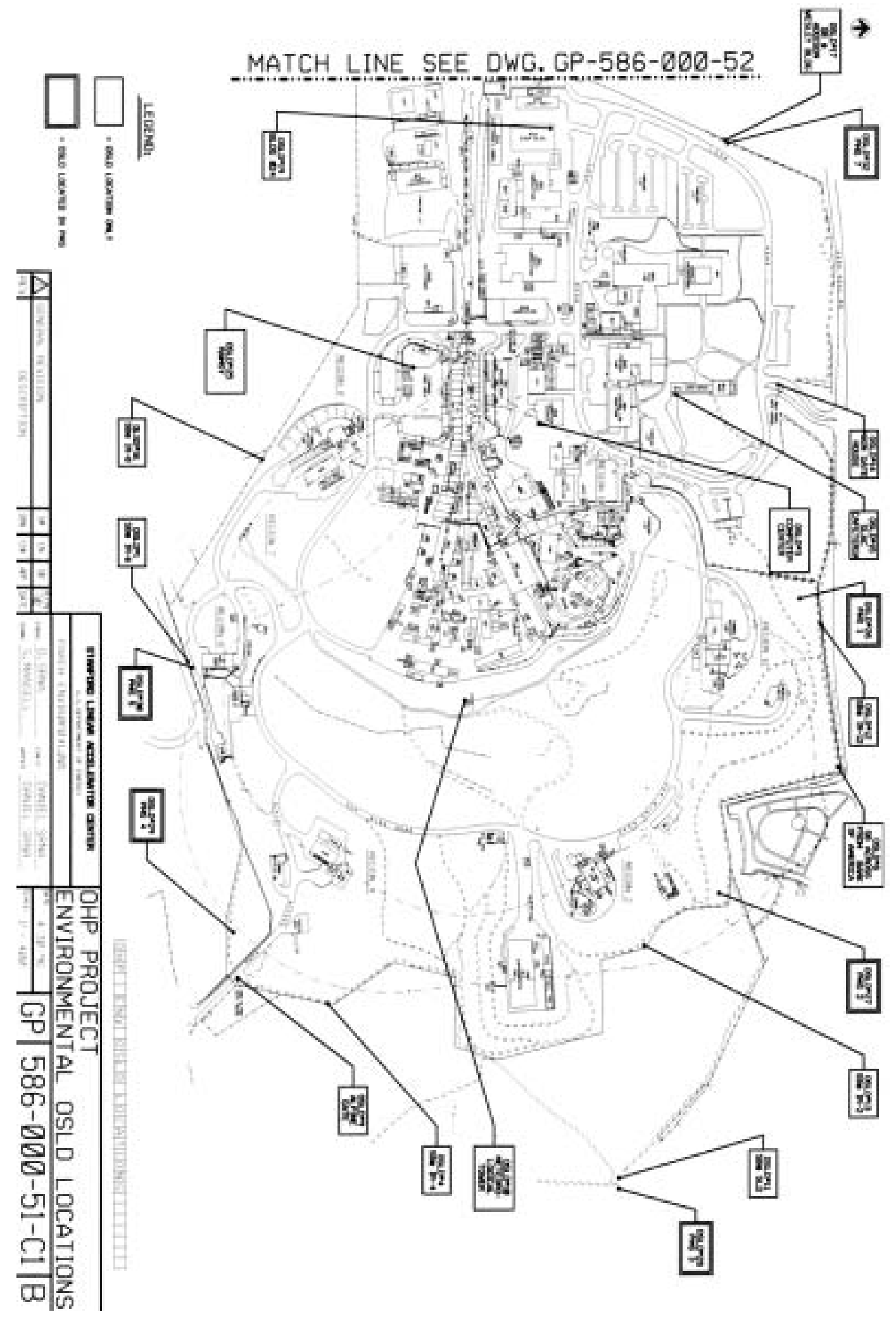

Figure C-1 Environmental OSLD Monitoring Stations, Sector 27 through SLC 


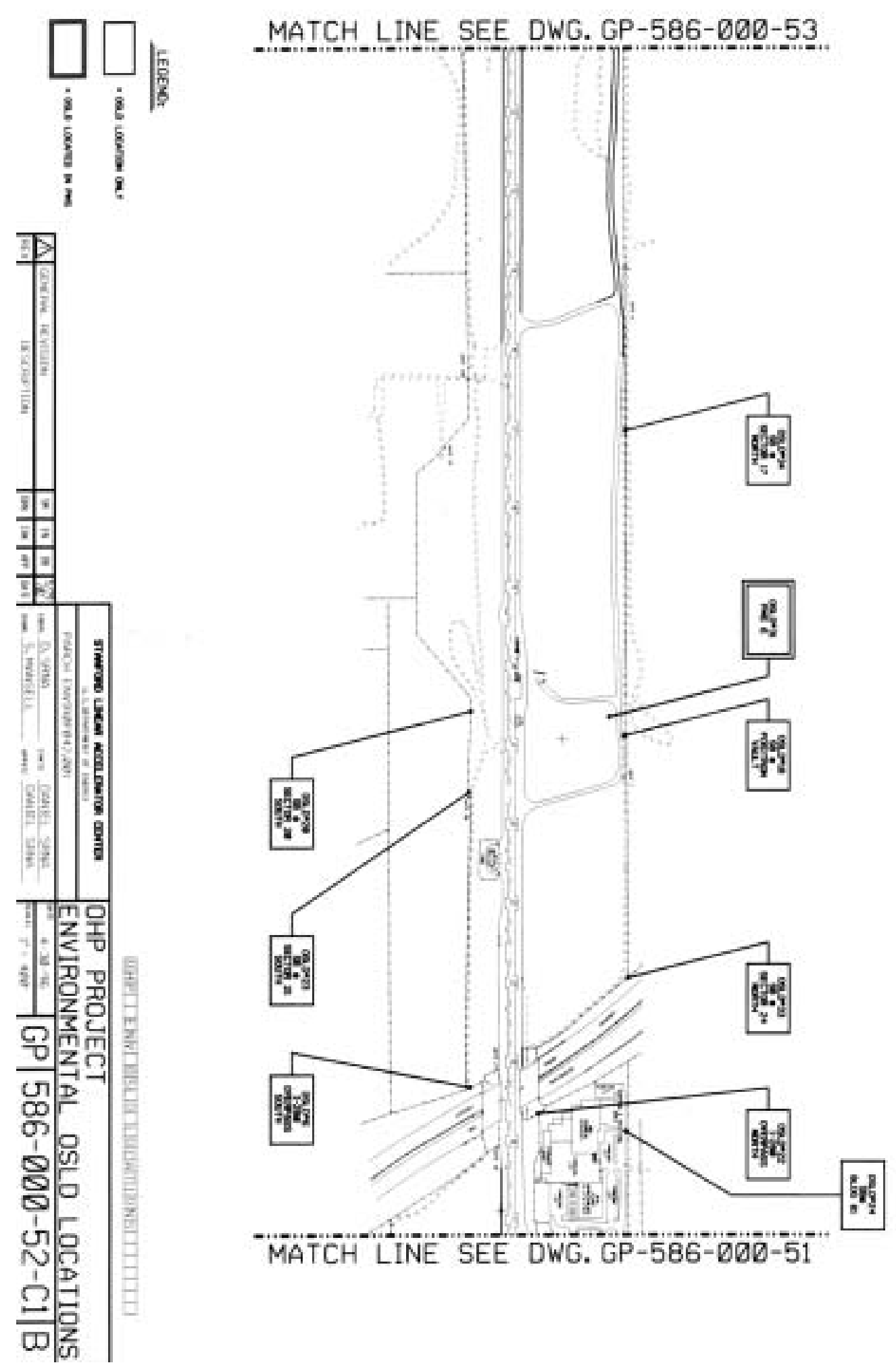

Figure C-2 Environmental OSLD Monitoring Stations, Sectors 12 through 27 


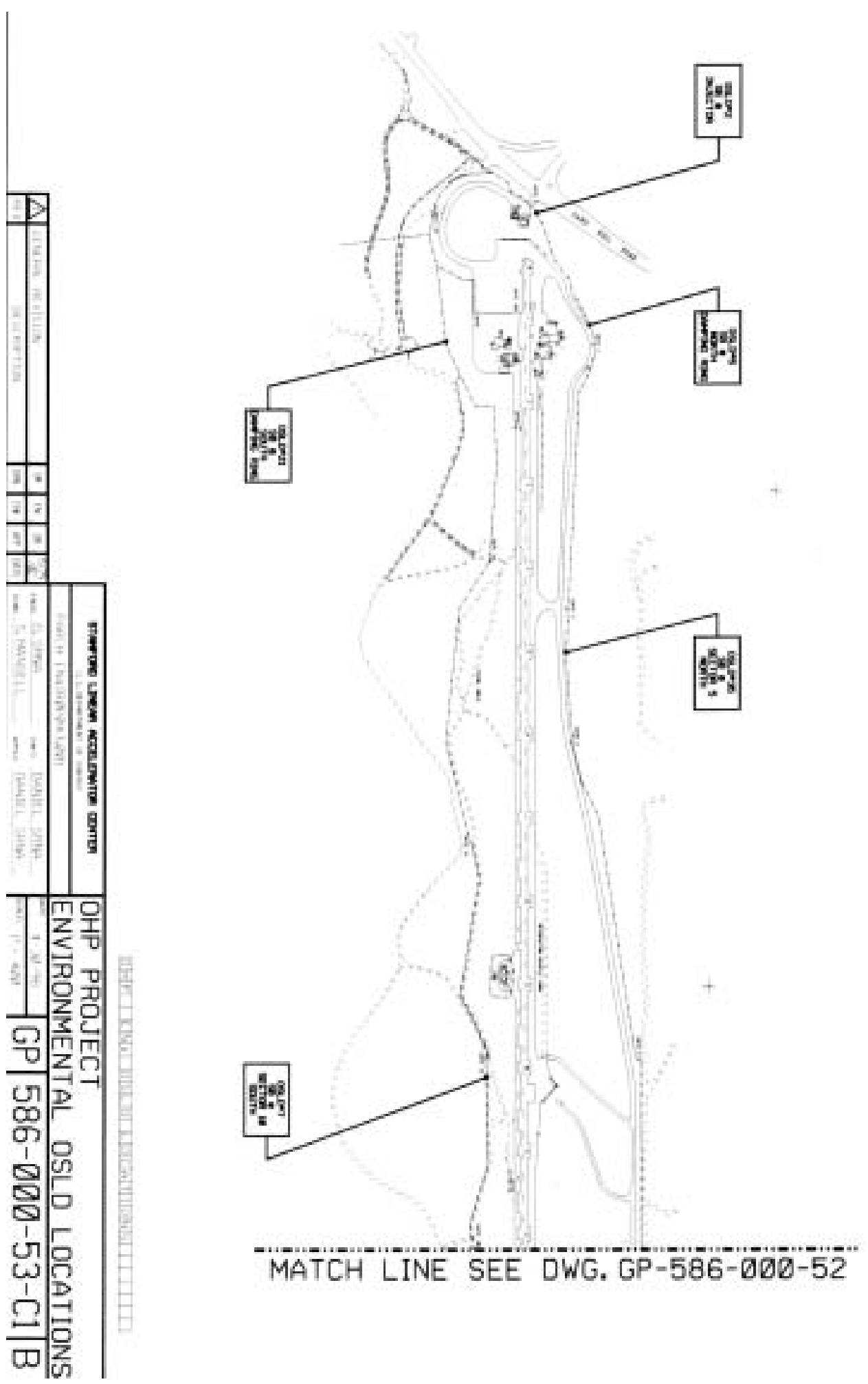

Figure C-3 Environmental OSLD Monitoring Stations, Sectors 0 through 12 


\section{Acronyms and Abbreviations}

A

ALARA As Low As Reasonably Achievable

ASER Annual Site Environmental Report

B

BAAQMD Bay Area Air Quality Management District

BDE

BMP

Beam Dump East

BPO

BSY

BTP

Best Management Practice

Basin Plan Objective

Beam Switchyard

Batch Treatment Plant

C

CAA Clean Air Act

CalARP California Accidental Release Prevention Program

CERCLA Comprehensive Environmental Response, Compensation, and Liability Act

CEQA California Environmental Quality Act

CWMA Centralized Waste Management Area

COE (Army) Corps of Engineers

CPM Counts Per Minute

CRMP Coordinated Resource Management and Planning (program)

CWA Clean Water Act

CX Categorical Exclusion

CY Calendar Year

D

DCE Dichloroethene

DCG Derived Concentration Guide

DEAR DOE Acquisition Regulations

DFG Department of Fish and Game

DOE Department of Energy

DOE/OAK DOE Oakland Operations Office

DOE/LAP DOE Laboratory Accreditation Process

DOE/SSO DOE Stanford Site Office 
E

EA Environmental Assessment

EC Electrical Conductivity

EDE Effective Dose Equivalent

EIS Environmental Impact Statement

EPA Environmental Protection Agency

EPCRA Emergency Planning and Community Right-to-Know Act

EML Environmental Measurements Laboratory

EMS Environmental Management System

EMSL-LV Environmental Monitoring Systems Laboratory- Las Vegas

EPR Environmental Protection and Restoration (Department)

ERP Environmental Restoration Program

ES\&H Environment, Safety, and Health (Division)

ESA $_{1} \quad$ Endangered Species Act

$\mathrm{ESA}_{2} \quad$ End Station A

ES\&HCC Environment, Safety, and Health Coordinating Council

$\mathbf{F}$

FEMA Federal Emergency Management Agency

FFS Final Focus System

FFTB Final Focus Test Beam

FHWSA Former Hazardous Waste Storage Area

FIFRA Federal Insecticide, Fungicide, and Rodenticide Act

FMS Flow Meter Station

FSUST Former Solvent Underground Storage Tank

FY Fiscal Year (October 1 - September 30)

G

GPMP Groundwater Protection Management Program

GPP General Plant Project

H

HMBP Hazardous Materials Business Plan

HPGe Hyper-pure Germanium

HWMC Hazardous Waste and Material Coordinator

HWMG Hazardous Waste Management Group

I

ISMS Integrated Safety Management System

IR Interaction Region

IRA Interim Removal Action

K

kWh kilowatt-hour 
$\mathbf{L}$

$\begin{array}{ll}\text { LA } & \text { Local Authority } \\ \text { LCW } & \text { Low Conductivity Water } \\ \text { linac } & \text { Linear Accelerator } \\ \text { LSC } & \text { Liquid Scintillation Counter }\end{array}$

M

MCC

MCL

MEI

MFD

M\&O

MPMWD

MW

\section{N}

NCP

NEPA

NESHAP

NHPA

NIST

NLC

NLCTA

NOI

NOV

$\mathrm{NO}_{\mathrm{X}}$

NPDES

NPL

NTC

NVLAP

0

ODS

OHP

OSLD

$\mathbf{P}$

PCB

$\mathrm{pCi} / \mathrm{I}$

PED

PEL

PEP

PEP-II

PMS

National Environmental Policy Act

National Historic Preservation Act

Next Linear Collider

Notice of Intent

Notice of Violation

Nitrogen Oxides

National Priorities List

Notice to Comply

Ozone-Depleting Substance

Polychlorinated Biphenyl

Pico-curies per Liter

Plant Engineering Department

Physical Electronics Laboratory

Positron-Electron Project

Asymmetric $B$ Factory

Peripheral Monitoring Station
Main Control Center

Maximum Concentration Level

Maximally Exposed Individual

Mechanical Fabrication Department

Management and Operating (Contractors) (a DOE designation)

Menlo Park Municipal Water Department

mega-watt

National (Oil and Hazardous Substances Pollution) Contingency Plan

National Emission Standards for Hazardous Air Pollutants

National Institute of Standards and Technology

Next Linear Collider Test Accelerator

National Pollutant Discharge Elimination System

National Voluntary Laboratory Accreditation Program

Operational Health Physics (Department)

Optically Stimulated Luminescent Dosimeter 


$\begin{array}{ll}\text { ppb } & \text { parts per billion } \\ \text { ppm } & \text { parts per million } \\ \text { POTW } & \text { Publicly Owned Treatment Works } \\ \text { PPO } & \text { Program Planning Office } \\ \text { PS } & \text { Positron Source }\end{array}$

$\begin{array}{ll}\text { Q } & \\ \text { QA } & \text { Quality Assurance } \\ \text { QAP } & \text { Quality Assessment Program } \\ \text { QC } & \text { Quality Control }\end{array}$

$\mathbf{R}$

RCRA Resource Conservation and Recovery Act

RI Remedial Investigation

RI/FS Remedial Investigation/Feasibility Study

RMP Risk Management Plan

ROI Return-on-Investment

RP Radiation Physics (Department)

RQ Reportable Quantity

RWQCB Regional Water Quality Control Board

RWTP Rinse Water Treatment Plant

$\mathrm{S}$

$\begin{array}{ll}\text { S\&E } & \text { Safety and Environmental } \\ \text { SARA } & \text { Superfund Amendments and Reauthorization Act } \\ \text { SBSA } & \text { South Bayside System Authority } \\ \text { SDWA } & \text { Safe Drinking Water Act } \\ \text { SEM } & \text { Site Engineering and Maintenance (Department) } \\ \text { SER } & \text { Site Environmental Report } \\ \text { SHA } & \text { Safety, Health, and Assurance (Department) } \\ \text { SLAC } & \text { Stanford Linear Accelerator Center } \\ \text { SLC } & \text { Stanford Linear Collider } \\ \text { SLD } & \text { SLAC Large Detector } \\ \text { SMC/DHS } & \text { San Mateo County Department of Health Services } \\ \text { SMS } & \text { Safety Management System } \\ \text { SPCC } & \text { Spill Prevention, Control, and Countermeasures Plan } \\ \text { SPEAR } & \text { Stanford Positron-Electron Asymmetric Ring } \\ \text { SSRL } & \text { Stanford Synchrotron Radiation Laboratory } \\ \text { Sv } & \text { Sievert } \\ \text { SWPPP } & \text { Storm Water Pollution Prevention Plan } \\ \text { T } & \\ \text { TCA } & \\ \text { TCE } & \text { Trichloroethane } \\ \text { TDS } & \text { Trichloroethene (or Trichloroethylene) }\end{array}$


TLD Thermoluminescent Dosimeter

TPH Total Petroleum Hydrocarbons

TRI Toxic Release Inventory

TSCA Toxic Substances Control Act

TSDF Treatment, Storage, and Disposal Facility

TSS Total Suspended Solids

TTO Total Toxic Organics

V

VOC

Volatile Organic Compound

W

WAA Waste Accumulation Area

WBSD West Bay Sanitary District

WSS Work Smart Standards

WM Waste Management (Department)

WTS Waste Tracking System 


\section{ASER Distribution}

Bay Area Air Quality Management District 939 Ellis Street

San Francisco, CA 94109

Fran Burton

Deputy Director

State of California

Radiological Health Branch

PO Box 942732

Sacramento, CA 95634-7320

Pat Dehmer

SC-10/Germantown Building

U.S. Department of Energy

1000 Independence Ave., S.W.

Washington, D.C. 20585-1290

Arnold Edelman

SC-83/Germantown Building

U.S. Department of Energy

1000 Independence Ave., S.W.

Washington, D.C. 20585-1290

Ross Natoli

Environmental Protection Specialist

EH-41/Forrestal Building

U.S. Department of Energy

1000 Independence Avenue, S.W.

Washington, D.C. 20585

Van Nguyen

SC-83/Germantown Building

U.S. Department of Energy

1000 Independence Ave., S.W.

Washington, D.C. 20585-1290

Dean Peterson

San Mateo Department of Health Services

Office of Environmental Health

455 County Center, $4^{\text {th }}$ Floor

Redwood City, CA 94063 
Glenn Podonsky

Director, Office of Independent Oversight \& Performance Assurance

OA-1/Germantown Building

U.S. Department of Energy

1000 Independence Ave., S.W.

Washington, D.C. 20585-1290

Michael Rochette

Regional Water Quality Control Board

San Francisco Bay Region

1515 Clay Street

Oakland, CA 94612

Silas D. Stadler

Deputy Assistant Secretary for Corporate Safety Assurance

EH-2/Germantown Building

U.S. Department of Energy

1000 Independence Ave., S.W.

Washington, D.C. 20585-1290

Walter Warnick

Director, Office of Scientific and Technical Information

SC-33/Germantown Building

U.S. Department of Energy

1000 Independence Ave., S.W.

Washington, D.C. 20585-1290

Christie Whitman

Administrator

Environmental Protection Agency/MC-3213A

Ariel Rios Building

1200 Pennsylvania Ave., N.W.

Washington, D.C. 20460 


\section{Annual Site Environmental Report Reader Survey}

\section{To Our Readers:}

Each Annual Site Environmental Report publishes the results of environmental monitoring at SLAC and documents our compliance with federal, state, and local environmental regulations. In providing this information, our goal is to give our readers (regulators, scientists, and the public) a clear accounting of our environmental activities, the methods we use, our results, the status of our program, and issues that affect SLAC environmental programs.

We want the information in this report to be of interest to you, easy to understand, and to communicate SLAC efforts to protect human health and the environment. We want to know from you if we succeeded. We appreciate and will use your comments to improve our next report.

1. Is the writing too concise? too verbose? uneven? just right?

2. Is the technical content too high? too low? just right?

3. Is the report comprehensive?

4. Do the tables and figures help you understand the text better?

Did you understand the tables and figures?

Are there too few figures?

Are there too many figures?

5. Are the data tables of interest?

Would you prefer short summaries of data trends instead of data tables?

6. Is the background information sufficient?

7. Did you understand the methods described?

8. Is the acronym list useful?

9. Are the appendices useful?

Other comments:

Please fold, staple, stamp, and mail this survey to SLAC.

Laboratory staff may return this survey via interoffice mail to ES\&H Writing Team Coordinator, Mailstop 84. 
Postage Required

ES\&H Writing Team Coordinator

Mailstop 84

Stanford Linear Accelerator Center

2575 Sand Hill Road

Menlo Park, CA 94025 